Prepared in cooperation with the New York City Department of Environmental Protection

\title{
Water-Quality Data From an Earthen Dam Site in Southern Westchester County, New York, 2015
}

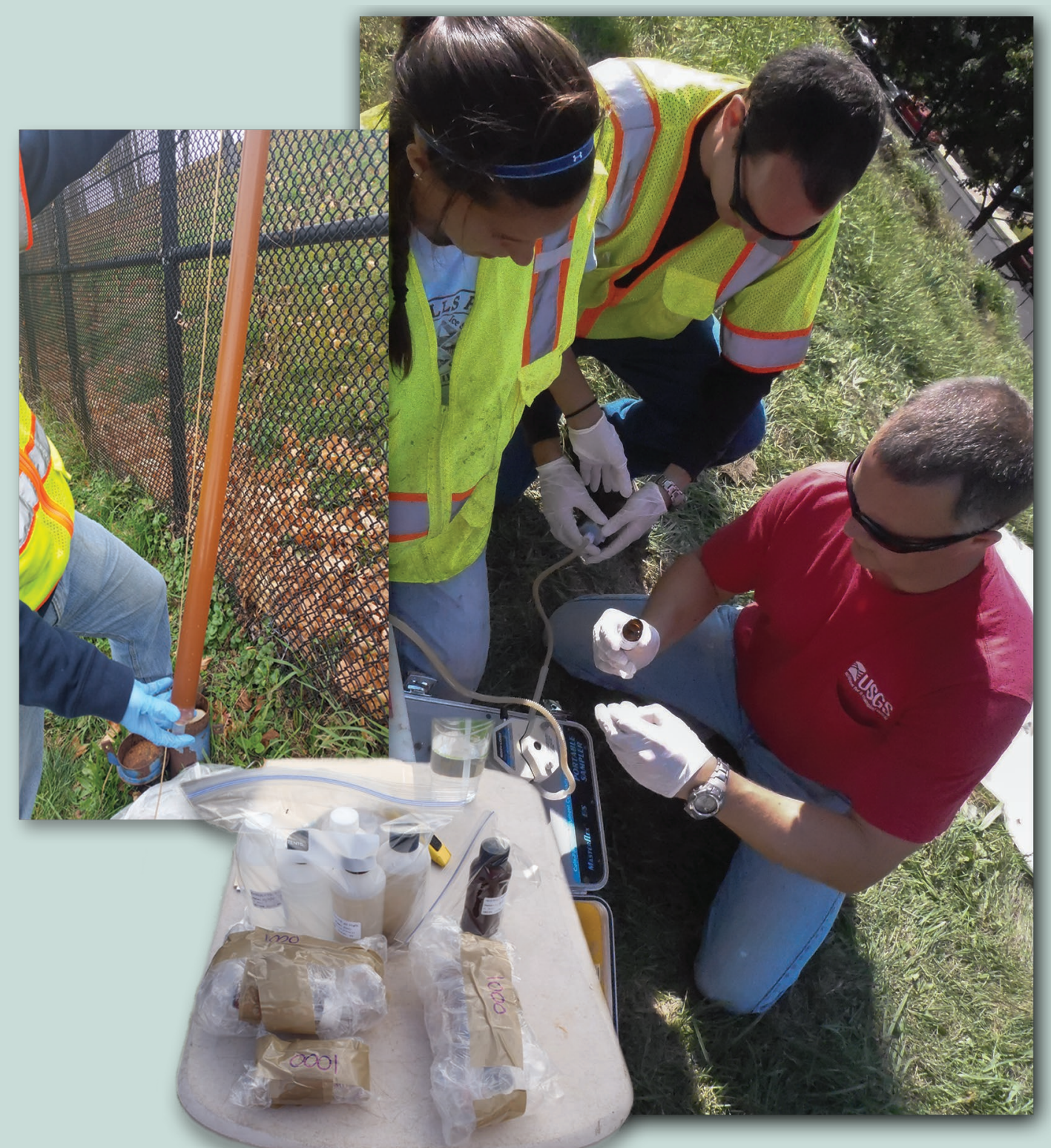

Data Series 1057

U.S. Department of the Interior

U.S. Geological Survey 


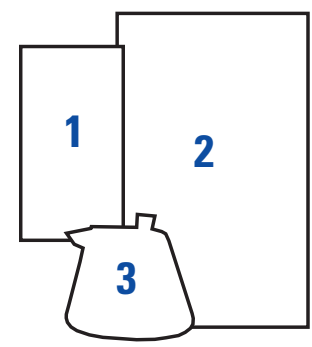

Cover. 1. USGS scientist collecting water sample from teflon bailer in Westchester County, NY. 2. USGS scientists collecting water sample from a low flow sampler in Westchester County, NY. 3. Packaging water samples for shipping in Westchester County, NY. 


\section{Water-Quality Data From an Earthen Dam Site in Southern Westchester County, New York, 2015}

By Anthony Chu and Michael L. Noll

Prepared in cooperation with the

New York City Department of Environmental Protection

Data Series 1057 


\title{
U.S. Department of the Interior \\ RYAN K. ZINKE, Secretary
}

\section{U.S. Geological Survey William H. Werkheiser, Acting Director}

\author{
U.S. Geological Survey, Reston, Virginia: 2017
}

For more information on the USGS - the Federal source for science about the Earth, its natural and living resources, natural hazards, and the environment-visit https://www.usgs.gov or call 1-888-ASK-USGS.

For an overview of USGS information products, including maps, imagery, and publications, visit https://store.usgs.gov.

Any use of trade, firm, or product names is for descriptive purposes only and does not imply endorsement by the U.S. Government.

Although this information product, for the most part, is in the public domain, it also may contain copyrighted materials as noted in the text. Permission to reproduce copyrighted items must be secured from the copyright owner.

Suggested citation:

Chu, Anthony, and Noll, M.L., 2017, Water-quality data from an earthen dam site in southern Westchester County, New York, 2015: U.S. Geological Survey Data Series 1057, 83 p., https://doi.org/10.3133/ds1057.

ISSN 2327-0271 (print) ISSN 2327-638X (online) ISBN 978-1-4113-4179-1 


\section{Acknowledgments}

The authors thank Richard Zunino, Will Melendez, and Masud Ahmed of the New York City Department of Environmental Protection for their technical assistance and logistical support. The authors also thank Michael D. Como from the U.S. Geological Survey for his technical, field, and logistical support during sample collection, and Kaitlyn M. Colella, Shawn Fisher, and Irene Fisher from the U.S. Geological Survey for their water-quality expertise and their logistical support in streamlining the data collection process. 



\section{Contents}

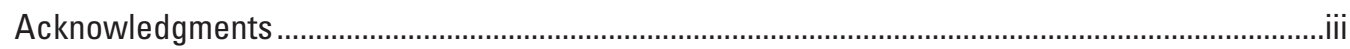

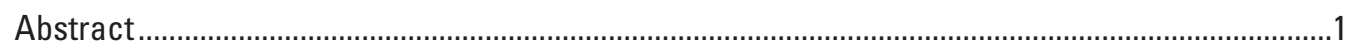

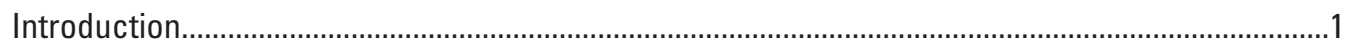

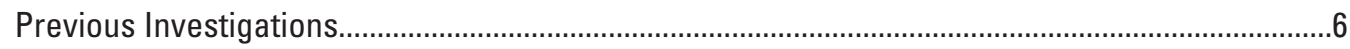

Methods of Water-Quality Sample Collection...........................................................................

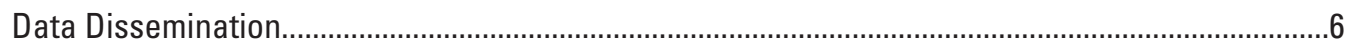

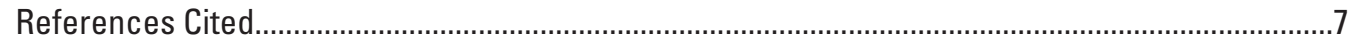

\section{Figures}

1. Map showing Hillview Reservoir study area and selected sites that were sampled for water quality, Westchester County, New York, 2015 ......................................2

2. Map showing sites that were sampled for water quality on the southern embankment at the Hillview Reservoir, Westchester County, New York, 2015 . .3

\section{Tables}

1. Site information for $A$, groundwater wells and $B$, East Basin, seep $A$, seep $E$, and manhole outflow at the Hillview Reservoir, Westchester County, New York, 2006 and 2015.

2. Concentrations of detected constituents in water samples collected from the Hillview Reservoir in Westchester County, New York, in 2015.

\section{Conversion Factors}

U.S. customary units to International System of Units

\begin{tabular}{lcl}
\hline \multicolumn{1}{c}{ Multiply } & \multicolumn{1}{c}{ By } & \multicolumn{1}{c}{ To obtain } \\
\hline inch (in.) & 25.4 & millimeter $(\mathrm{mm})$ \\
foot (ft) & 0.3048 & meter $(\mathrm{m})$ \\
gallon (gal) & 3.785 & liter $(\mathrm{L})$ \\
gallon (gal) & 0.003785 & cubic meter $\left(\mathrm{m}^{3}\right)$ \\
gallon (gal) & 3.785 & cubic decimeter $\left(\mathrm{dm}^{3}\right)$ \\
\hline
\end{tabular}

Temperature in degrees Celsius $\left({ }^{\circ} \mathrm{C}\right)$ may be converted to degrees Fahrenheit $\left({ }^{\circ} \mathrm{F}\right)$ as follows:

$$
{ }^{\circ} \mathrm{F}=\left(1.8 \times{ }^{\circ} \mathrm{C}\right)+32 .
$$




\section{Datum}

Vertical coordinate information is referenced to the National Geodetic Vertical Datum of 1929 (NGVD 29).

Horizontal coordinate information is referenced to the North American Datum of 1983 (NAD 83) Altitude, as used in this report, refers to distance above the vertical datum.

\section{Supplemental Information}

Specific conductance is given in microsiemens per centimeter at 25 degrees Celsius $(\mu \mathrm{S} / \mathrm{cm}$ at $\left.25^{\circ} \mathrm{C}\right)$.

Concentrations of chemical constituents in water are given in milligrams per liter $(\mathrm{mg} / \mathrm{L})$, nanograms per liter ( $\mathrm{ng} / \mathrm{L})$, or micrograms per liter $(\mu \mathrm{g} / \mathrm{L})$.

Activities for radioactive constituents in water are given in picocuries per liter ( $\mathrm{pCi} / \mathrm{L}$ ).

\section{Abbreviations}

NWOL National Water Quality Laboratory

NYCDEP New York City Department Environmental Protection

USGS U.S. Geological Survey 


\title{
Water-Quality Data From an Earthen Dam Site in Southern Westchester County, New York, 2015
}

\author{
By Anthony Chu and Michael L. Noll
}

\section{Abstract}

The U.S. Geological Survey, in cooperation with the New York City Department of Environmental Protection, sampled 37 sites in the reservoir area for nutrients, major ions, metals, pesticides and their degradates, volatile organic compounds, temperature, $\mathrm{pH}$, and specific conductance during fall 2015. Data collection was done to characterize the local groundwater-flow system and identify potential sources of seeps from the southern embankment at the Hillview Reservoir. Water-quality samples were collected in accordance with standard U.S. Geological Survey methods at 37 sites in and adjacent to Hillview Reservoir. These 37 sites were sampled to determine (1) baseline water-quality conditions of the saturated, low-permeability sediments that compose the earthen embankment that surrounds the reservoir, (2) water-quality conditions in the southwestern part of the study area in relation to the seeps on the embankment, and (3) temporal variation of water-quality conditions between 2006 and 2015 (not included in this report). The physical parameters and the results of the water-quality analysis from the 37 sites are included in this report and can be downloaded from the U.S. Geological Survey National Water Information System website.

\section{Introduction}

The Hillview Reservoir in southern Westchester County, New York, (fig. 1), constructed between 1913 and 1916, contains more than 900 million gallons of water, and maintains a hydrostatic head of about 293 feet (ft). Most of New York City's water passes through the Hillview Reservoir facility from the Kensico Reservoir, which is fed by the Delaware and Catskill aqueducts in upstate New York. Water is chlorinated at the reservoir and is piped from the southern end of the reservoir for distribution to users in the city. The partially concrete-lined reservoir, which has an area of about 90 acres, is equally divided into the East Basin and West Basin by a concrete dividing wall, and has operated continuously since the first water tunnel was completed in 1917. A 14-ft-diameter reinforced-concrete conduit (connecting conduit) hydraulically connects downtake chamber 1 to downtake chamber 2 (fig. 2; Malcolm Pirnie, Inc. and TAMS Consultants, Inc., 2002).

The embankment surrounding the reservoir is comprised of low-permeability glacial clays that were excavated from the site and placed on a veneer of low-permeability glacial deposits that overlie crystalline bedrock (Asselstine and Grossman, 1955; Baskerville, 1982, 1992). The southern embankment was subsequently modified by other construction and maintenance projects near the downtake, uptake, and control chambers; connecting shafts; connecting conduits; the reservoir dividing wall; and the bypass tunnel.

In fall 2015, the U.S. Geological Survey (USGS), in cooperation with the New York City Department of Environmental Protection, sampled 37 sites in the Hillview Reservoir. This sampling was done as an extension to a 2006 study to further investigate the hydrology of the embankment and determine the location of groundwater flows or seeps (table 1). This study was designed to determine (1) baseline waterquality conditions of the saturated, low-permeability sediments that compose the embankment that surrounds the reservoir basins, (2) water-quality conditions in the southwestern part of the reservoir in relation to the seeps on the embankment, and (3) for a temporal comparison of water-quality conditions between 2006 and 2015 (not included in this report).

Groundwater generally flows outward from the reservoir, through the low-permeability embankment, toward the surrounding glacial drift. Since 1999, several seeps downslope from the East Basin have flowed out from the western side of the southern embankment which is the steepest slope in the Hillview Reservoir (fig. 2). This report presents the waterquality data collected by the USGS from 37 sites surrounding the Hillview Reservoir, including water from the East Basin to delineate baseline water-quality conditions in the earthen embankment surrounding the reservoir. The USGS sampled every available site of the reservoir, and at the reservoir for nutrients, major ions, metals, pesticides, pesticide degradates, volatile organic compounds, temperature, $\mathrm{pH}$, and specific conductance. The water-quality data was collected, in addition to other basic hydrologic data, to further investigate the hydrogeologic framework of the southern embankment to determine possible sources of seeps. 


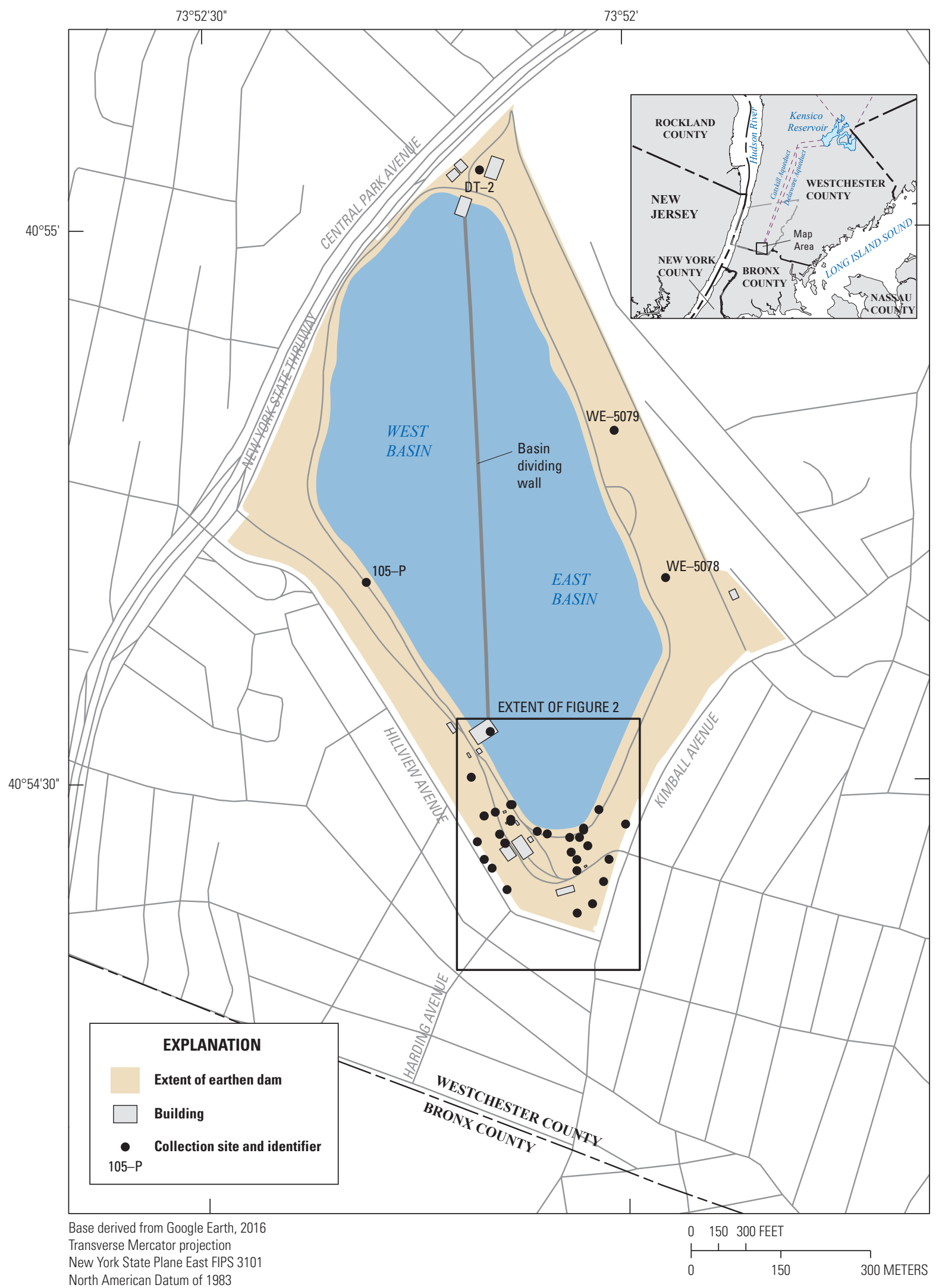

Figure 1. Hillview Reservoir study area and selected sites that were sampled for water quality, Westchester County, New York, 2015. 


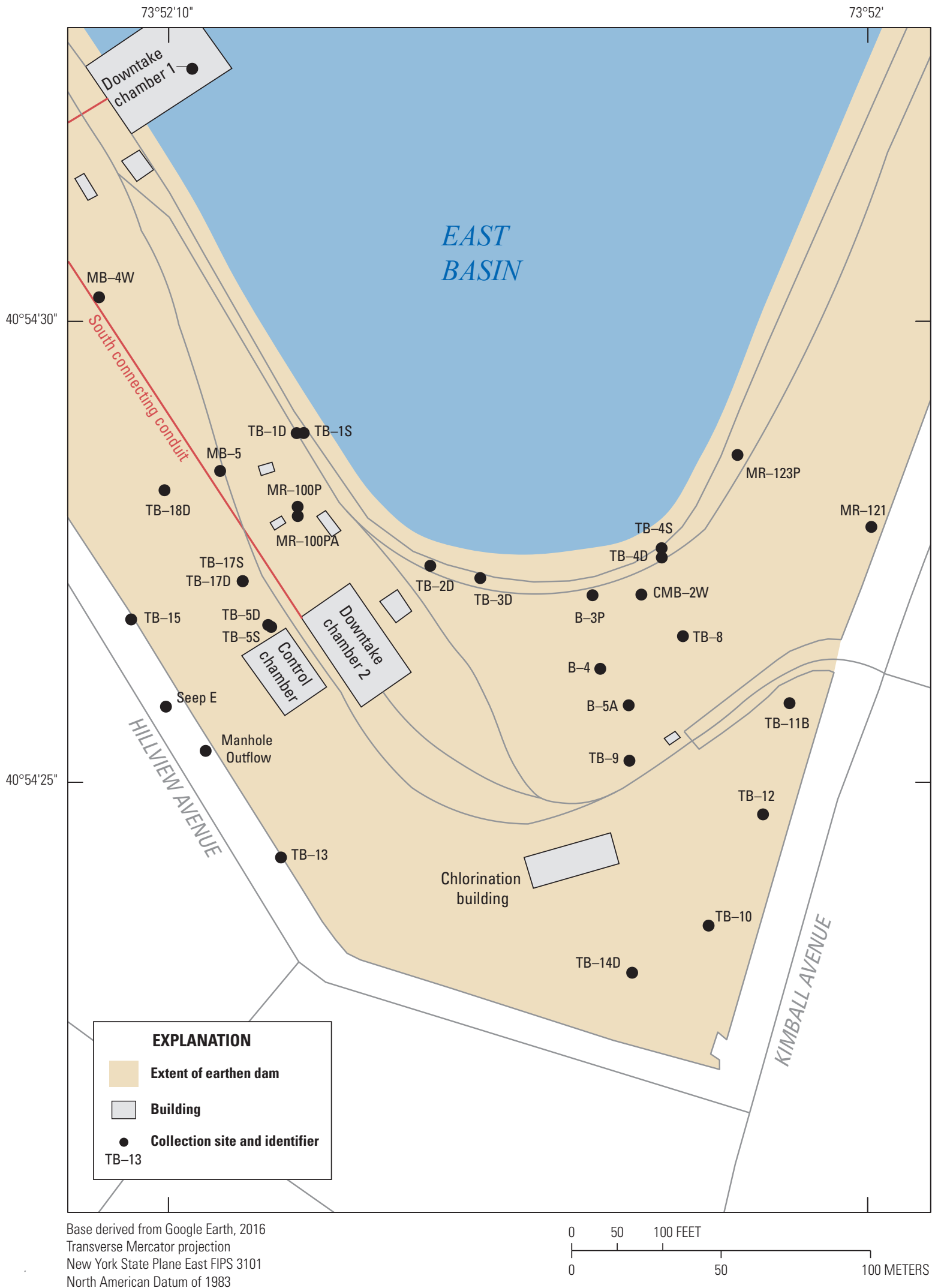

Figure 2. Sites that were sampled for water quality on the southern embankment at the Hillview Reservoir, Westchester County, New York, 2015. 
Table 1. Site information for $A$, groundwater wells and $B$, East Basin, seep $A$, seep $E$, and manhole outflow at the Hillview Reservoir, Westchester County, New York, 2006 and 2015.

[Location of sites sampled in 2015 shown in figure 1; sites not sampled in 2015 are not shown on figures in this report. Latitude and longitude are referenced to the North American Datum of 1983. All altitudes are in feet above National Geodetic Vertical Datum of 1929. All depths are in feet below land surface.

NYSDEC, New York State Department of Environmental Conservation; ID, identifier; USGS, United States Geological Survey; —, no data; NA, not available]

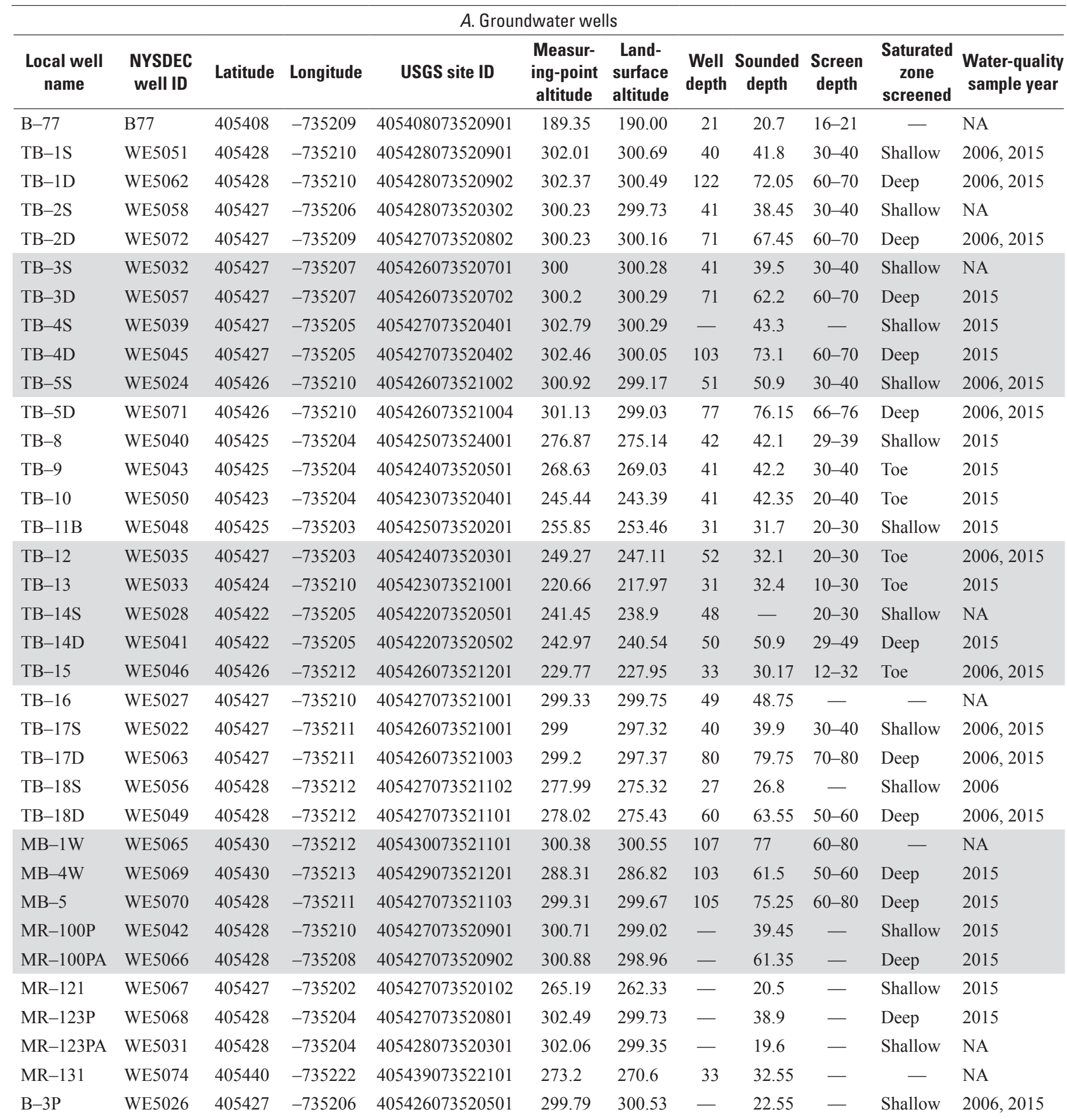


Table 1. Site information for $A$, groundwater wells and $B$, East Basin, seep $A$, seep $E$, and manhole outflow at the Hillview Reservoir, Westchester County, New York, 2006 and 2015.-Continued

[Location of sites sampled in 2015 shown in figure 1; sites not sampled in 2015 are not shown on figures in this report. Latitude and longitude are referenced to the North American Datum of 1983. All altitudes are in feet above National Geodetic Vertical Datum of 1929. All depths are in feet below land surface.

NYSDEC, New York State Department of Environmental Conservation; ID, identifier; USGS, United States Geological Survey; —, no data; NA, not available]

\begin{tabular}{|c|c|c|c|c|c|c|c|c|c|c|c|c|c|}
\hline \multirow[b]{2}{*}{$\begin{array}{l}\text { Local well } \\
\text { name }\end{array}$} & \multicolumn{13}{|c|}{ A. Groundwater wells-Continued } \\
\hline & \multicolumn{2}{|c|}{$\begin{array}{l}\text { NYSDEC } \\
\text { well ID }\end{array}$} & Latitude & Longitude & \multicolumn{2}{|c|}{ USGS site ID } & $\begin{array}{l}\text { Measur- } \\
\text { ing-point } \\
\text { altitude }\end{array}$ & \multirow{2}{*}{\begin{tabular}{|c|}
$\begin{array}{c}\text { Land- } \\
\text { surface } \\
\text { altitude }\end{array}$ \\
282.15 \\
\end{tabular}} & \multirow{2}{*}{$\begin{array}{r}\begin{array}{r}\text { Well } \\
\text { depth }\end{array} \\
-\end{array}$} & \multirow{2}{*}{$\begin{array}{c}\begin{array}{c}\text { Sounded } \\
\text { depth }\end{array} \\
35.67\end{array}$} & \multirow{2}{*}{$\begin{array}{c}\begin{array}{c}\text { Screen } \\
\text { depth }\end{array} \\
-\end{array}$} & $\begin{array}{l}\text { Saturated } \\
\text { zone } \\
\text { screened }\end{array}$ & $\begin{array}{l}\text { Water-quality } \\
\text { sample year }\end{array}$ \\
\hline B-4 & WE5 & & 405426 & -735206 & 405425073520 & 502 & 283.81 & & & & & Shallow & 2015 \\
\hline $\mathrm{B}-5 \mathrm{~A}$ & WE5 & & 405425 & -735206 & 405425073520 & 501 & 279.45 & 277.35 & - & 35.45 & - & Shallow & 2015 \\
\hline HESF-8S & WE5 & & 405443 & -735228 & 405442073522 & 801 & 243.88 & 241.78 & 10 & 10.7 & $5-10$ & Shallow & NA \\
\hline HESF-8D & WE5 & & 405443 & -735228 & 405442073522 & 701 & 244.15 & 241.81 & 19 & 19.3 & $14-19$ & Deep & NA \\
\hline CMB-2W & WE5 & & 405427 & -735205 & 405426073520 & 502 & 301.03 & 299 & - & 35.4 & - & Shallow & 2015 \\
\hline 104-P & WE5 & & 405436 & -735217 & 405436073521 & 702 & 301.72 & 300 & - & 41.3 & - & - & NA \\
\hline 104-PA & WE5 & & 405436 & -735217 & 405436073521 & 701 & 302.98 & 300 & - & 20.7 & - & - & NA \\
\hline $105-\mathrm{P}$ & WE5 & & 405441 & -735220 & 405440073522 & 001 & 302.65 & 300.7 & - & 42.65 & - & - & 2015 \\
\hline 106-P & WE5 & & 405444 & -735224 & 405444073522 & 301 & 301.2 & 298.9 & - & 42.4 & - & - & NA \\
\hline 106-PA & WE5 & & 405444 & -735224 & 405444073522 & 401 & 301.33 & 296.6 & - & 42.62 & - & - & NA \\
\hline 109-P & WE5 & & 405454 & -735223 & 405454073522 & 201 & 303.1 & 300.1 & - & 34.75 & - & - & NA \\
\hline 110-P & WE5 & & 405458 & -735220 & 405458073521 & 901 & 303.4 & 302.1 & - & 32.65 & - & - & NA \\
\hline 111 & - & & 405502 & -735215 & - & & - & - & - & - & - & - & NA \\
\hline $\mathrm{X}$ & WE5 & & 405459 & -735209 & 405458073520 & 901 & 302.1 & 299.9 & - & 38.35 & - & - & NA \\
\hline Y-PA & WE5 & & 405454 & -735207 & 405454073520 & 701 & 302.63 & 300 & - & 21.14 & - & - & NA \\
\hline Y-PD & WE5 & & 405454 & -735207 & 405454073520 & 702 & 302.45 & 300 & - & 42.4 & - & - & NA \\
\hline Z-PA & WE5 & & 405445 & -735203 & 405445073520 & 201 & 302.75 & 300.4 & - & 19.86 & - & - & NA \\
\hline Z-PD & WE5 & & 405445 & -735203 & 405445073520 & 202 & 302.06 & 299.4 & - & 46.12 & - & - & NA \\
\hline PA & WE5 & & 405432 & -735159 & 405432073515 & 801 & 303.17 & 300.3 & - & 22.05 & - & - & NA \\
\hline PD & WE5 & & 405437 & -735159 & 405436073515 & 801 & 302.76 & 300.2 & - & 42.3 & - & - & NA \\
\hline DT-2 & WE5 & & 405503 & -735212 & 405502073521 & 101 & 300.9 & 298.92 & - & 44.8 & - & - & 2015 \\
\hline WE-5078 & WE5 & & 405441 & -735157 & 405441073515 & 701 & 290.6 & 287.6 & 124 & 124.2 & - & - & 2015 \\
\hline WE-5079 & WE5 & & 405449 & -735201 & 405449073520 & 001 & 277.58 & 274.6 & 91 & 91.15 & - & - & 2015 \\
\hline \multicolumn{14}{|c|}{$B$. East Basin, seep $A$, seep $E$, and manhole outflow } \\
\hline \multicolumn{3}{|c|}{ Local site name } & \multicolumn{3}{|c|}{ Station name } & \multicolumn{2}{|c|}{ Longitude } & atitude & \multicolumn{2}{|c|}{ USGS site ID } & \multicolumn{2}{|c|}{$\begin{array}{l}\text { Land surface } \\
\text { alititude }\end{array}$} & $\begin{array}{l}\text { Water-quality } \\
\text { sample year }\end{array}$ \\
\hline \multicolumn{3}{|l|}{ East Basin } & \multicolumn{3}{|c|}{ Downtake Chamber 1} & \multicolumn{2}{|c|}{-735210} & 405433 & \multicolumn{2}{|c|}{405432073521001} & \multicolumn{2}{|c|}{-} & 2006,2015 \\
\hline \multicolumn{2}{|l|}{ Seep A } & \multicolumn{4}{|c|}{$\begin{array}{l}\text { Hillview Reservoir hillside seep A near } \\
\text { Yonkers, New York }\end{array}$} & \multicolumn{2}{|c|}{-735210} & 405427 & \multicolumn{2}{|c|}{405426073521101} & \multicolumn{2}{|c|}{255.3} & 2006 \\
\hline Seep E & & & $\begin{array}{l}\text { lview Rese } \\
\text { Yonkers, Ne }\end{array}$ & $\begin{array}{l}\text { ervoir hillsid } \\
\text { ew York }\end{array}$ & e seep E near & -73 & 5210 & 405426 & 4054250 & 073521101 & & 21.6 & 2006,2015 \\
\hline Manhole out & low & & Inhole outfl & low near sto & ne wall & -73 & 5211 & 405425 & 4054250 & 073521102 & & - & 2015 \\
\hline
\end{tabular}




\section{Previous Investigations}

In 2001, the New York City Department of Environmental Protection (NYCDEP) drilled 25 wells at the southern end of the reservoir adding to the 32 wells previously installed around the reservoir. The NYCDEP drilled the wells in an effort to locate the potential sources of the continuous flowing seep that was first observed in 1999 (George Schmitt, New York City Department of Environmental Protection, written commun., 2007). The NYCDEP approach included taking periodic depth-to-water measurements and sampling reservoir and spring water for major ions (Malcolm Pirnie, Inc. and TAMS Consultants, Inc., 2002; Chu and others, 2013). Beginning in 2005, the U.S. Geological Survey used a multi-disciplinary approach to investigate the relevant hydrogeologic framework and characterize the local groundwater-flow system to determine possible sources of the seeps (Chu and others, 2013). In 2006, water quality samples were collected from 12 groundwater observation wells, the East Basin at downtake chamber 1, and seeps A and E (fig. 2) to provide a basic understanding of the hydrologic interconnections of the wells and the seeps to the basin. In 2014, the original study was extended to further investigate the hydrology of the embankment relative to the seeps. During this final phase of the project, the water-quality data that are presented in this report were collected and analyzed.

\section{Methods of Water-Quality Sample Collection}

During fall 2015, the USGS sampled 37 sites (every site available) using open-top teflon bailers or a submersible pump. Thirty-four of the 37 sites that were sampled are groundwater wells within the Hillview Reservoir. The other three sites were at the East Basin at downtake chamber 1, seep E along the stone retaining wall near Hillview Avenue, and the discharge site from an outflow pipe within a storm manhole along Hillview Avenue (fig. 2). Thirteen sites that were originally sampled during 2006 were sampled again in 2015 for a temporal comparison of water-quality conditions within the earthen embankment. The 13 sites that were sampled in 2006 and 2015 are TB-1S, TB-1D, TB-2D, TB-5S, TB-5D, TB-12, TB-15, TB-17S, TB-17D, TB-18D, B-3P, seep E, and the East Basin at downtake chamber 1 (fig. 2).Water-quality samples were collected in accordance with the USGS National Field Manual for the Collection of Water-Quality Data (USGS, variously dated). Because many of the wells are screened in low permeability deposits where water levels are slow to recover after pumping, teflon bailers were used (USGS, variously dated) instead of a pump to evacuate (purge) the standard three-casing volumes (USGS, 2006). A submersible pump was used to purge monitoring wells TB-1D, TB-2D, TB-5D, TB-8, and TB-9, whereas the remaining 29 wells were purged using an open-top bailer. The standard three-casing volumes were not purged from monitoring wells TB-3D and B-5A because water-level recovery from drawdown to approximately 90 percent of the original volume in the well could not be achieved within a reasonable timeframe (USGS, variously dated). After collection, the water-quality samples were chilled and shipped overnight to the USGS National Water Quality Laboratory (NWQL) in Denver, Colorado, where they were analyzed for nutrients (USGS, 2017b), major ions (USGS, 2017c), metals (USGS, 2017c), pesticides and their degradates (USGS, 2017d), and volatile organic compounds (USGS, 2017e).

Replicate samples were collected from an open-top bailer at monitoring well TB-15, and from a dedicated East Basin sampling tap inside downtake chamber 1 (fig. 2; table 2, in back of report). The replicate samples were collected approximately a half-hour after the primary (regular) samples were collected to identify variability of the sampling and analysis system (USGS, variously dated). A disparity of iron concentration was detected between the primary and replicate samples collected at TB-15.

An equipment blank was performed in the field by passing quality-assured (NWQL approved) blank water through an open-top bailer for inorganic and organic analyses (USGS, 1992, variously dated). Filtered and unfiltered samples were collected, preserved, and shipped according to the procedures of quality control for equipment cleaning outlined in the USGS National Field Manual for the Collection of WaterQuality Data (USGS, variously dated). Barium, iron, and manganese were detected in the unfiltered blank samples but concentrations were well below the concentrations detected in the water-quality samples. Temperature, $\mathrm{pH}$, turbidity, and specific conductance were recorded in the field for each water sample at the time of collection and are listed in table 2 (in back of report).

\section{Data Dissemination}

The tabulated results of the water-quality analysis and the field parameters that were collected during sampling of the 37 sites in the 2015 study are shown in table 2. A digital version of these data can also be downloaded from the USGS National Water Information System website (USGS, 2016). 


\section{References Cited}

Asselstine, E.S., and Grossman, I.G., 1955, The groundwater resources of Westchester County, New York, part 1 of records of wells and test holes: New York State Water Power and Control Commission Bulletin GW-35, 79 p., 3 pls.

Baskerville, C.A., 1982, Adoption of the name Hutchinson River Group and its subdivisions in Bronx and Westchester Counties, southeastern New York, in Stratigraphic notes, 1980-1982: U.S. Geological Survey Bulletin 1529-H, p. H1-H10. [Also available at https://pubs.er.usgs.gov/ publication/b1529H.]

Baskerville, C.A., 1992, Bedrock and engineering geologic maps of Bronx County and parts of New York and Queens Counties, New York: U.S. Geological Survey Miscellaneous Investigations Series, map I-2003, 2 sheets, scale 1:24,000. [Also available at https://pubs.er.usgs.gov/publication/ i2003.]

Chu, Anthony; Stumm, Frederick; Joesten, P.K.; and Noll, M.L., 2013, Geophysical and hydrologic analysis of an earthen dam site in southern Westchester County, New York: U.S. Geological Survey Scientific Investigations Report 2012-5247, 64 p. [Also available at http:// pubs.usgs.gov/sir/2012/5247/.]

Malcolm Pirnie, Inc., and TAMS Consultants, Inc., 2002, Capital project W-10, Hillview Reservoir-cover, phase I, dividing wall stability buttress construction; south embankment monitoring and leakage investigations: U.S. Environmental Protection Agency, 18 p.

U.S. Geological Survey [USGS], 1992, Technology transfer-Availability of equipment blank water for inorganic and organic analysis: U.S. Geological Survey National Water Quality Laboratory Technical Memorandum 1992.01, accessed March 10, 2017, at https://nwql.usgs.gov/tech_ memos/nwql.1992-01.pdf.

U.S. Geological Survey [USGS], 2006, Collection of water samples (ver. 2.0): U.S. Geological Survey Techniques of Water-Resources Investigations, book 9, chap. A4, accessed March 9, 2017, at https://water.usgs.gov/owq/FieldManual/.
U.S. Geological Survey [USGS], 2011, Parameters: U.S. Geological Survey National Water Information System help system website, accessed July 25, 2017, at https:// help.waterdata.usgs.gov/codes-and-parameters/parameters.

U.S. Geological Survey [USGS], 2016, Water-quality samples for the Nation, in USGS water data for the nation: U.S. Geological Survey National Water Information System database, accessed March 23, 2017, at https:// doi.org/10.5066/F7P55KJN.

U.S. Geological Survey [USGS], 2017a, LCMS/MS pesticides in filtered water: U.S. Geological Survey National Water Quality Lab Catalog Schedule 2437 web page, accessed March 10, 2017, at http://wwwnwql.cr.usgs.gov/USGS/ catalog/index.cfm? $a=b s \& s a=s f \& s a p=2437$.

U.S. Geological Survey [USGS], 2017b, Nutrients: U.S. Geological Survey National Water Quality Lab Catalog Schedule 101 web page, accessed March 8, 2017, at http://wwwnwql.cr.usgs.gov/USGS/catalog/ index.cfm? $a=b s \& s a=s f \& s a p=101$.

U.S. Geological Survey [USGS], 2017c, Metals: U.S. Geological Survey National Water Quality Lab Catalog Schedule 1294 web page, accessed March 10, 2017, at http://wwwnwql.cr.usgs.gov/USGS/catalog/ index.cfm?a $=$ bs\&sa=sf\&sap=1294.

U.S. Geological Survey [USGS], 2017d, Pesticides and their degradates: U.S. Geological Survey National Water Quality Lab Catalog Schedule 2437 web page, accessed March 10, 2017, at https://wwwnwql.cr.usgs.gov/USGS/catalog/ index.cfm? $\mathrm{a}=\mathrm{bs} \& \mathrm{sa}=\mathrm{s} \& \mathrm{sap}=2437$.

U.S. Geological Survey [USGS], 2017e, Volatile organic compounds: U.S. Geological Survey National Water Quality Lab Catalog Schedule 2020 web page, accessed March 10, 2017, at http://wwwnwql.cr.usgs.gov/USGS/catalog/ index.cfm? $a=b s \& s a=s f \& s a p=2020$.

U.S. Geological Survey [USGS], [variously dated], National field manual for the collection of water-quality data: U.S. Geological Survey Techniques of Water-Resources Investigations, book 9, chaps. A1-A10, [variously paged]. [Also available at https://water.usgs.gov/owq/FieldManual/.] 

Table 2 


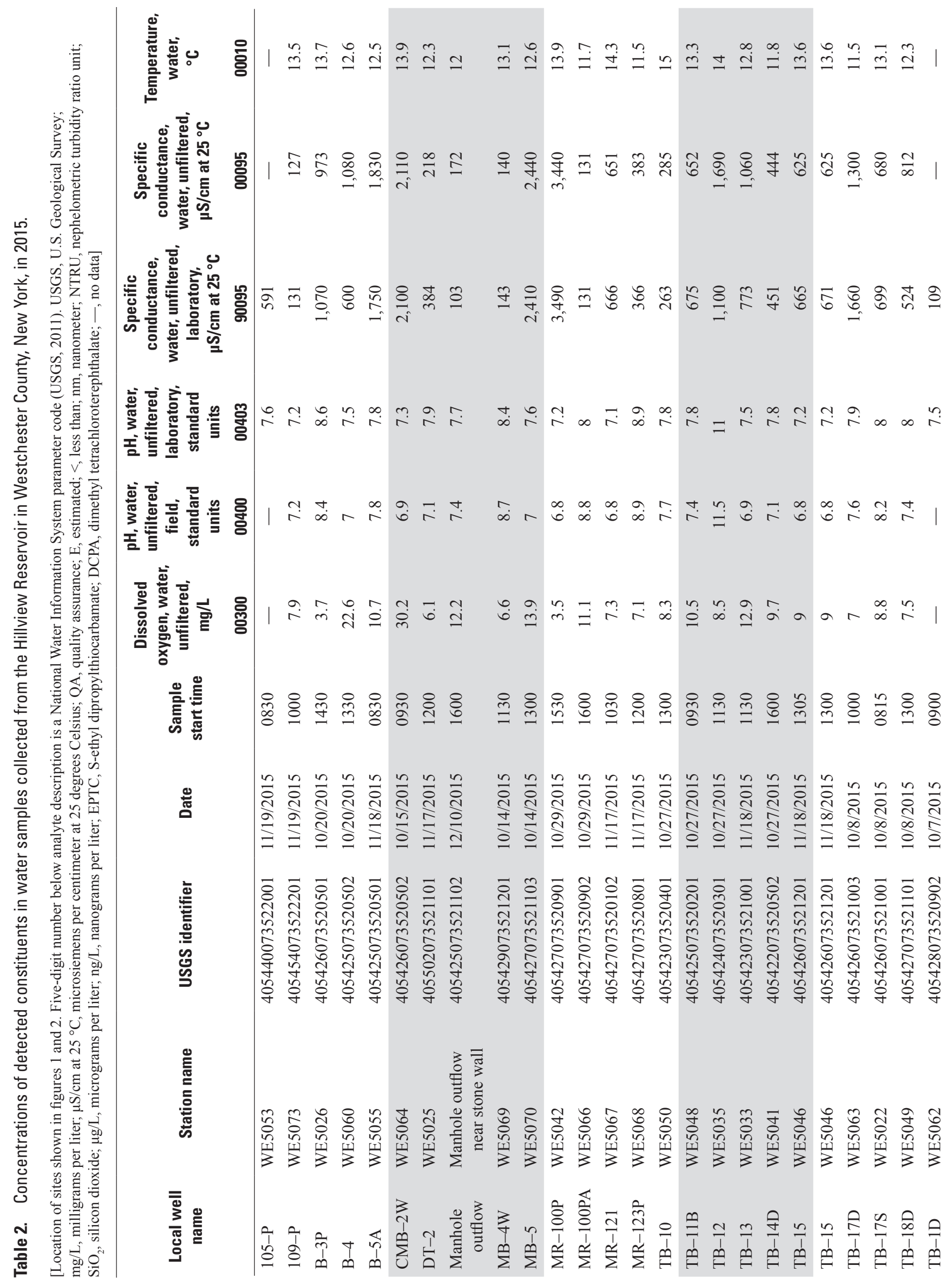




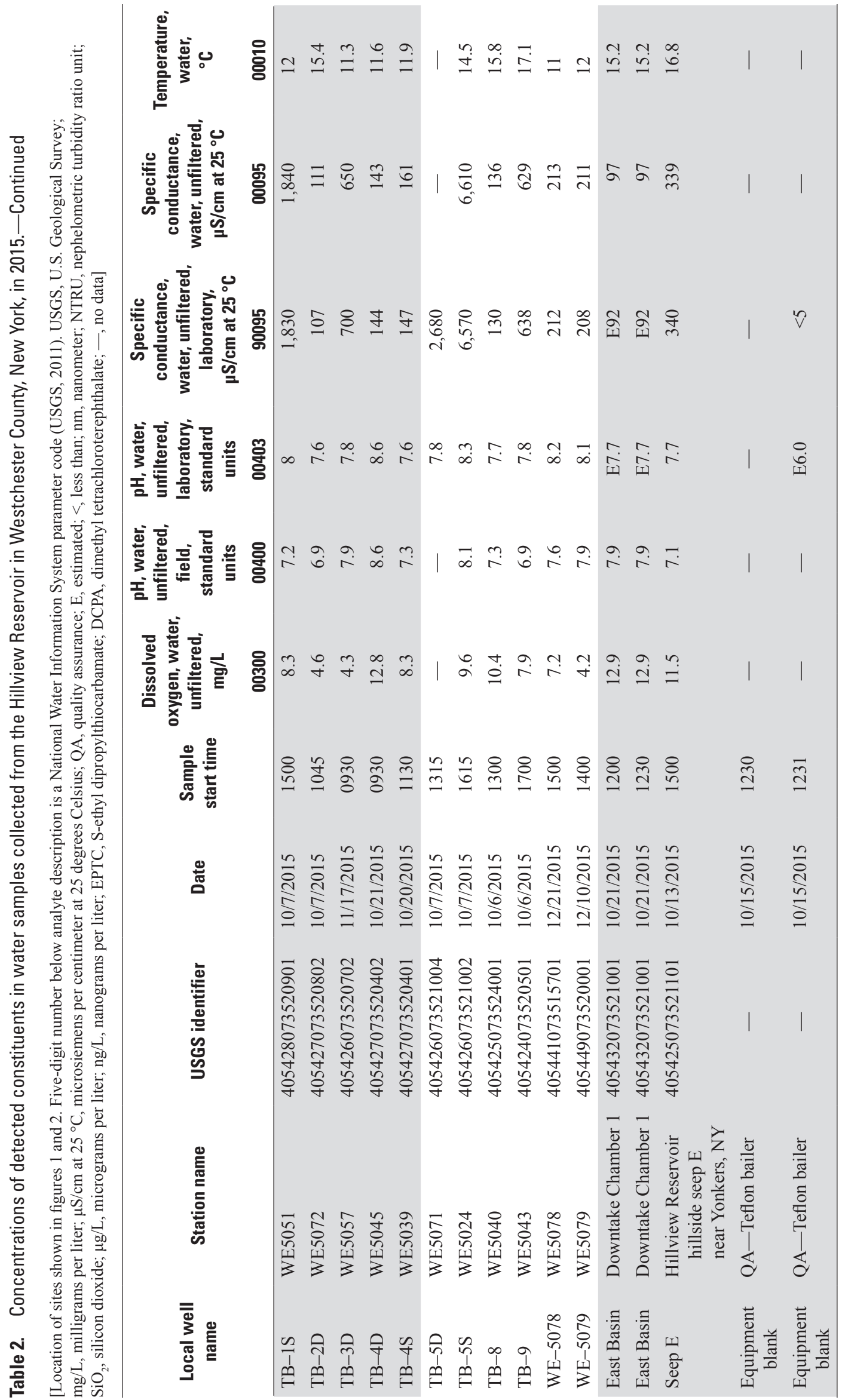




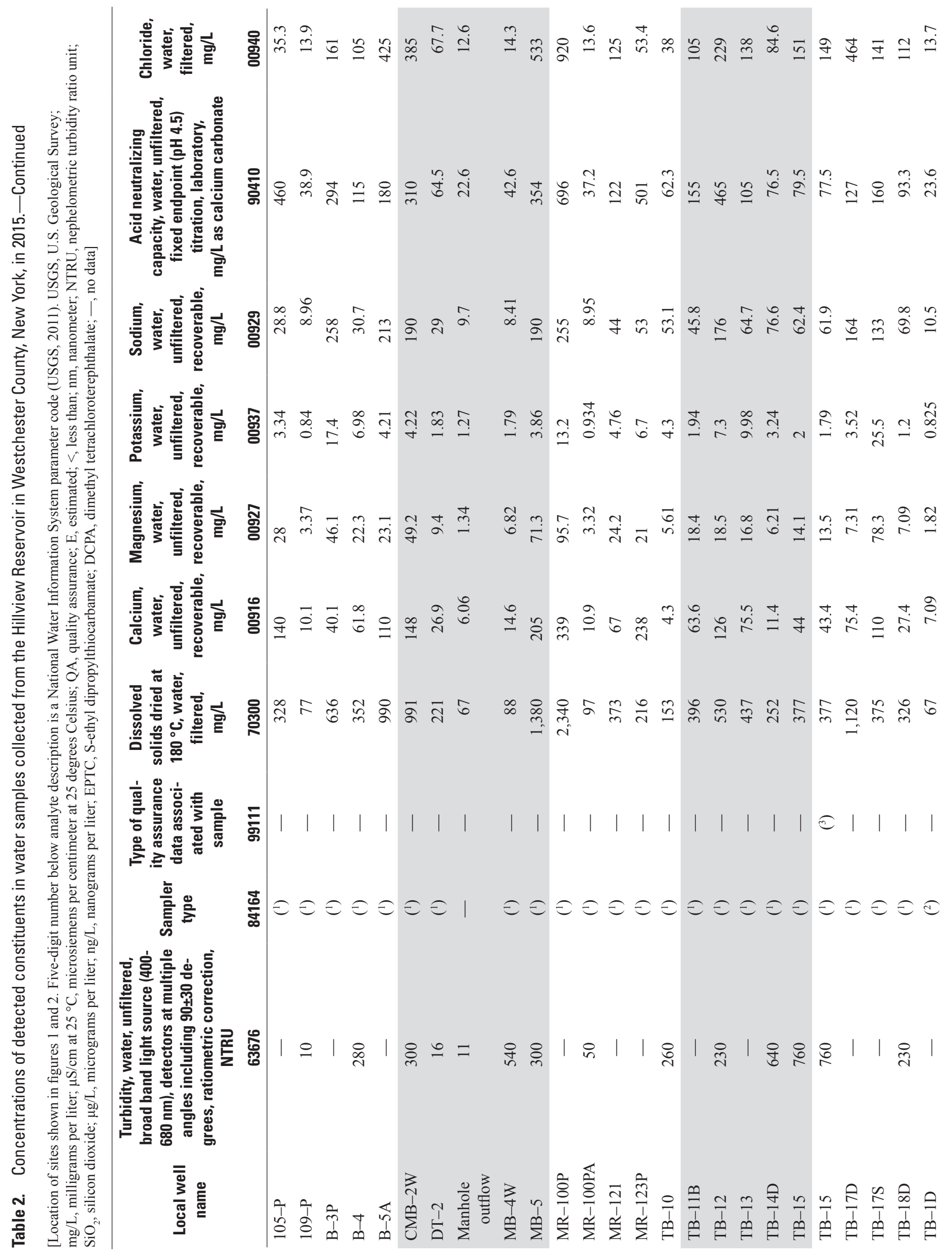




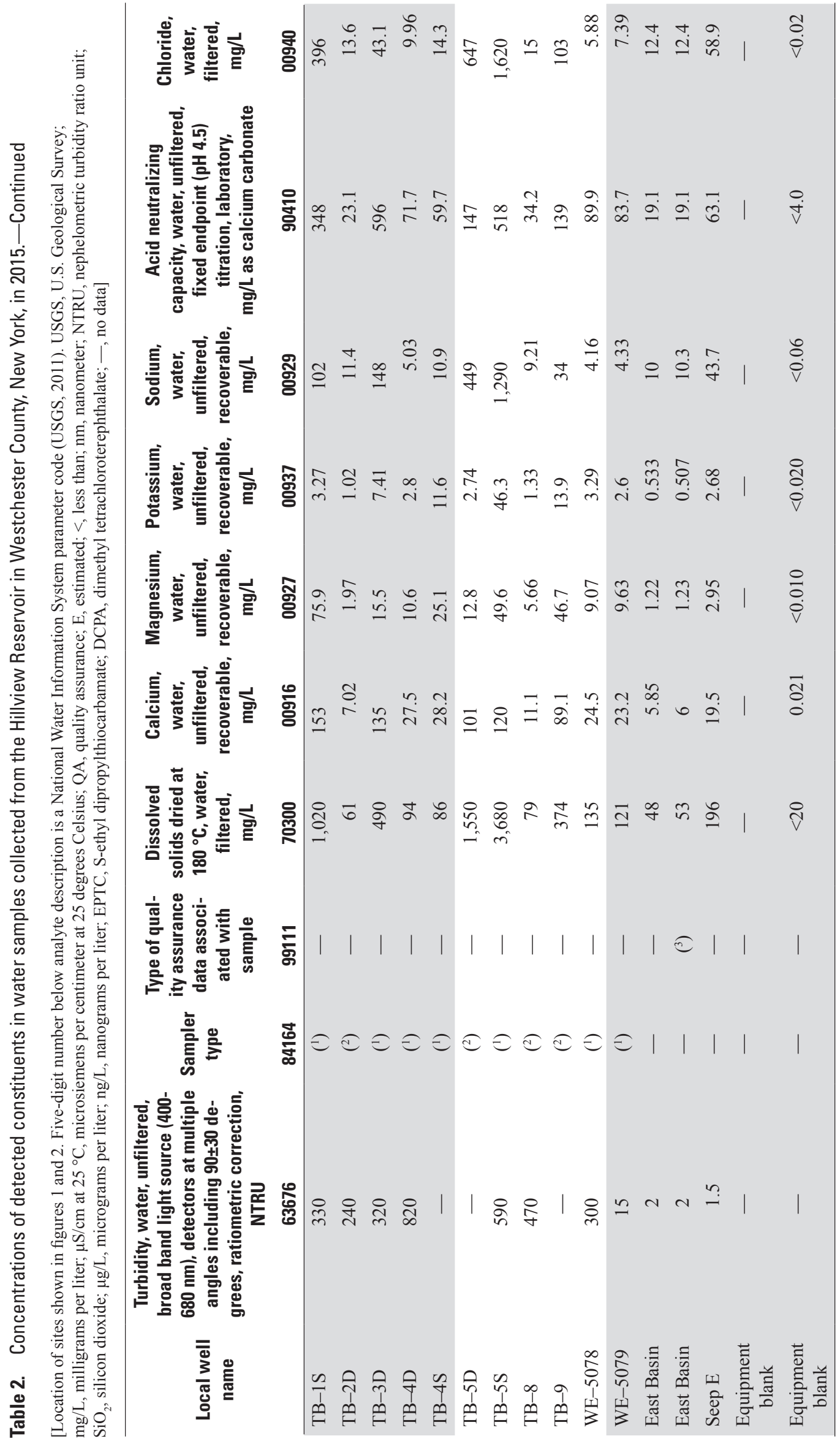




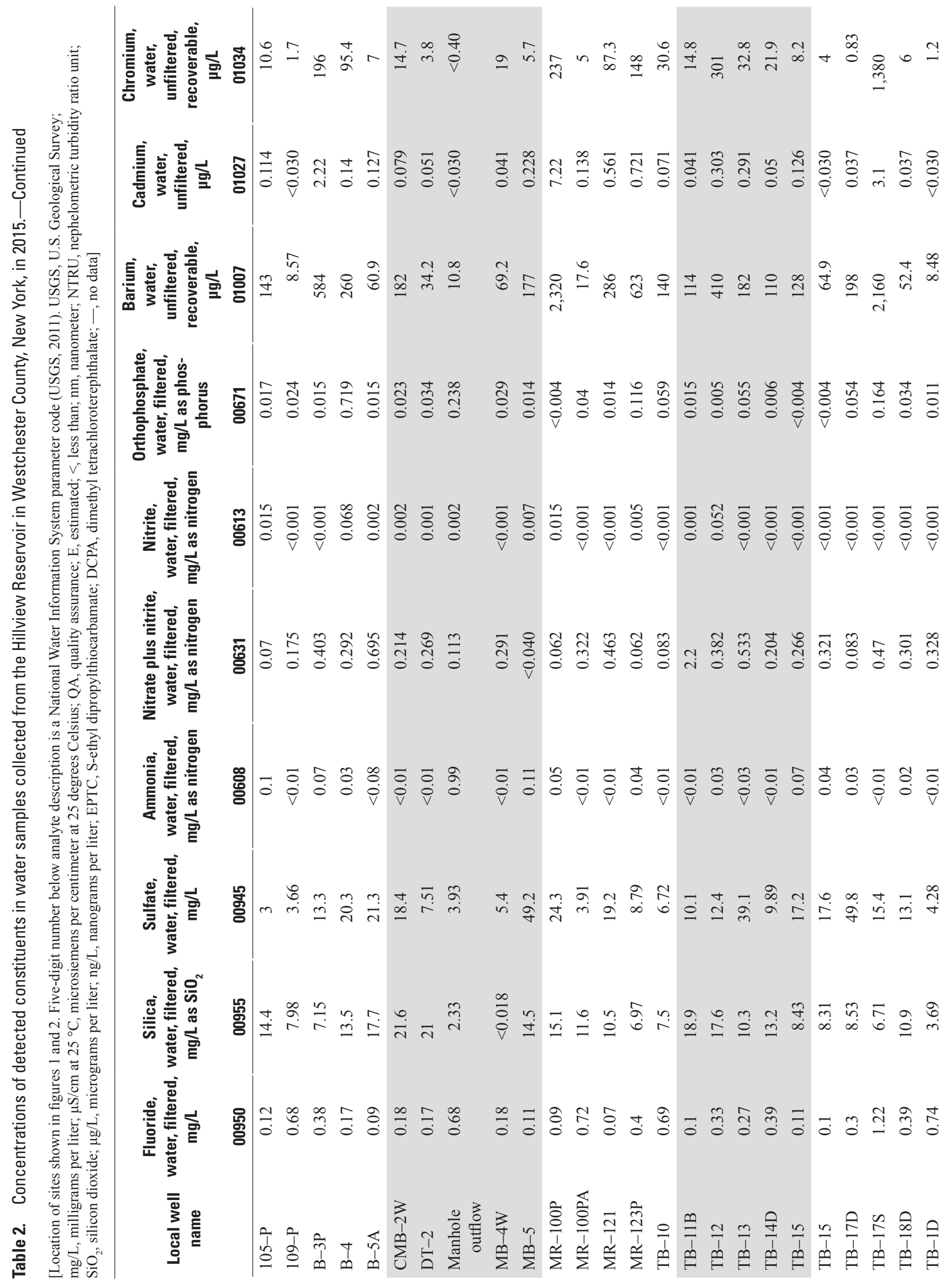




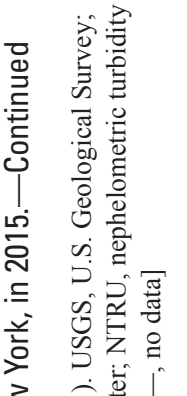

|

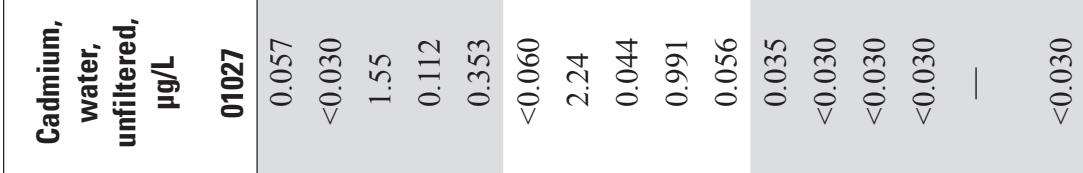

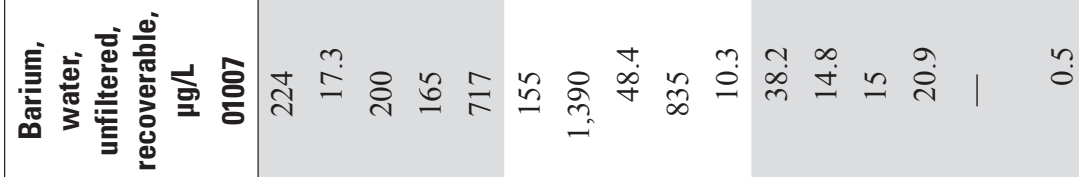

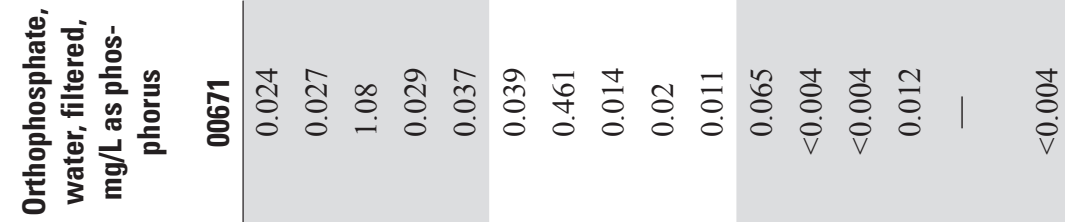

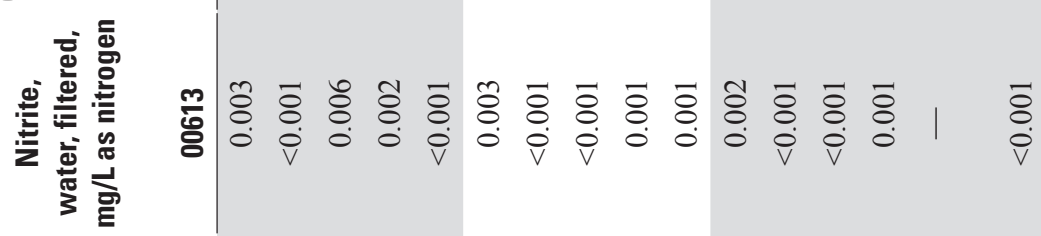

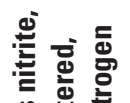

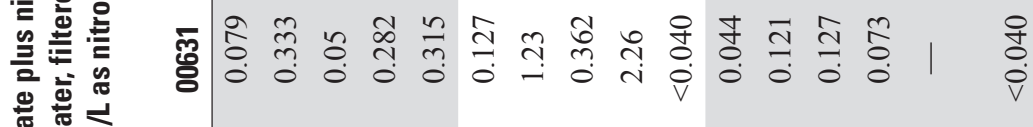

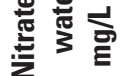

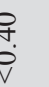

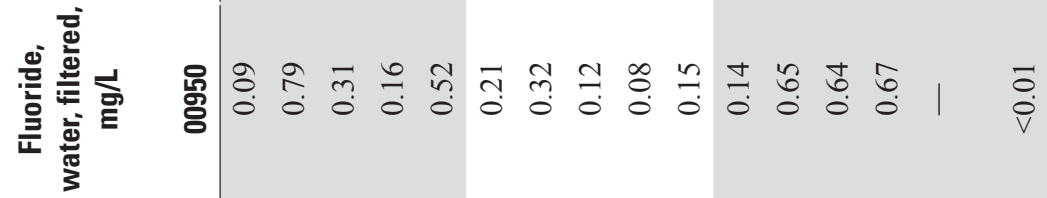

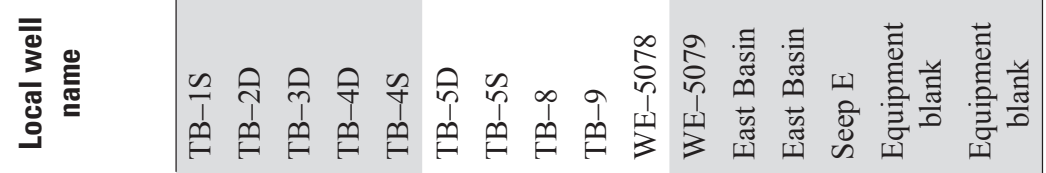




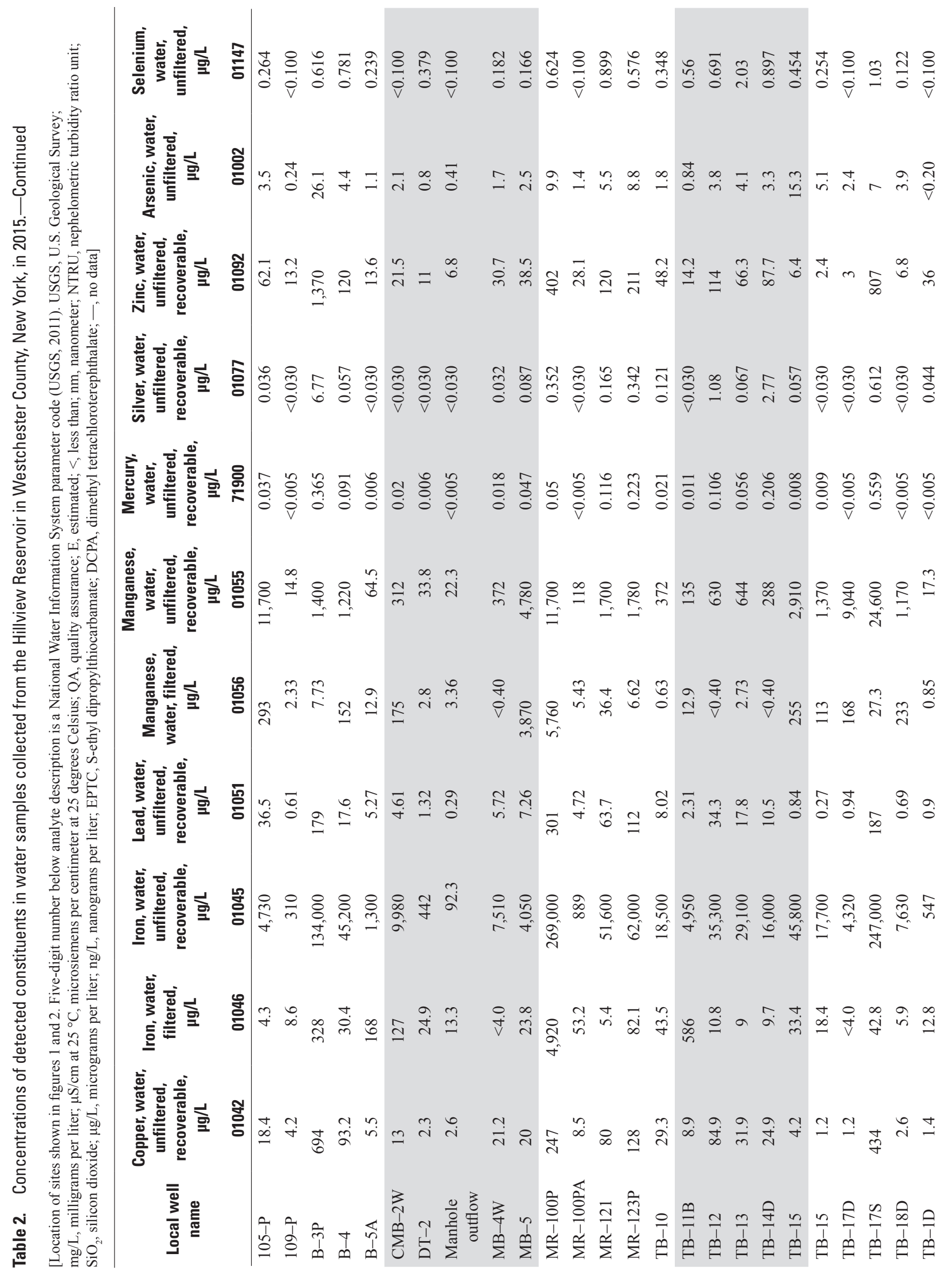




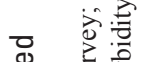

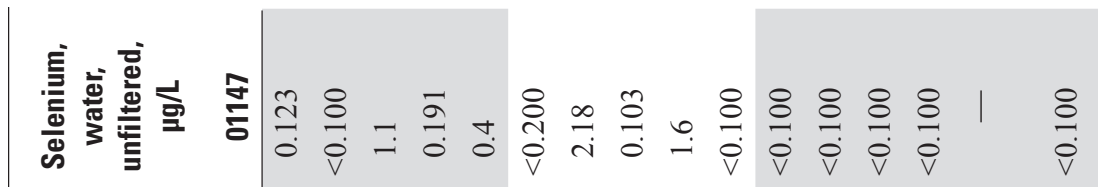

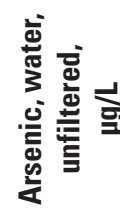

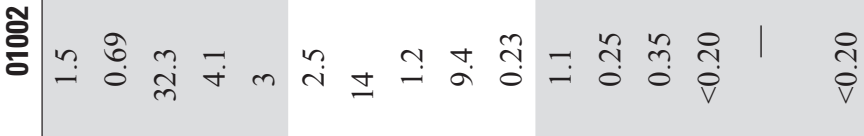

离宽

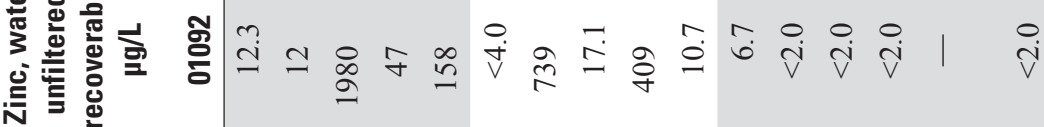

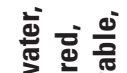

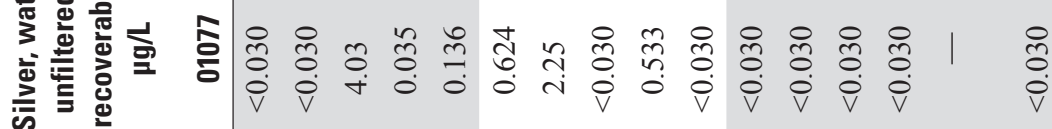

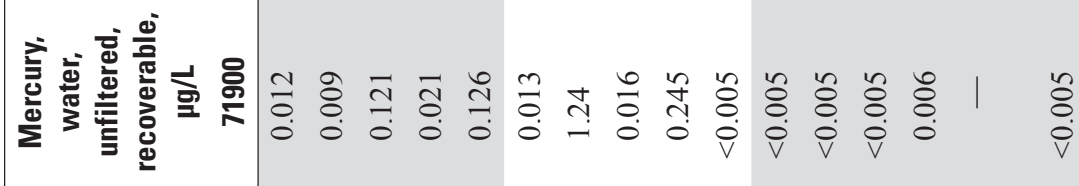

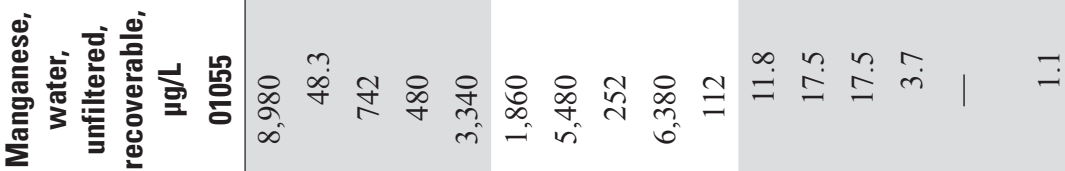

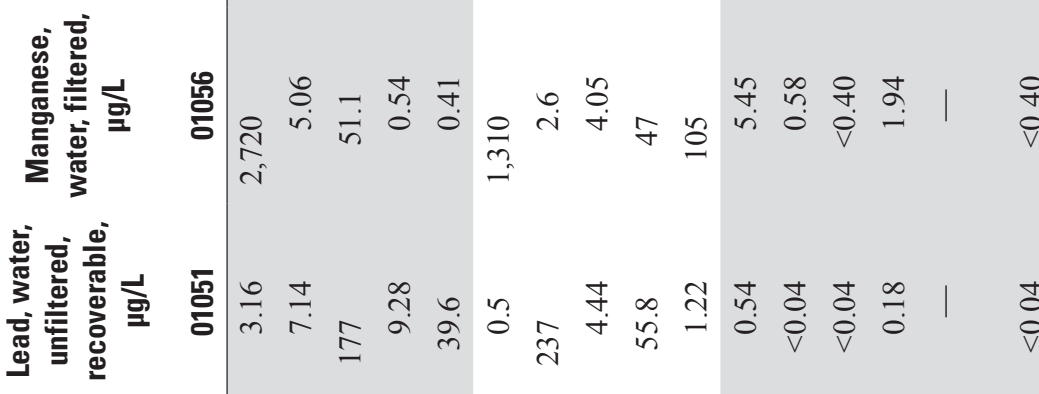

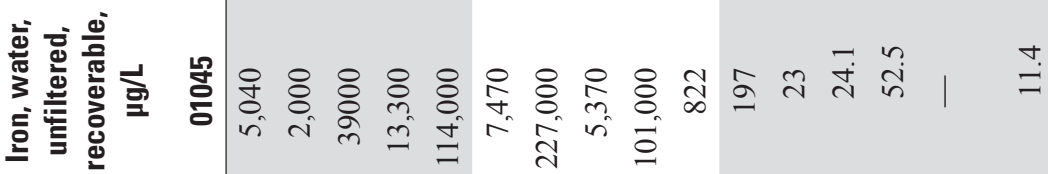

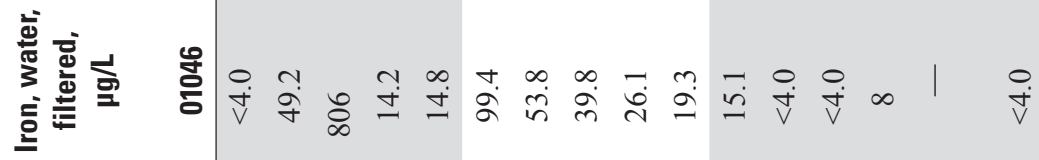

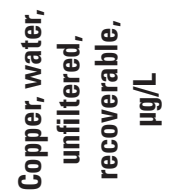

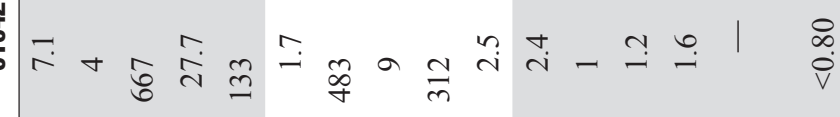

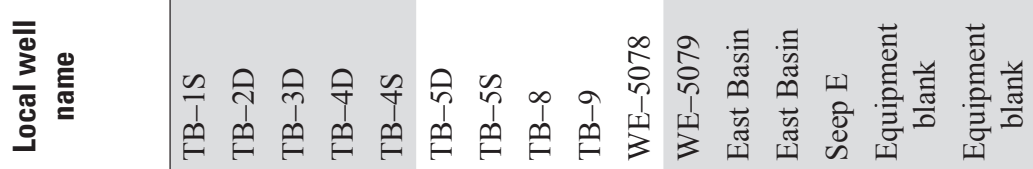




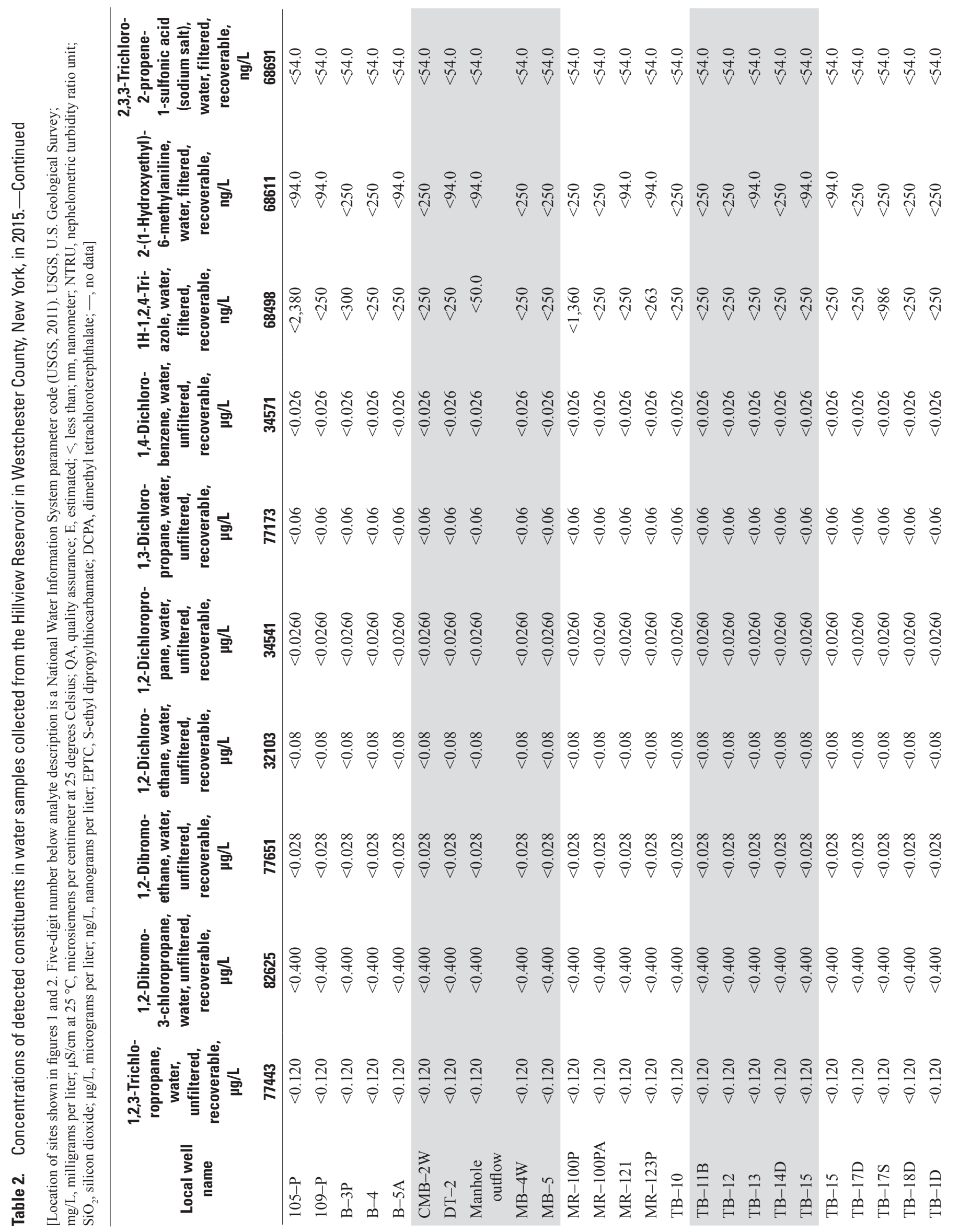




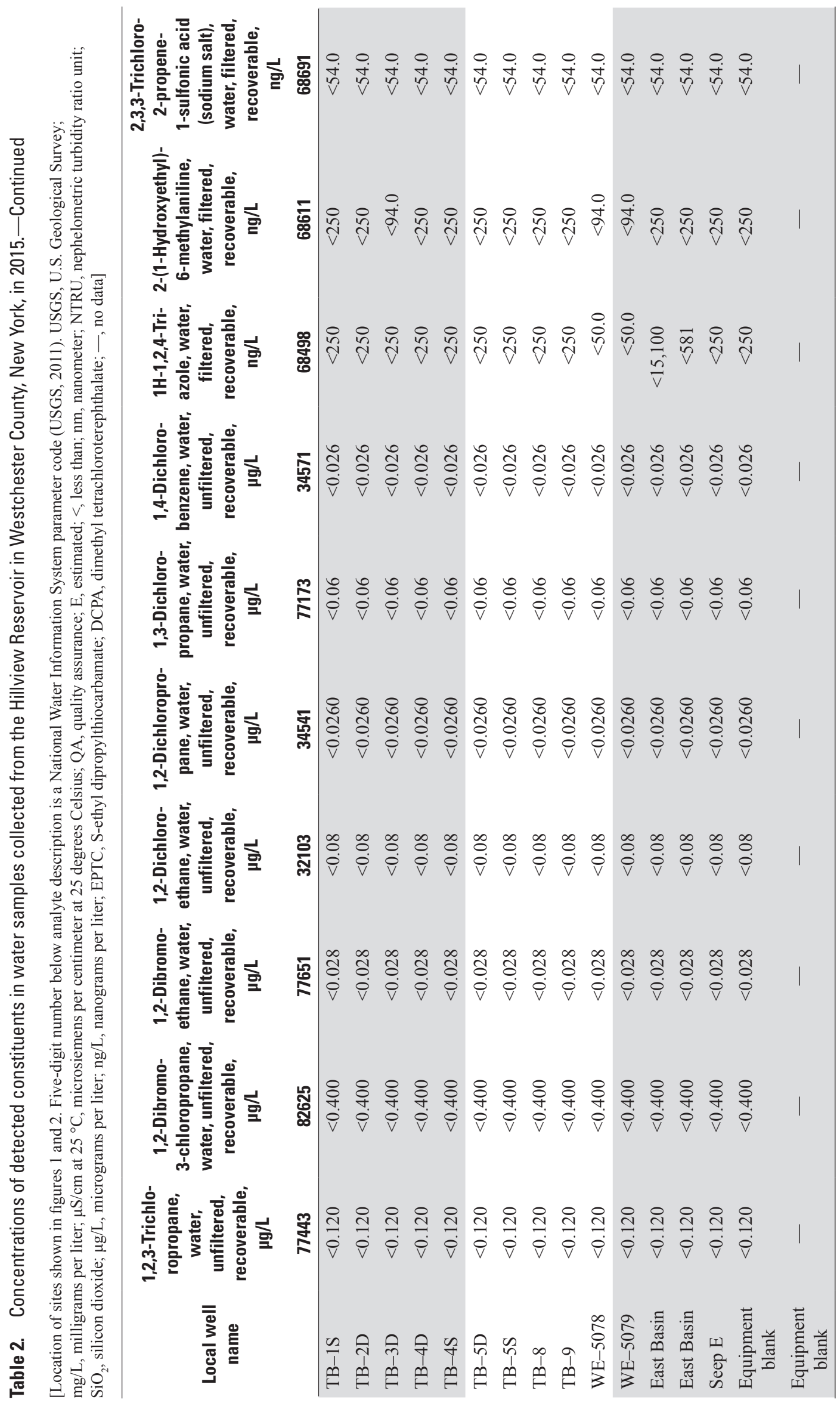




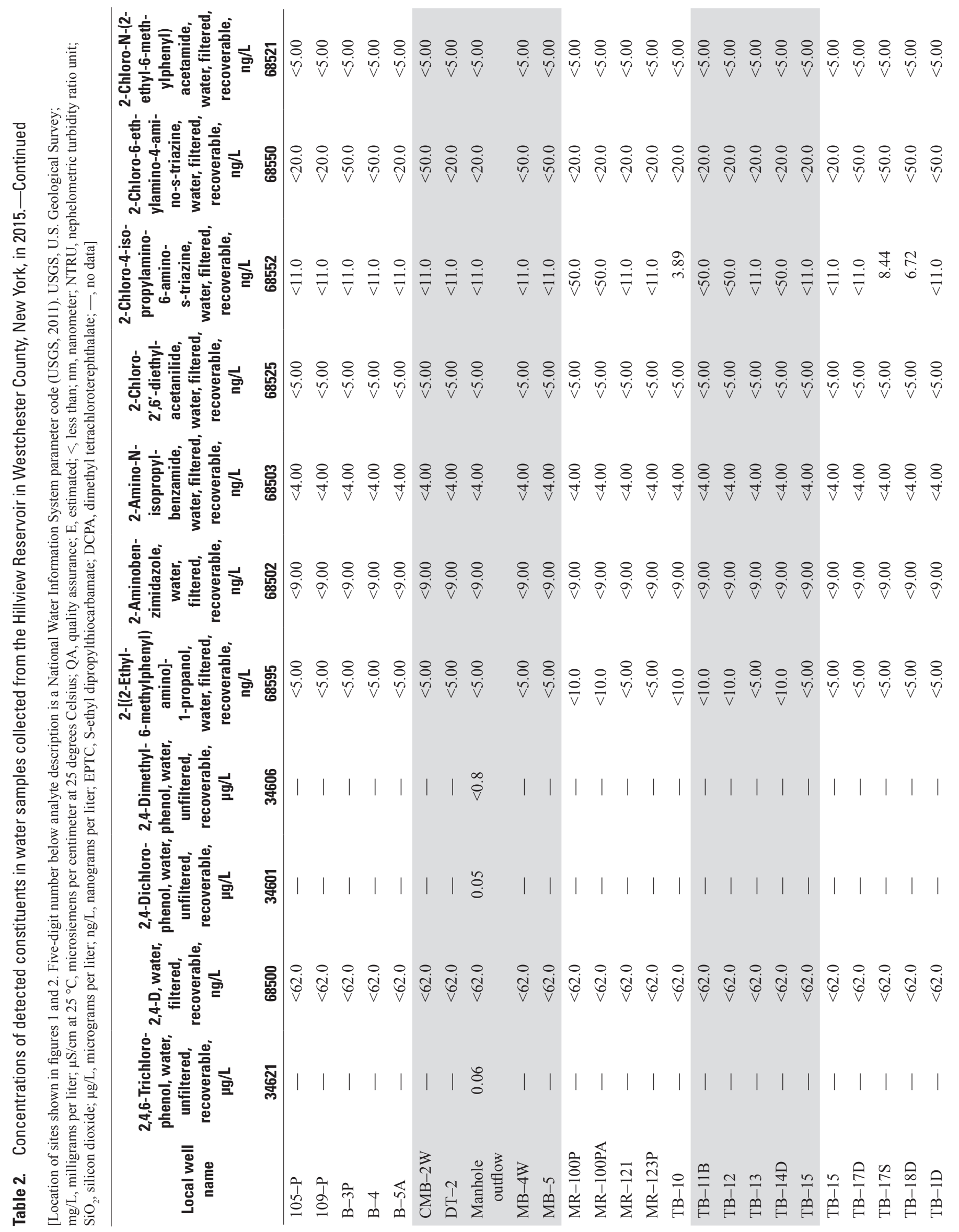




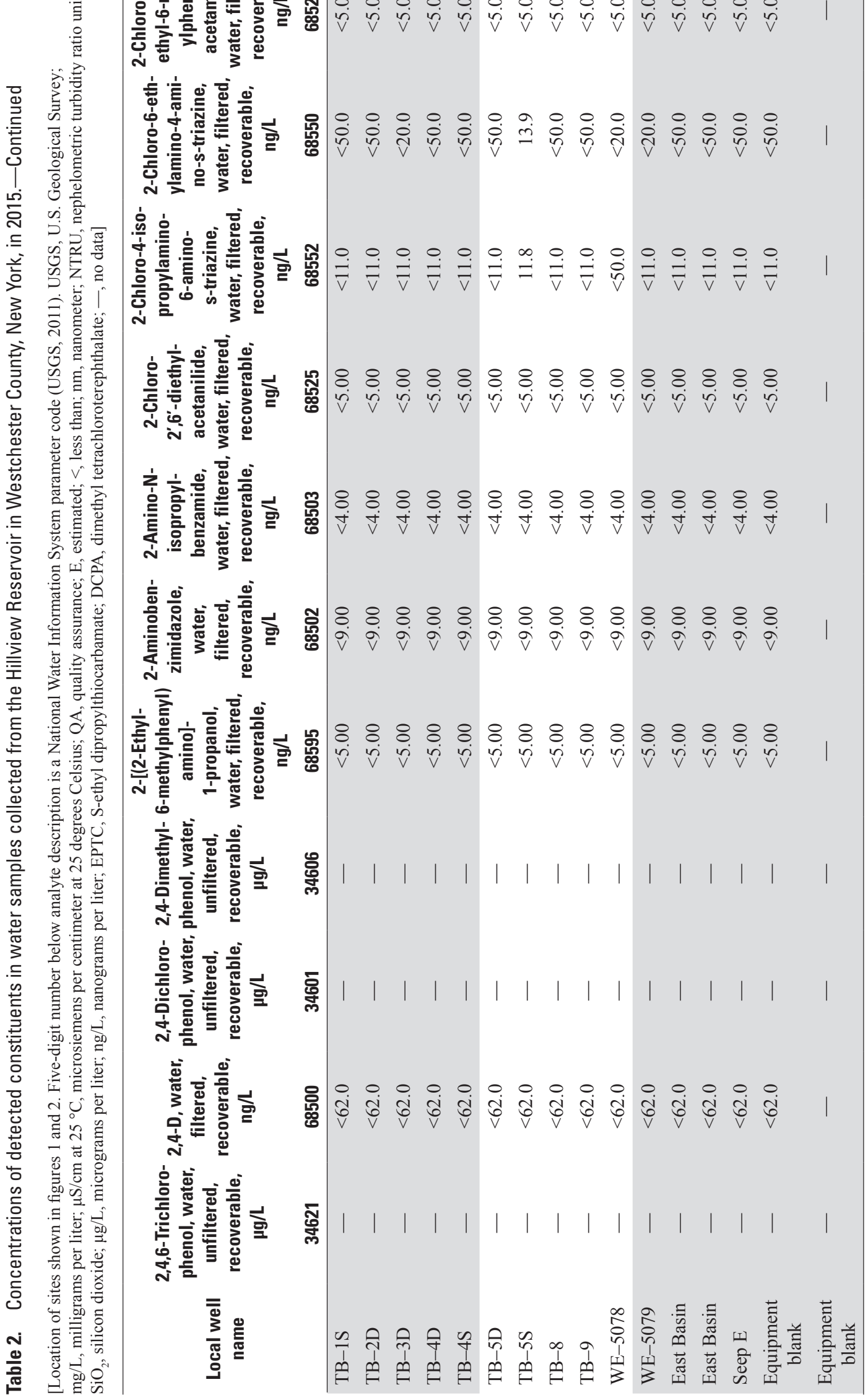




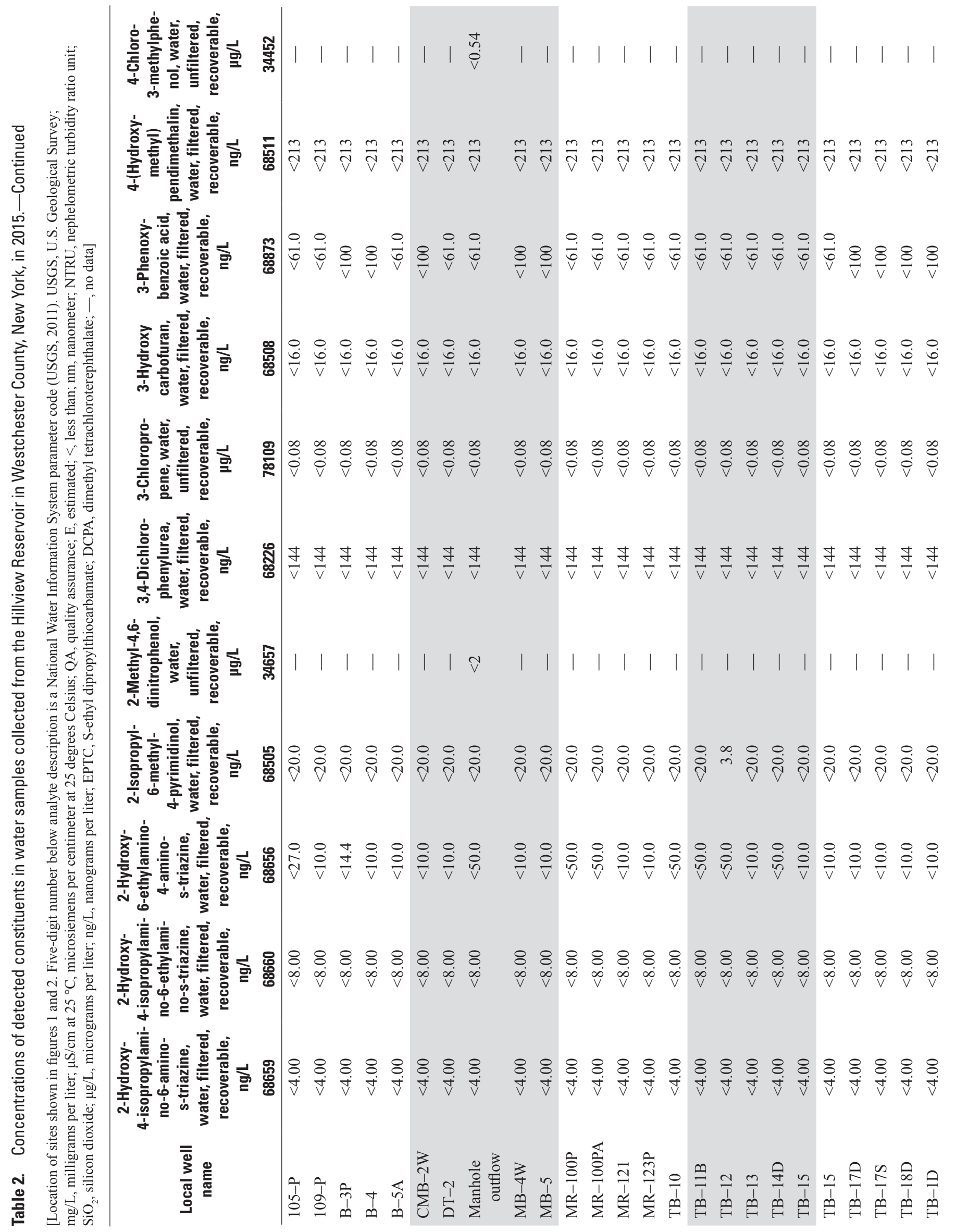




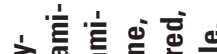

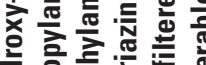

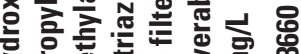

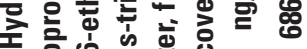

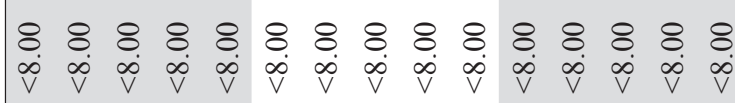

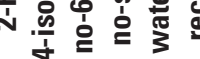




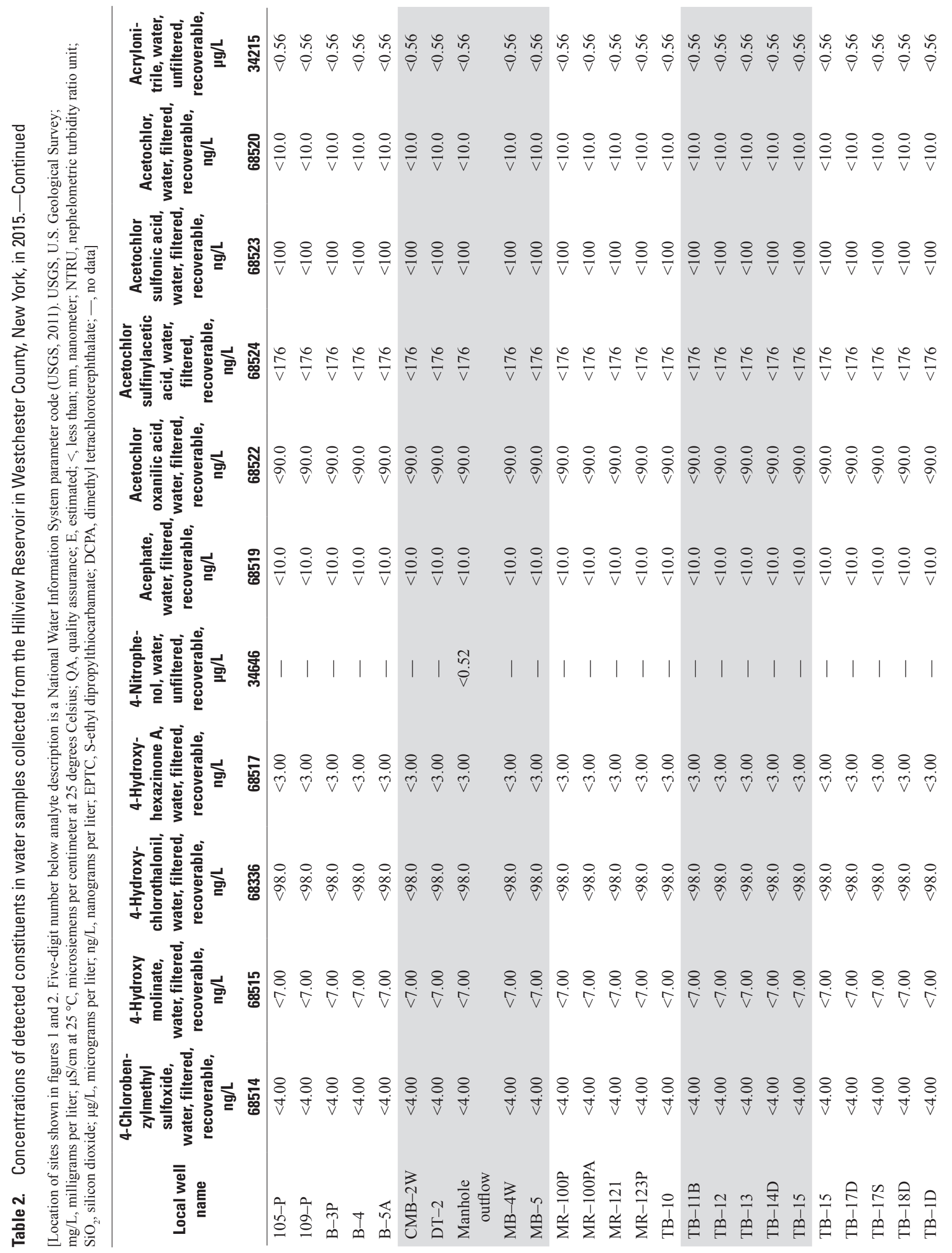




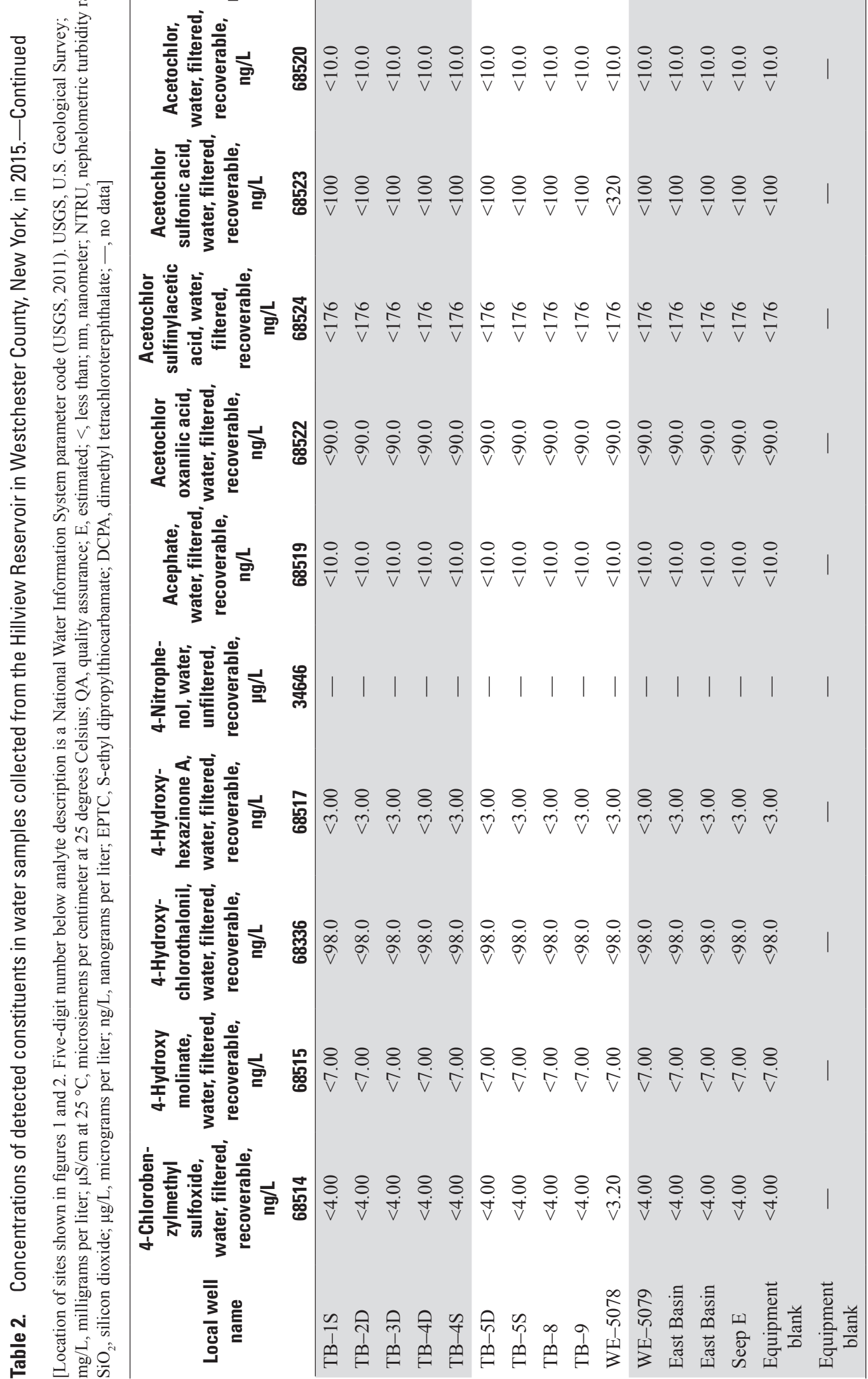




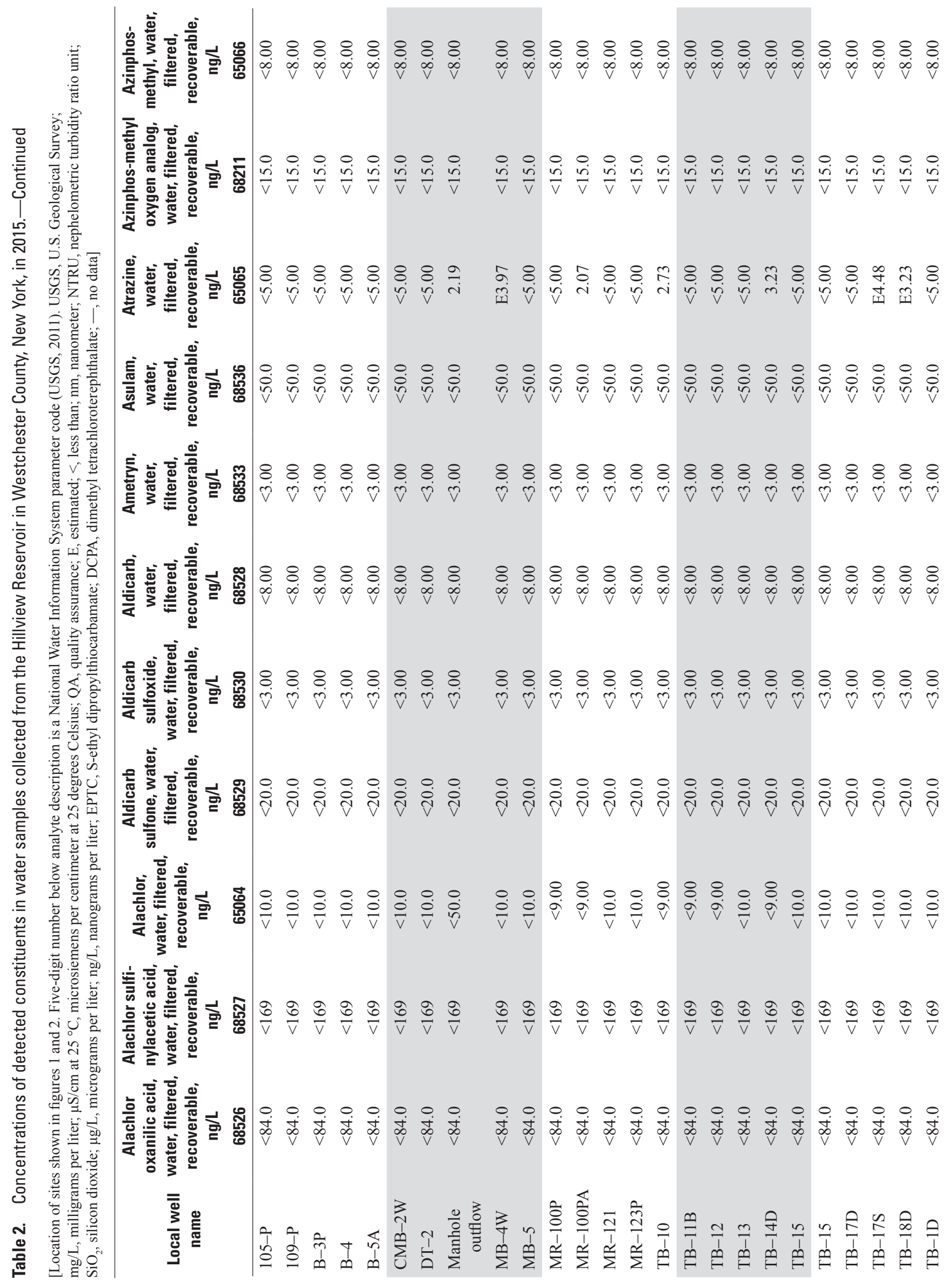




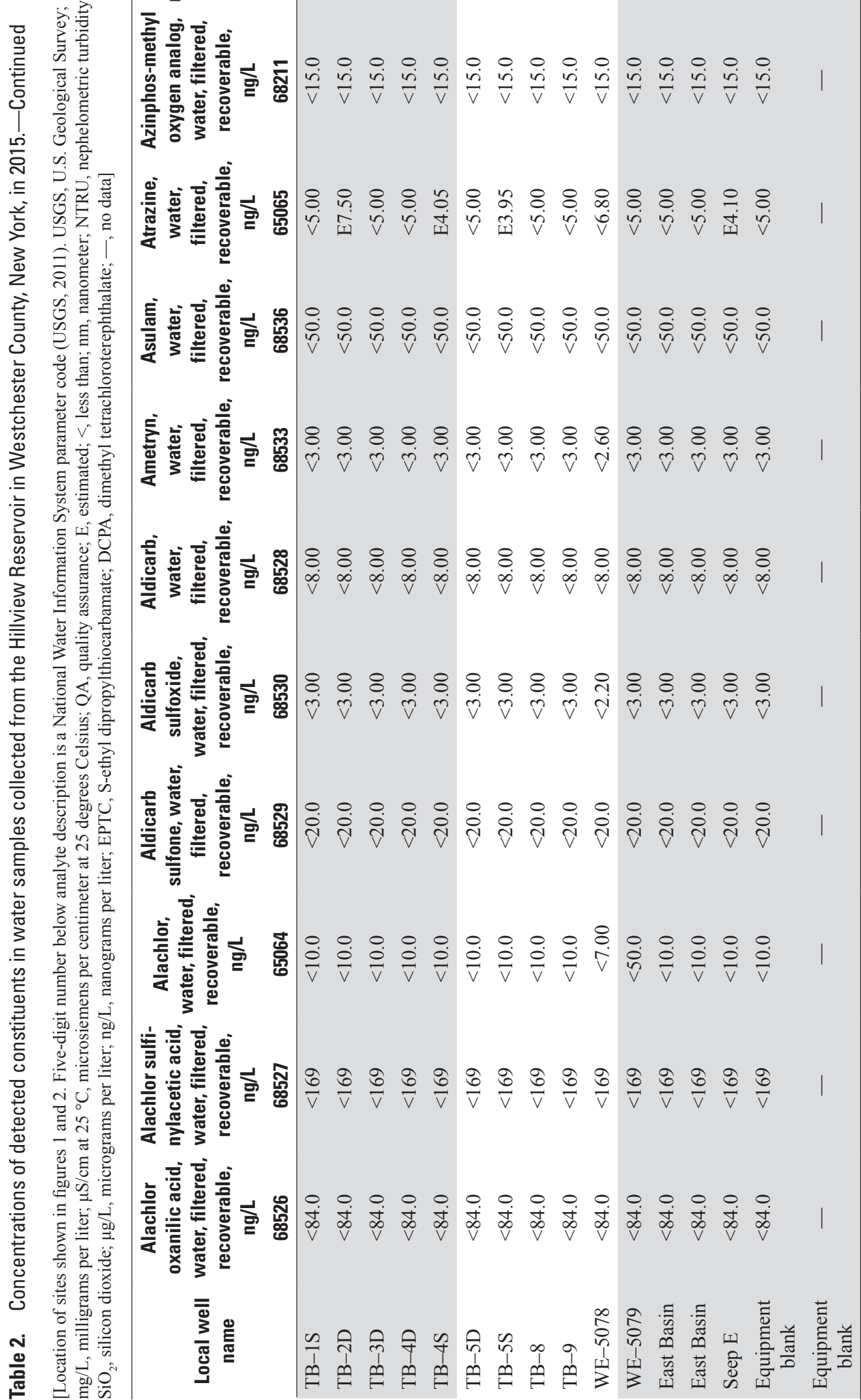




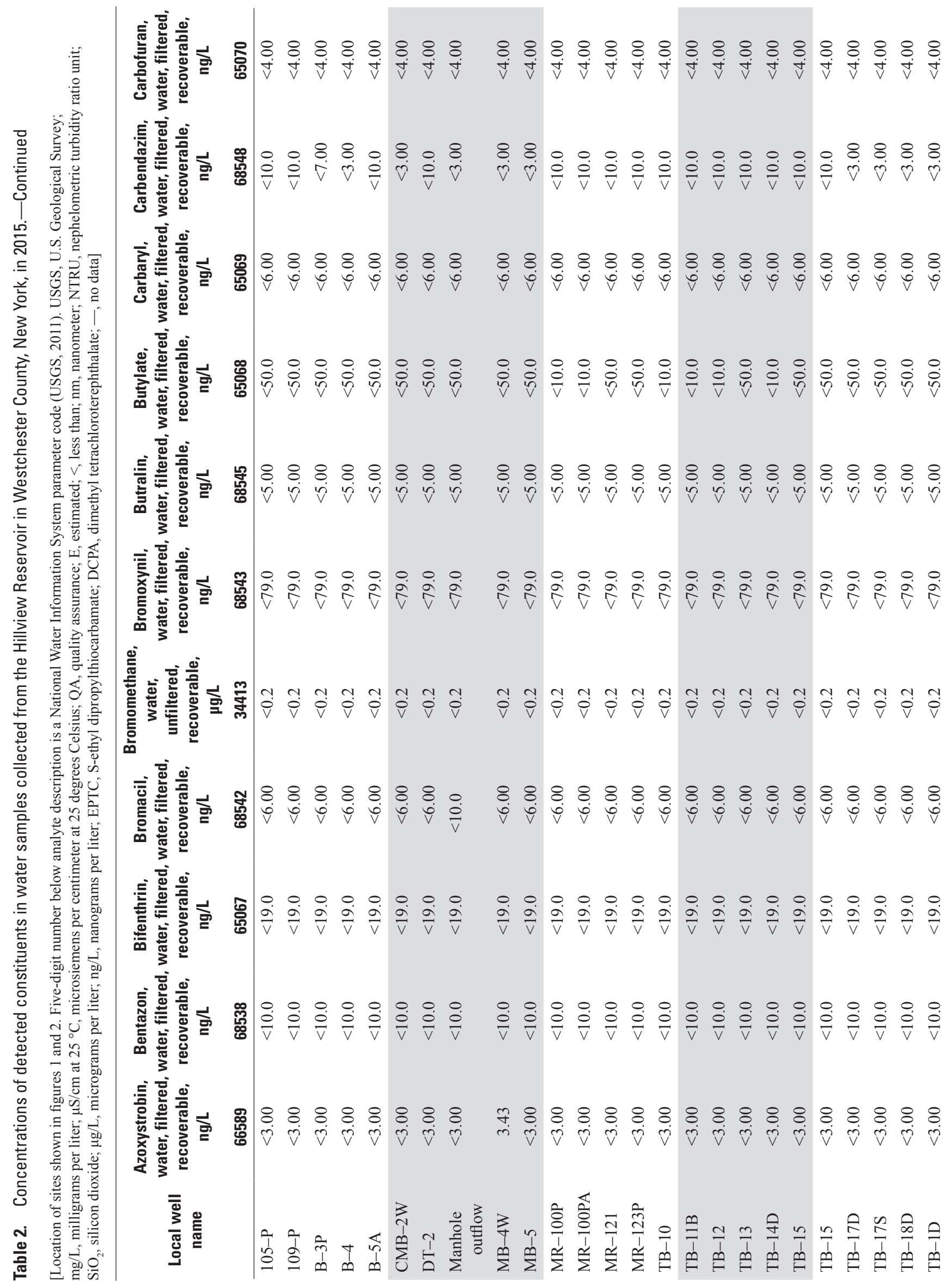




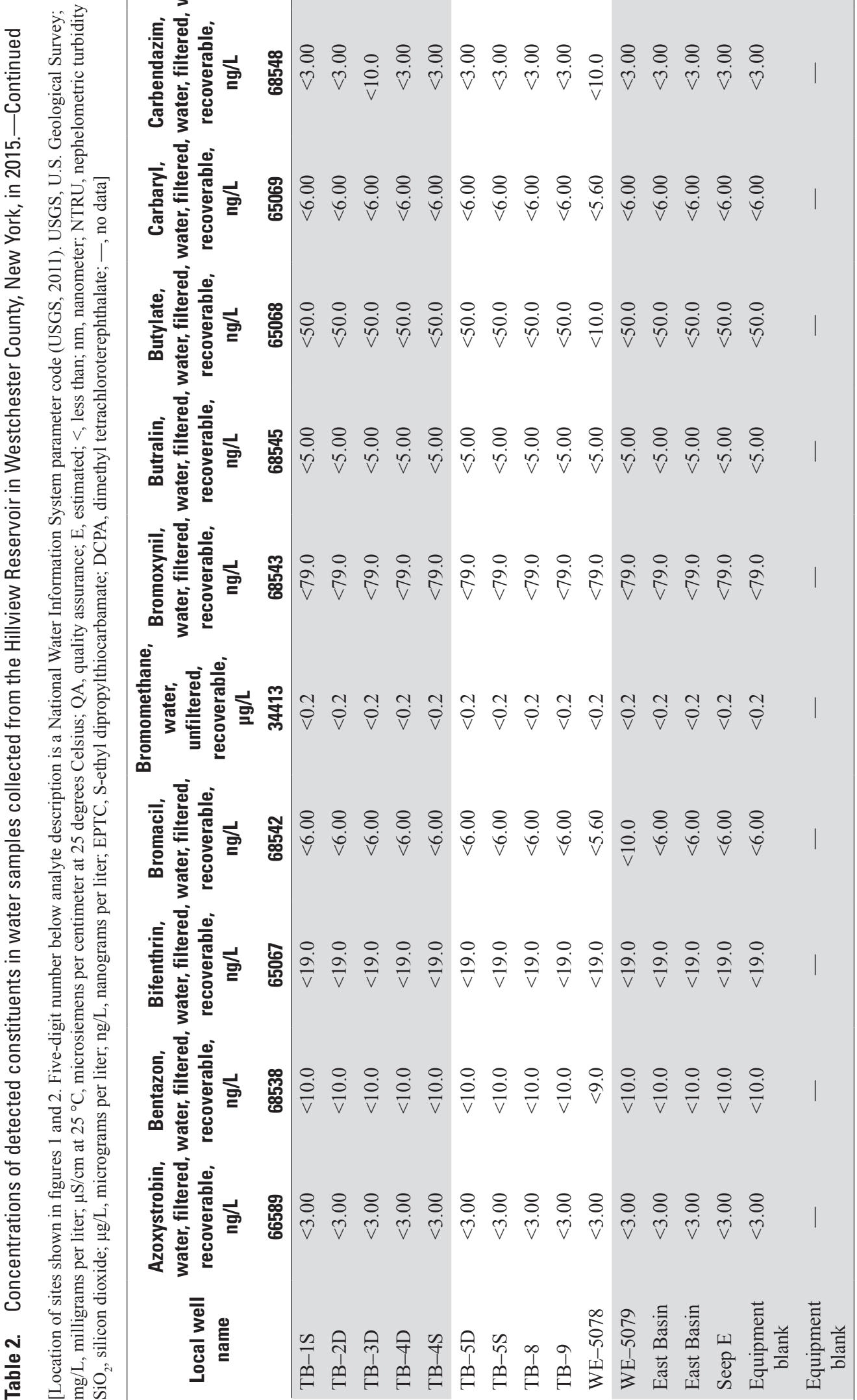




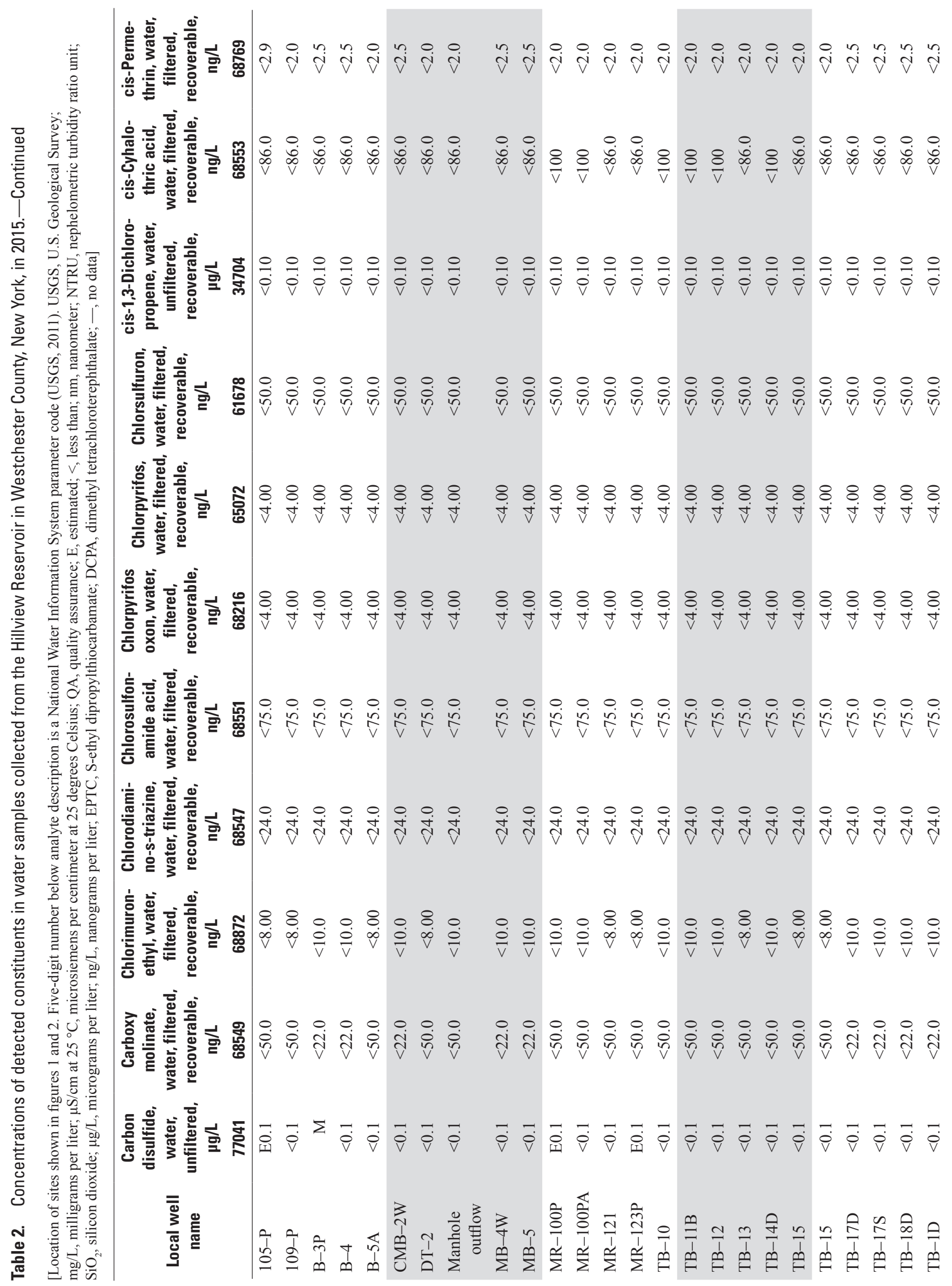




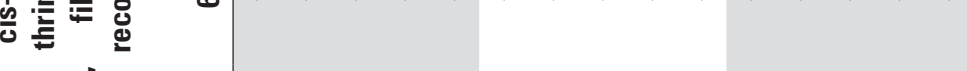

क

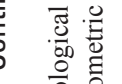

مे

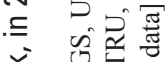

능

崩家节

文论带

恼

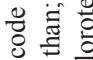

혼

要 $\mathrm{E}$

:

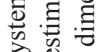

की से

\&

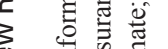

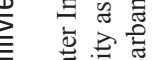

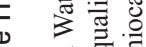

‡ 플

要

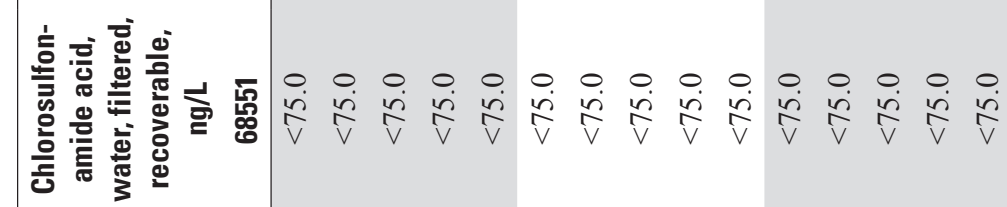

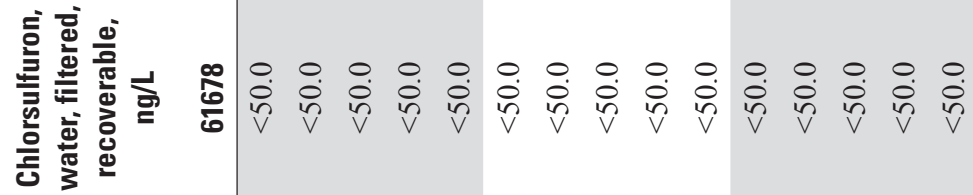

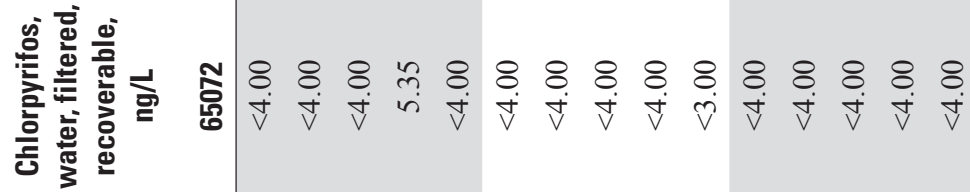

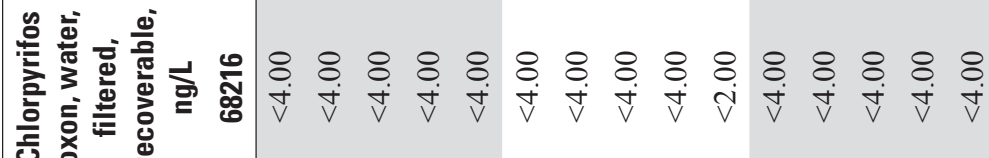

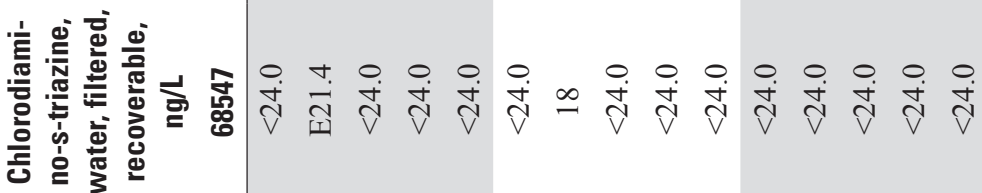

淧

3.

它

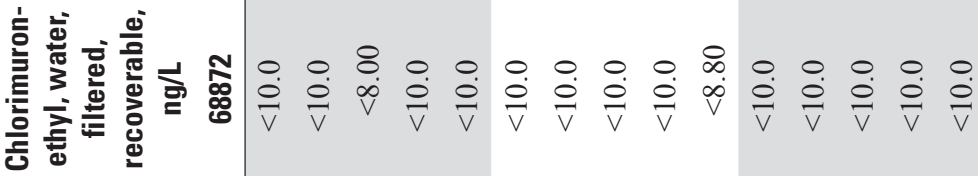

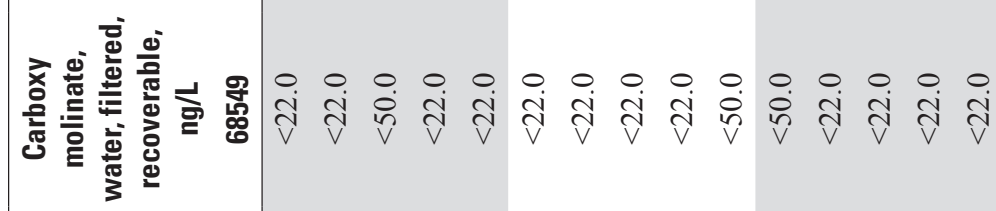

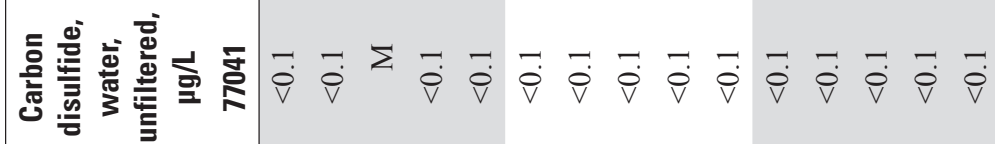

离

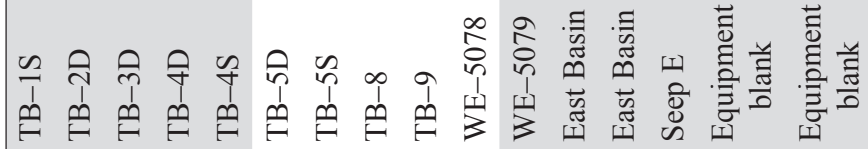




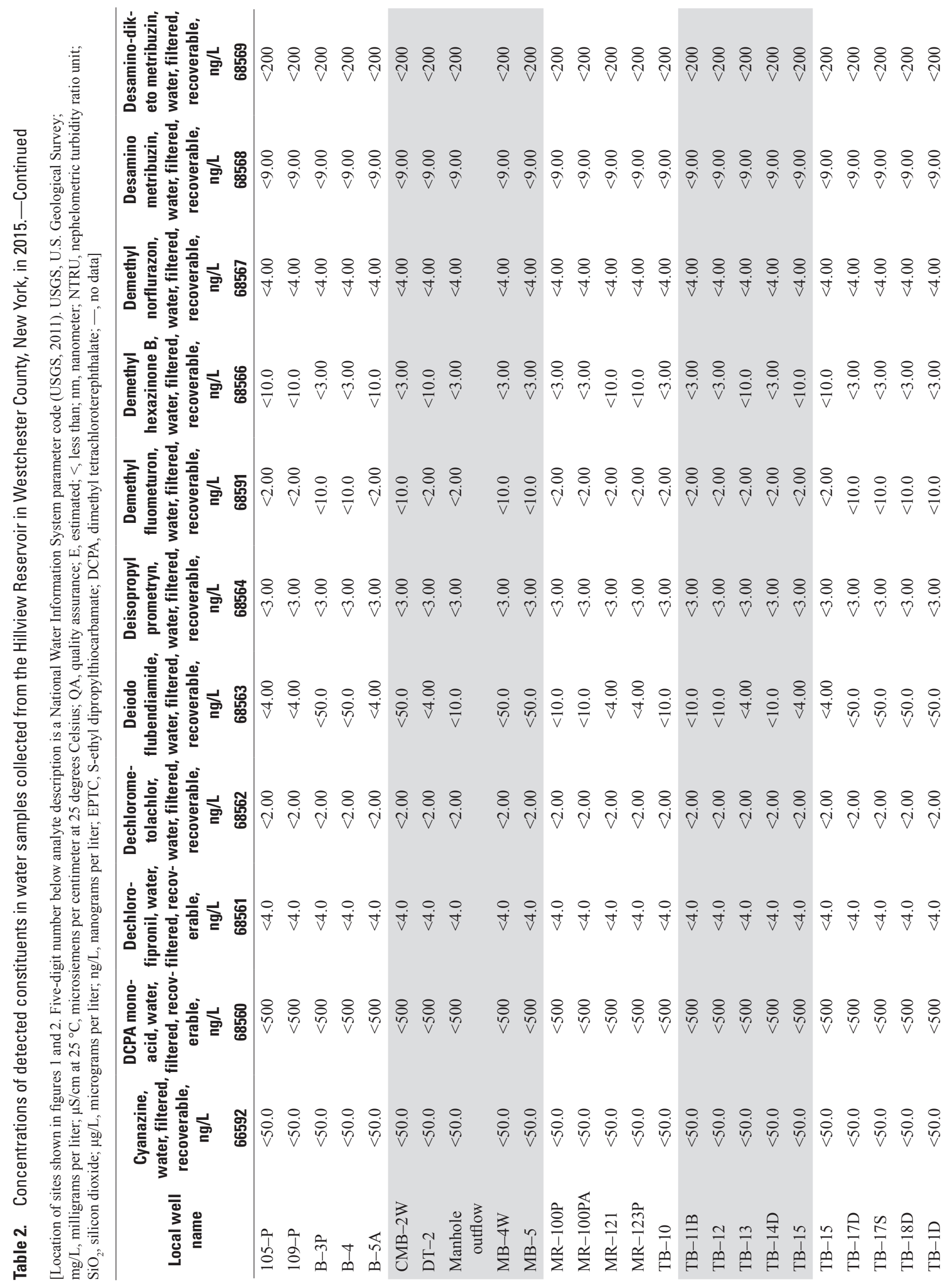




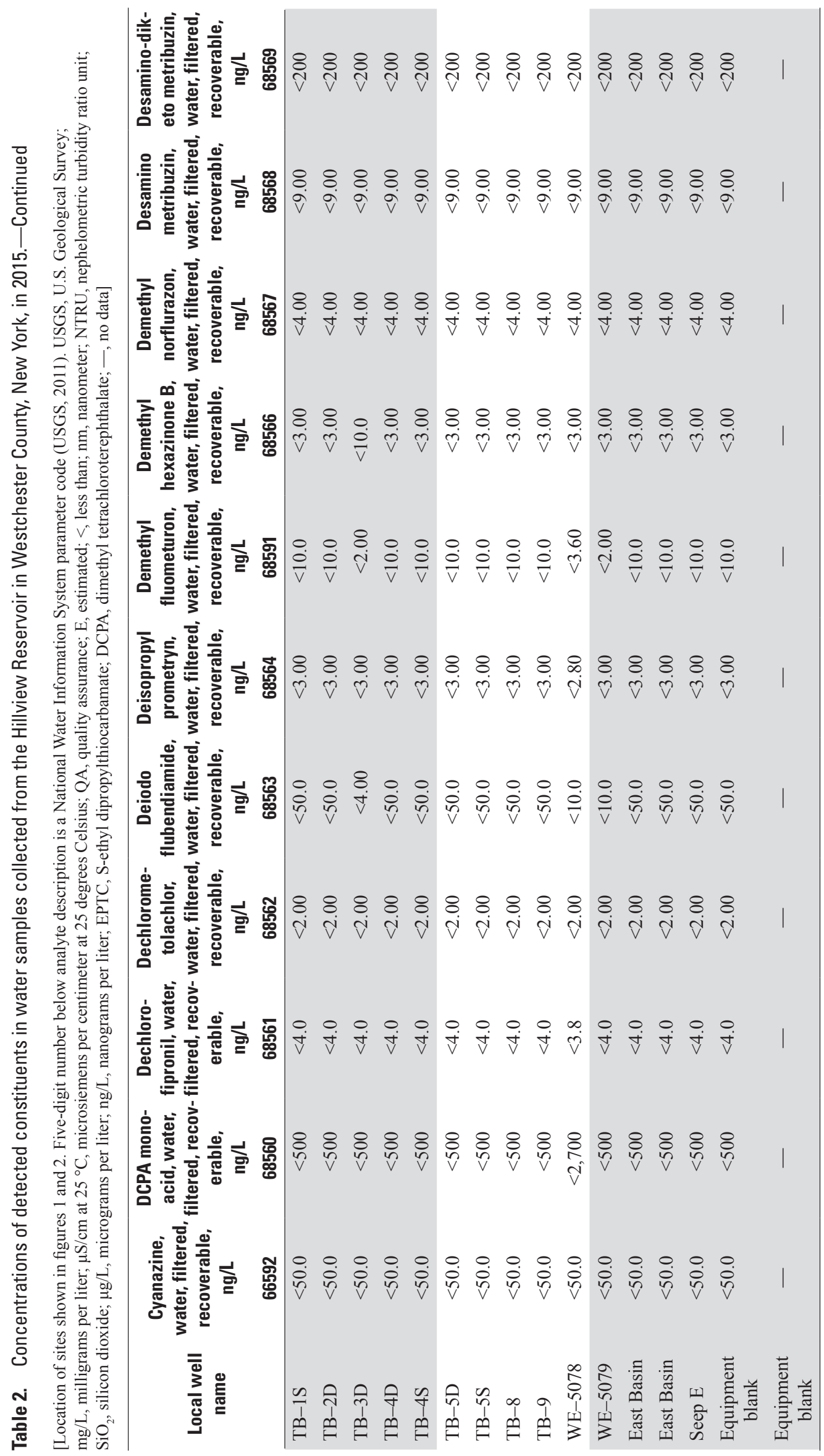




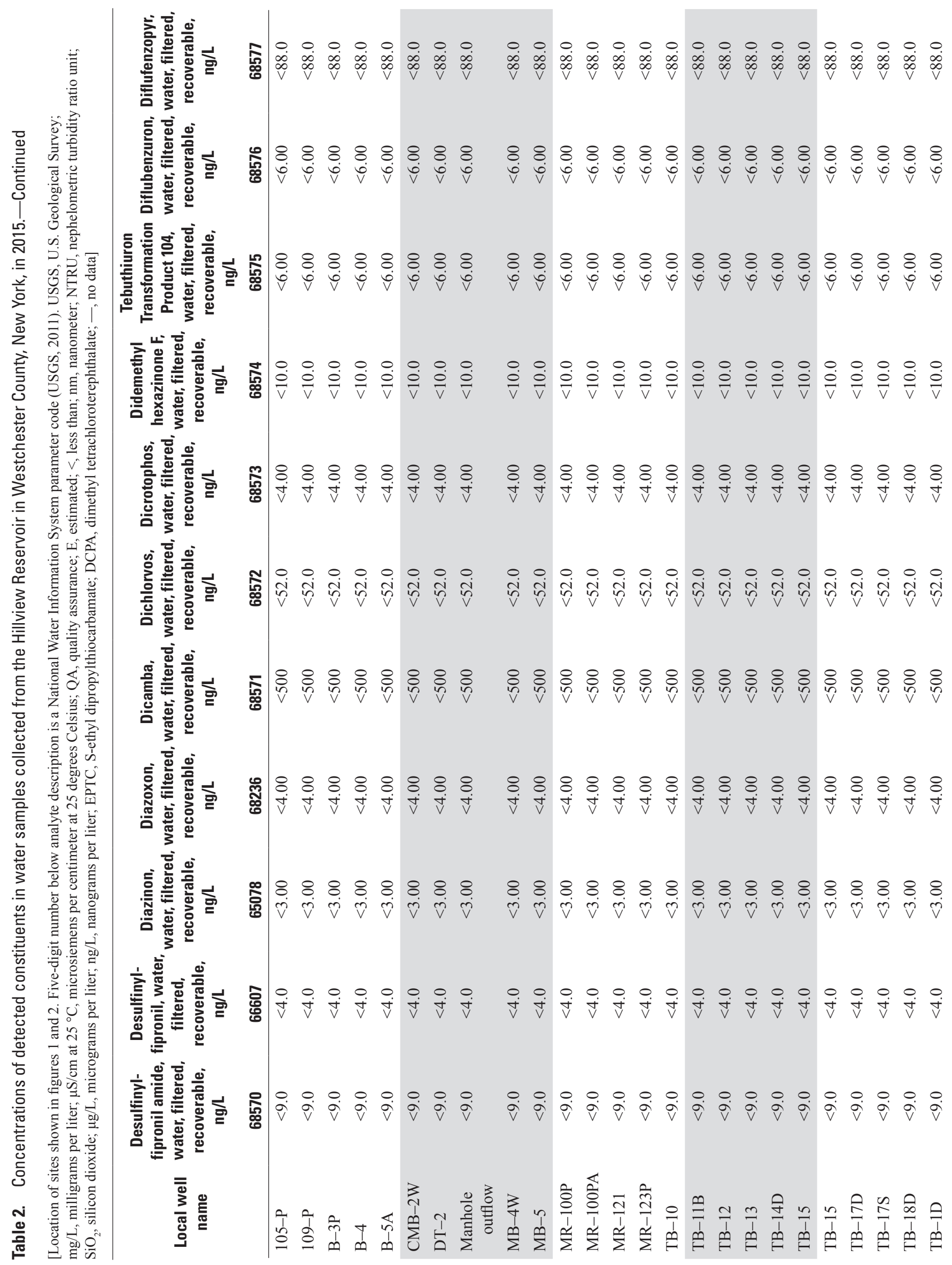




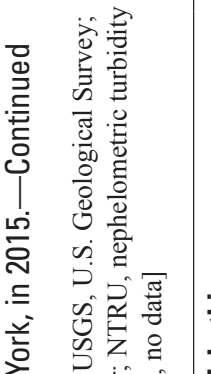

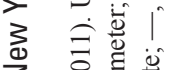

言要

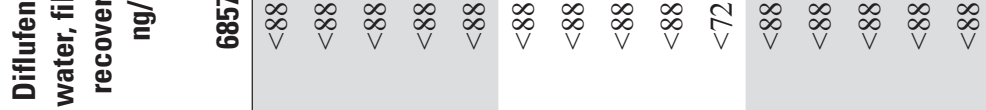

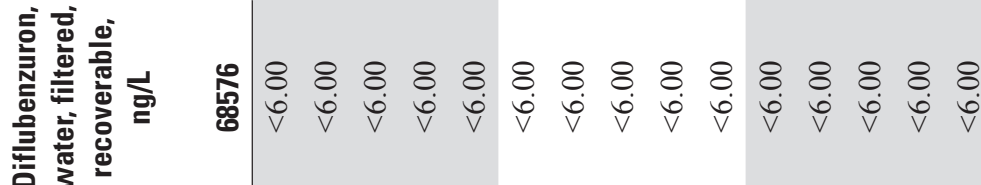

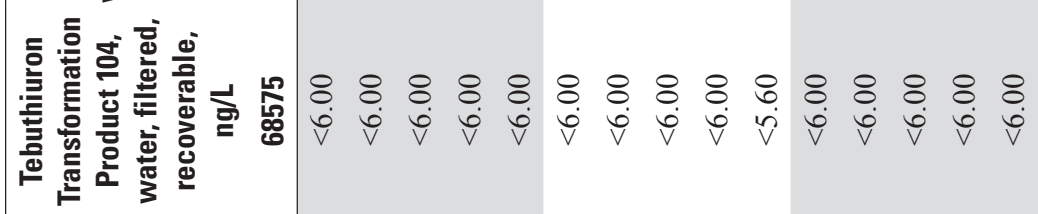

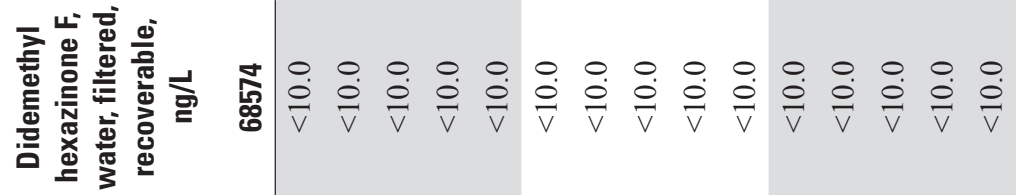

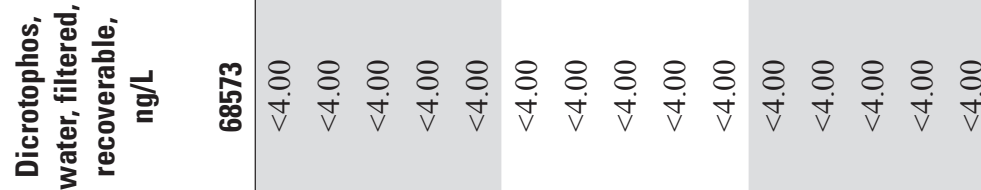
远

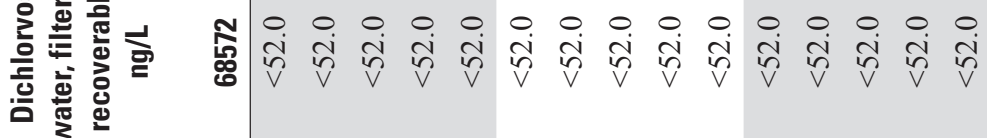
요

혈

击 


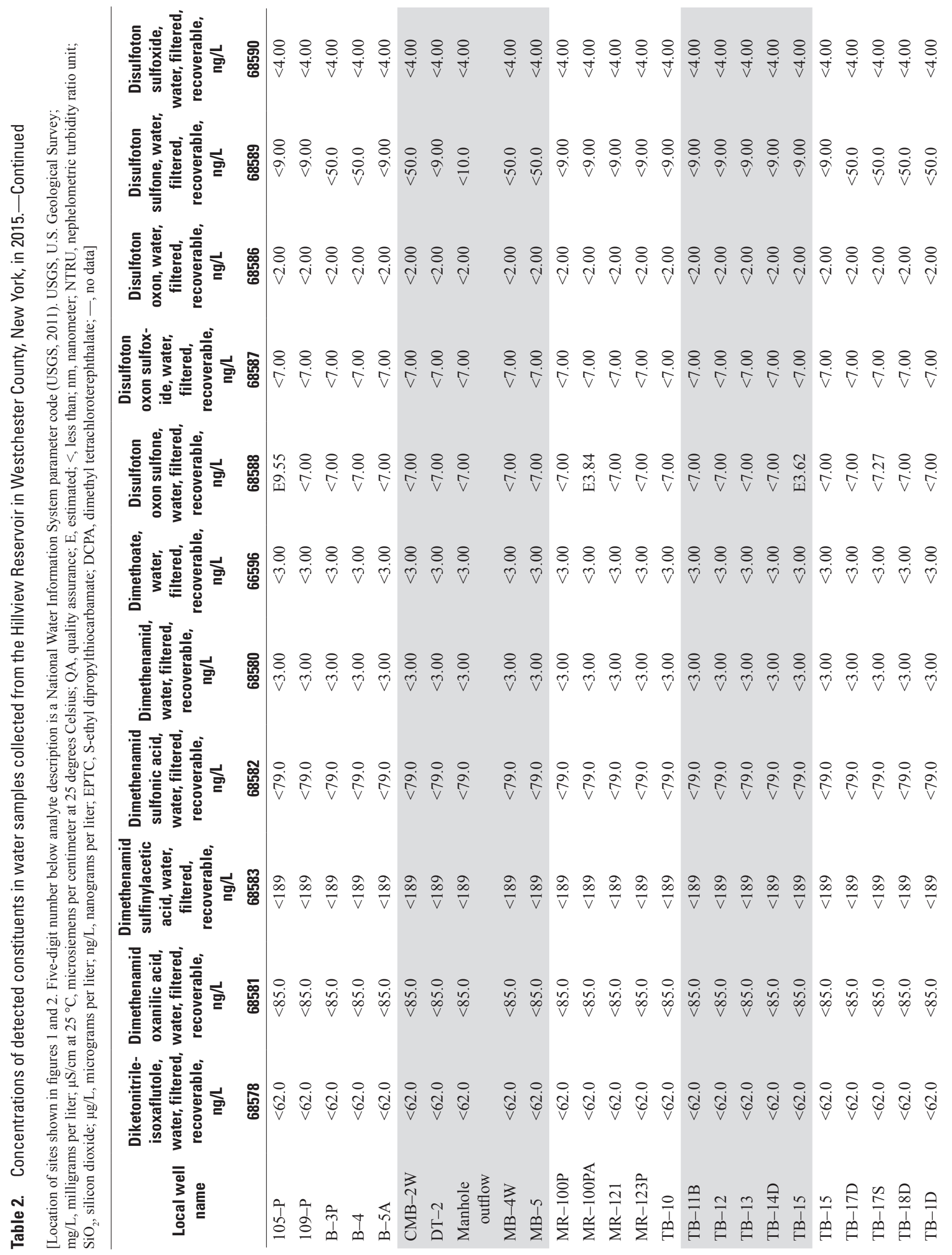




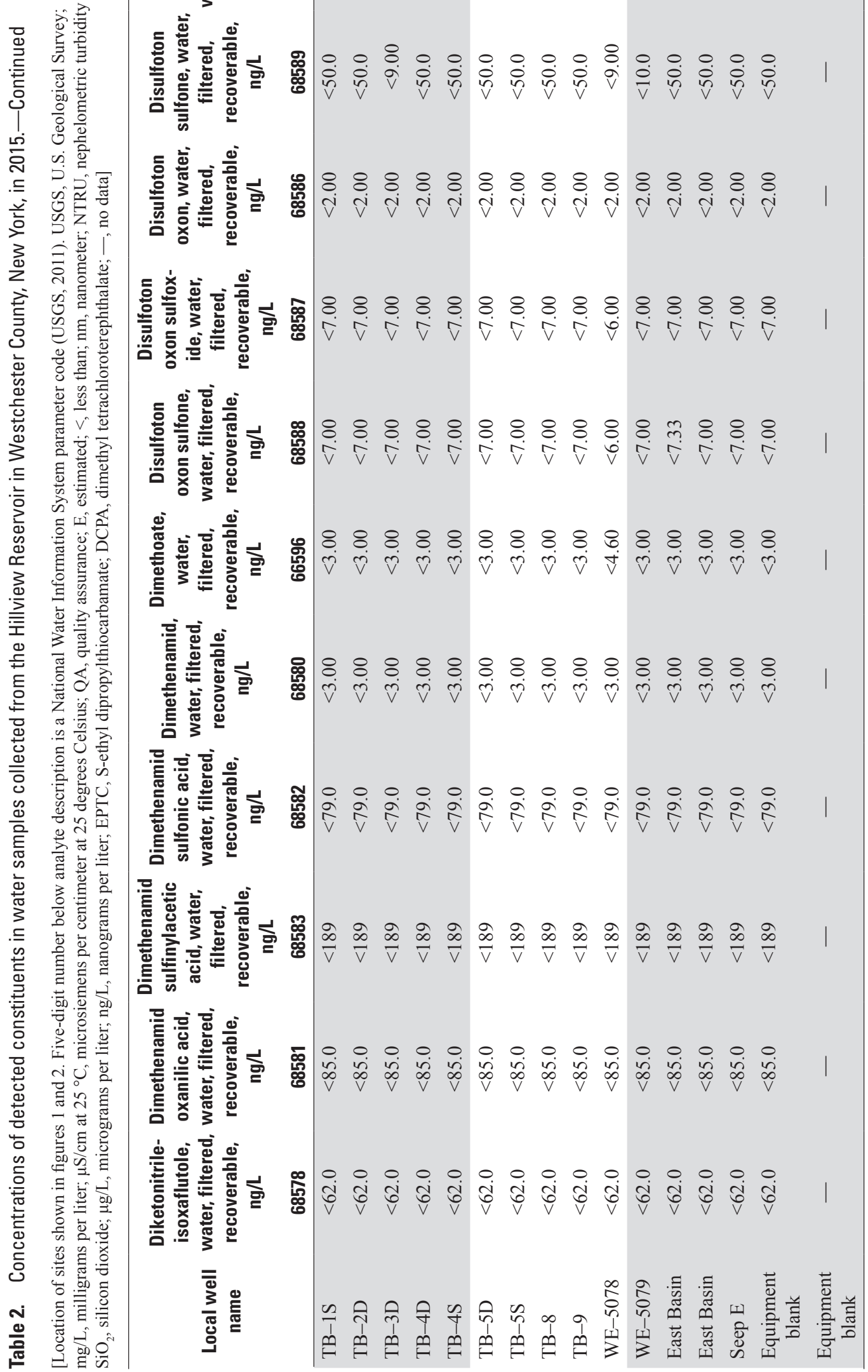




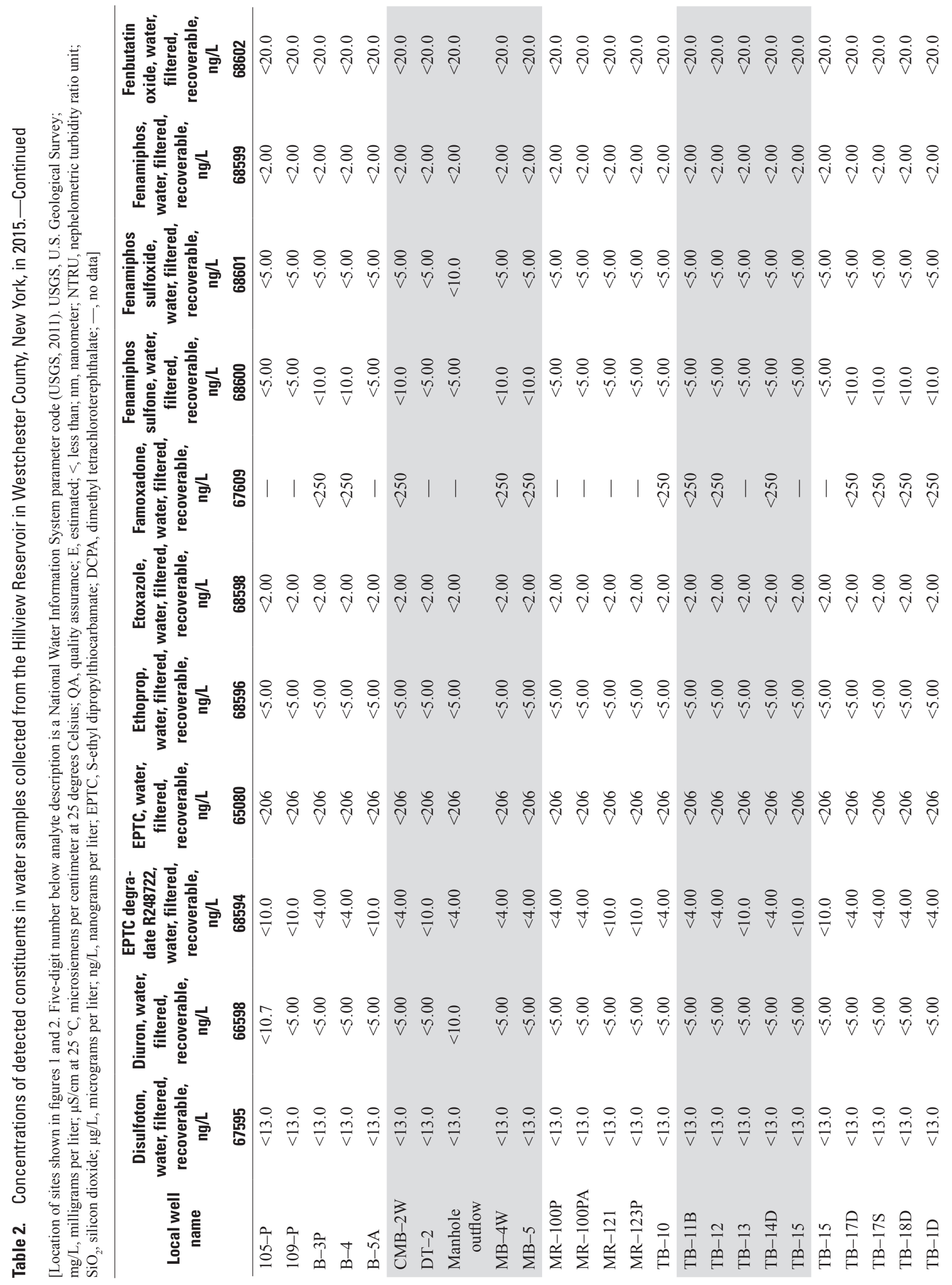




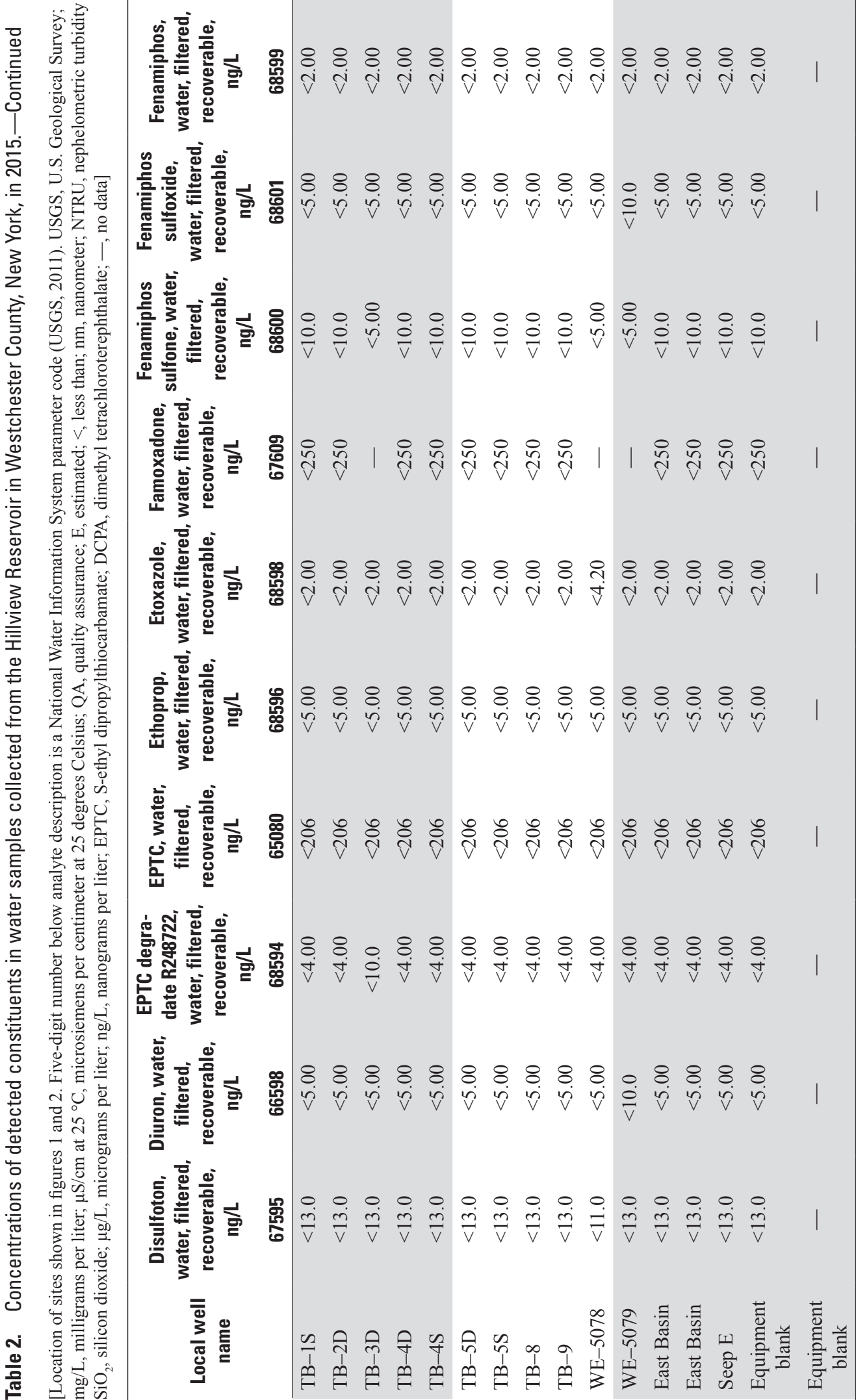




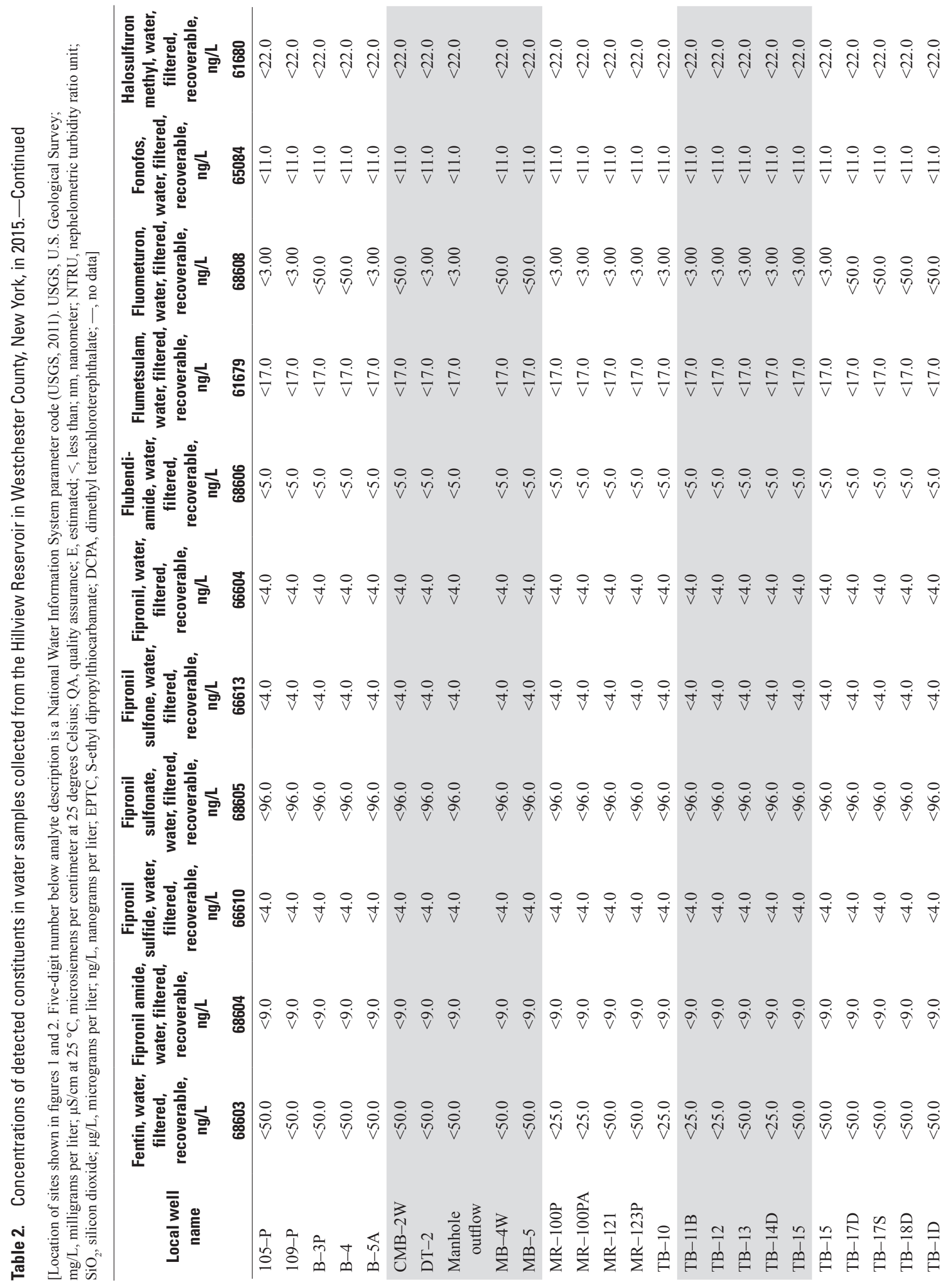




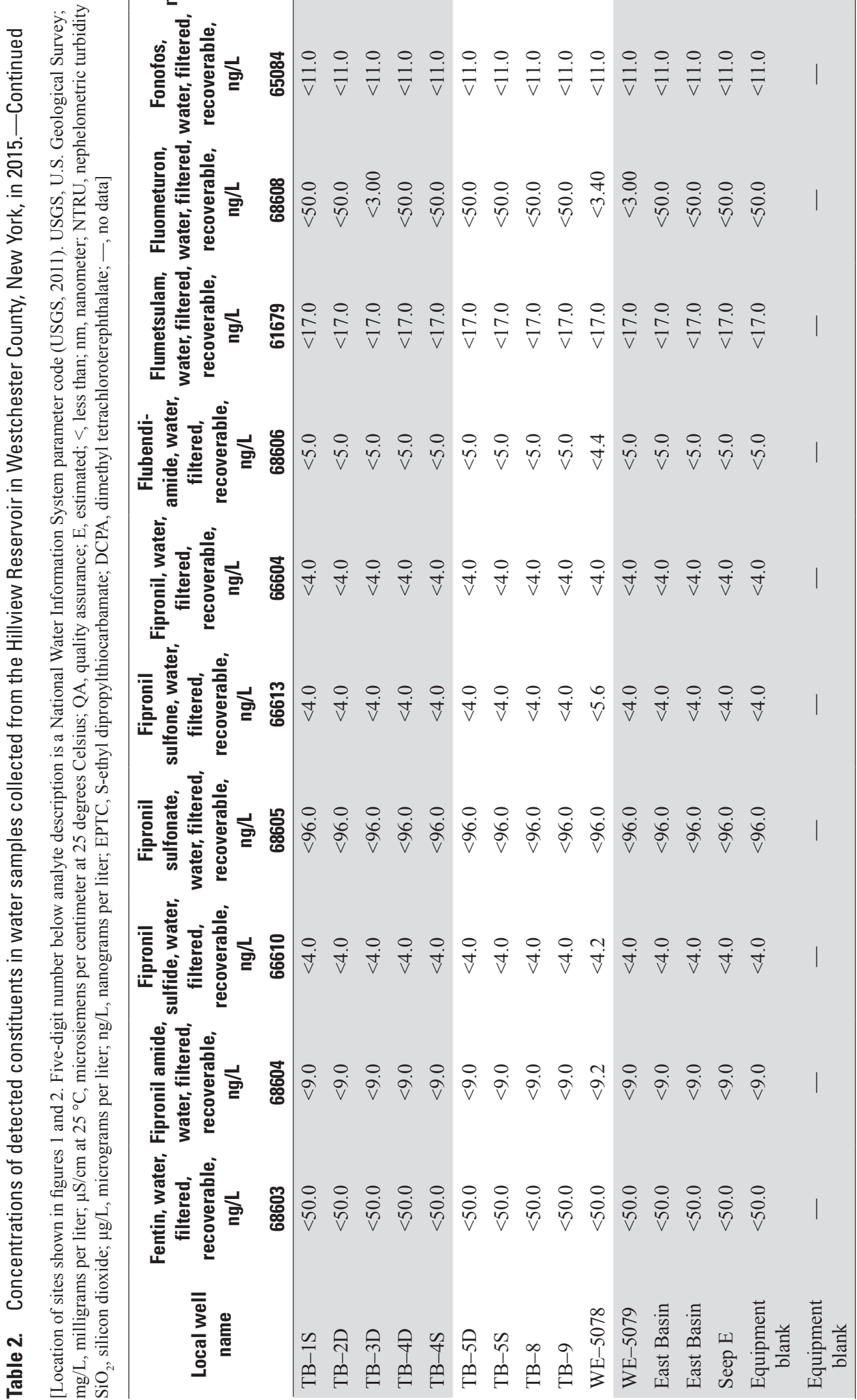




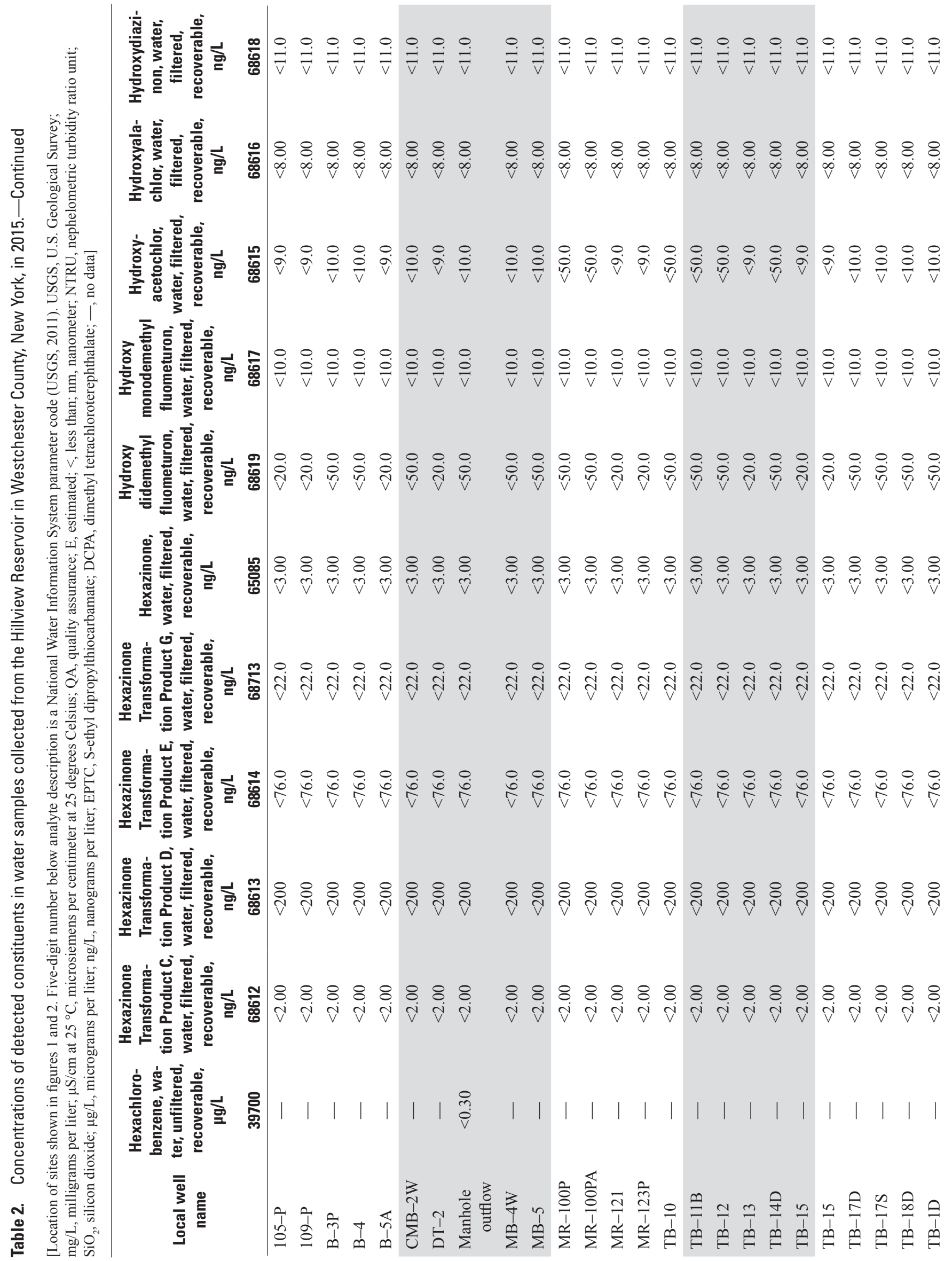




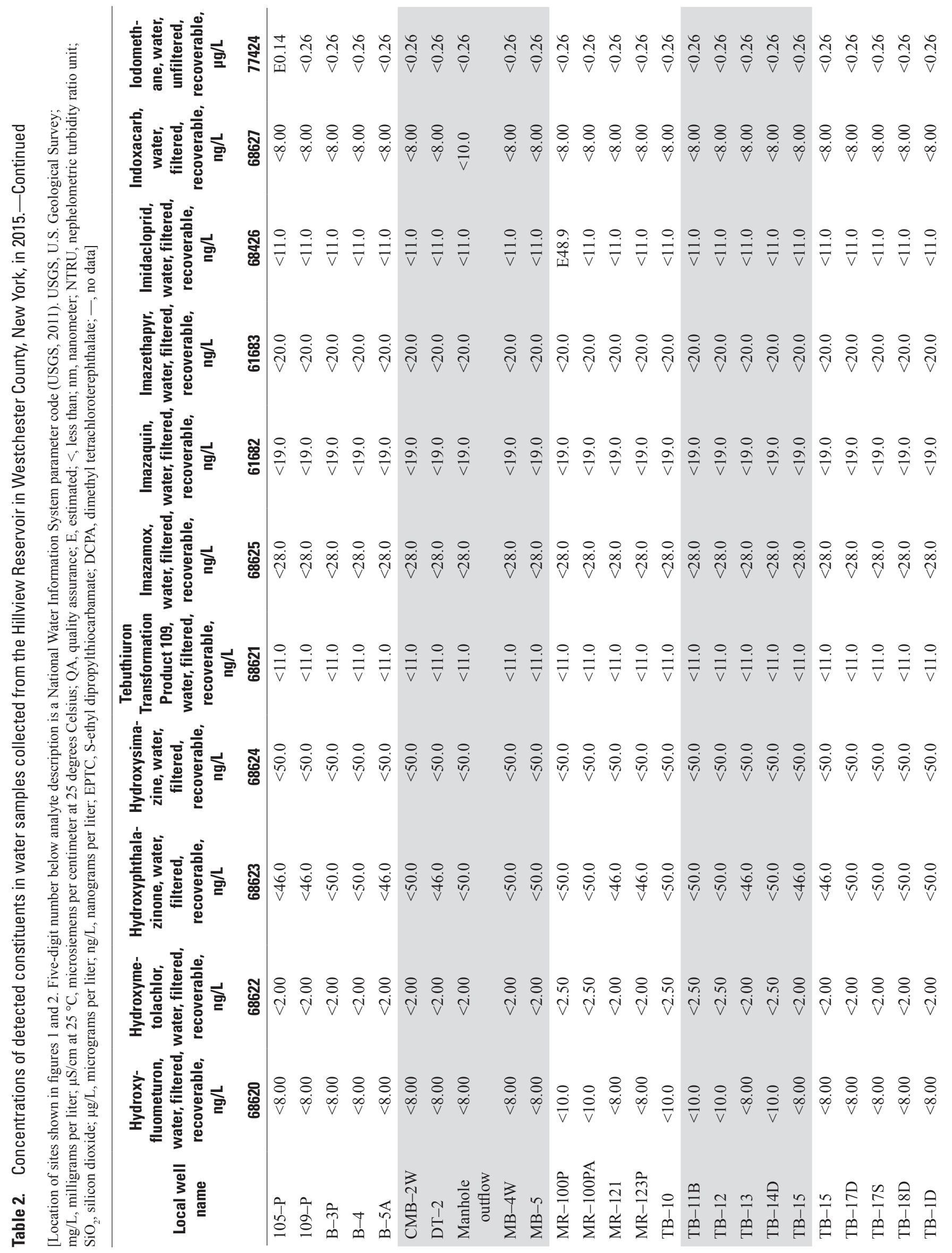




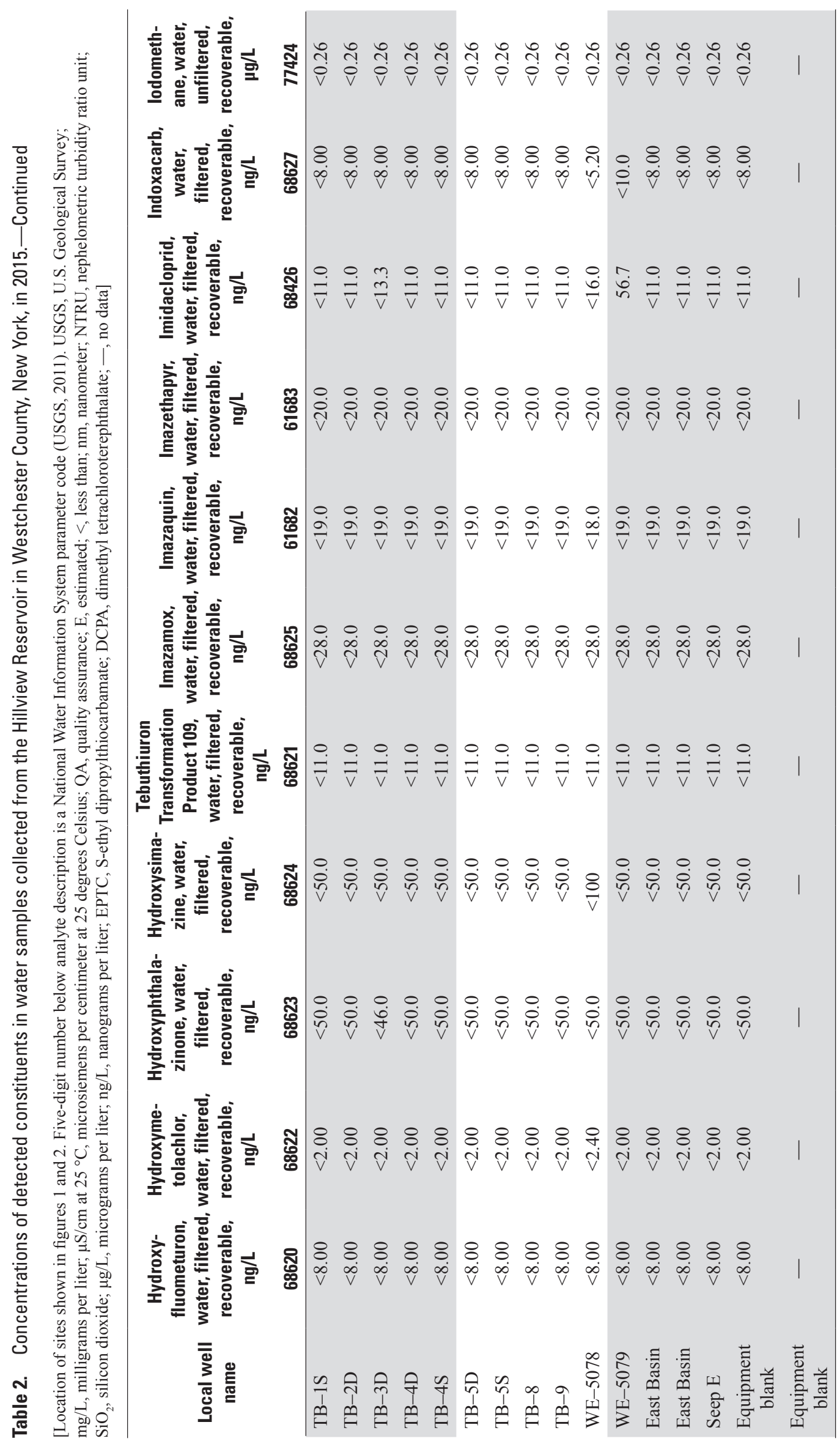




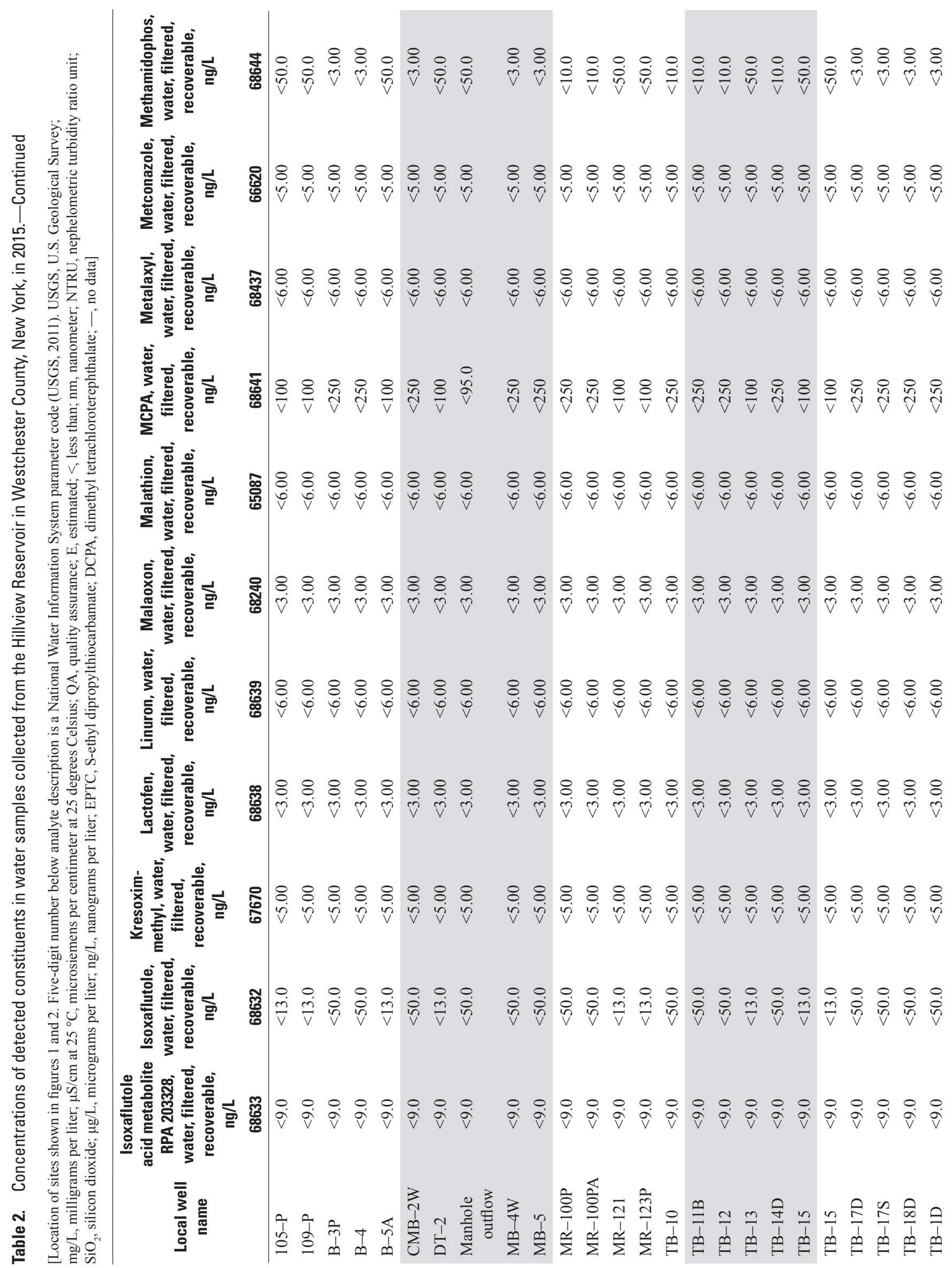




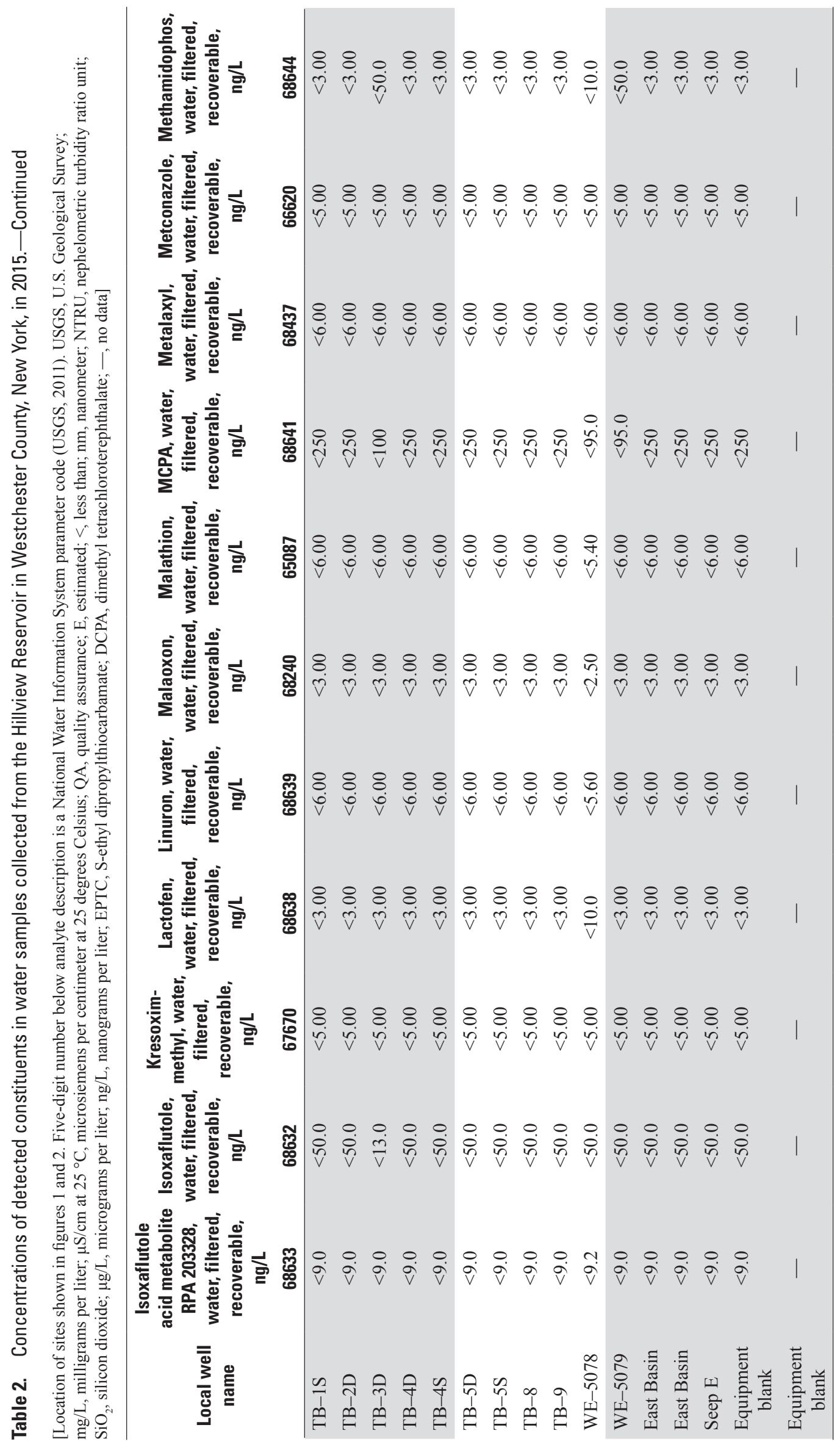




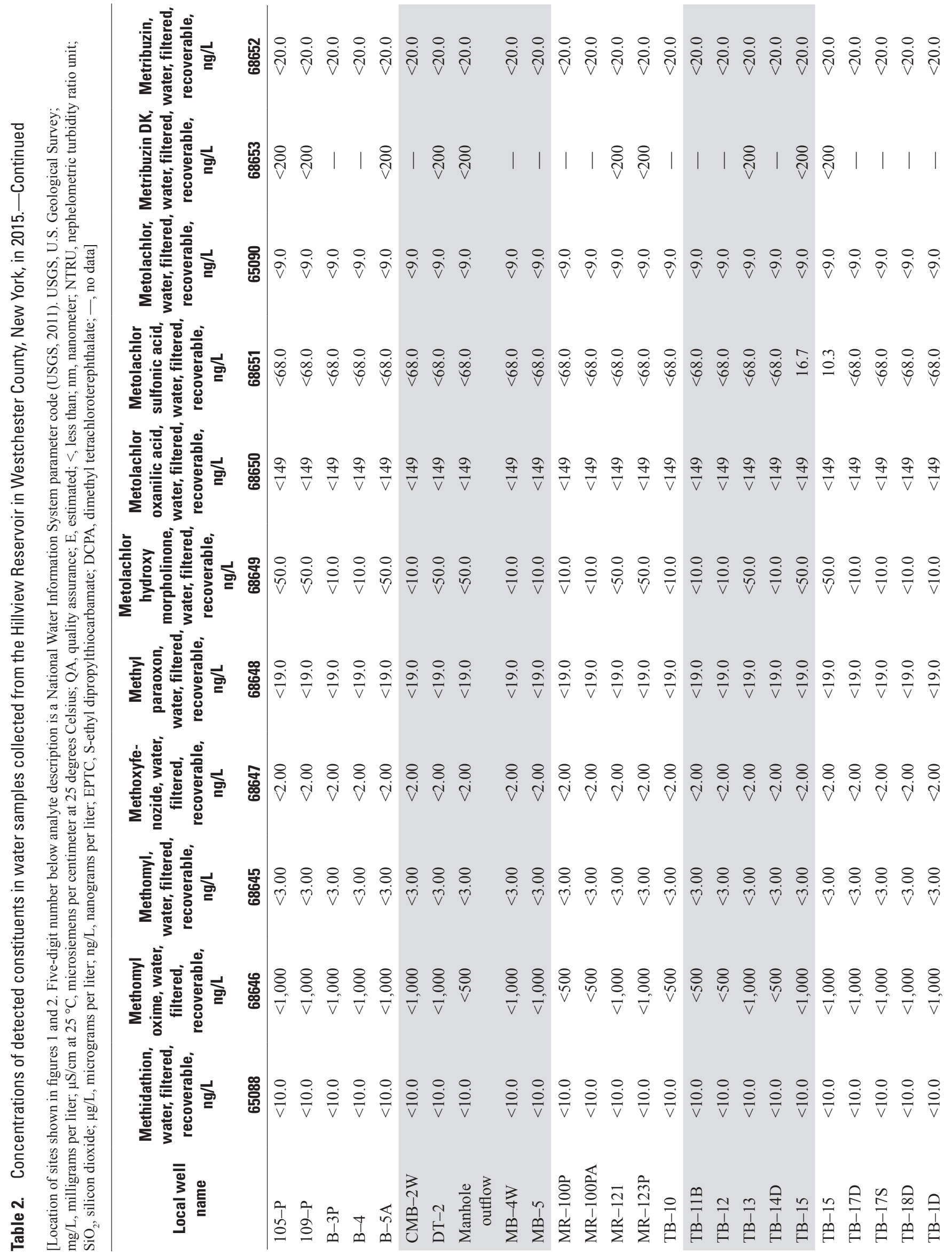




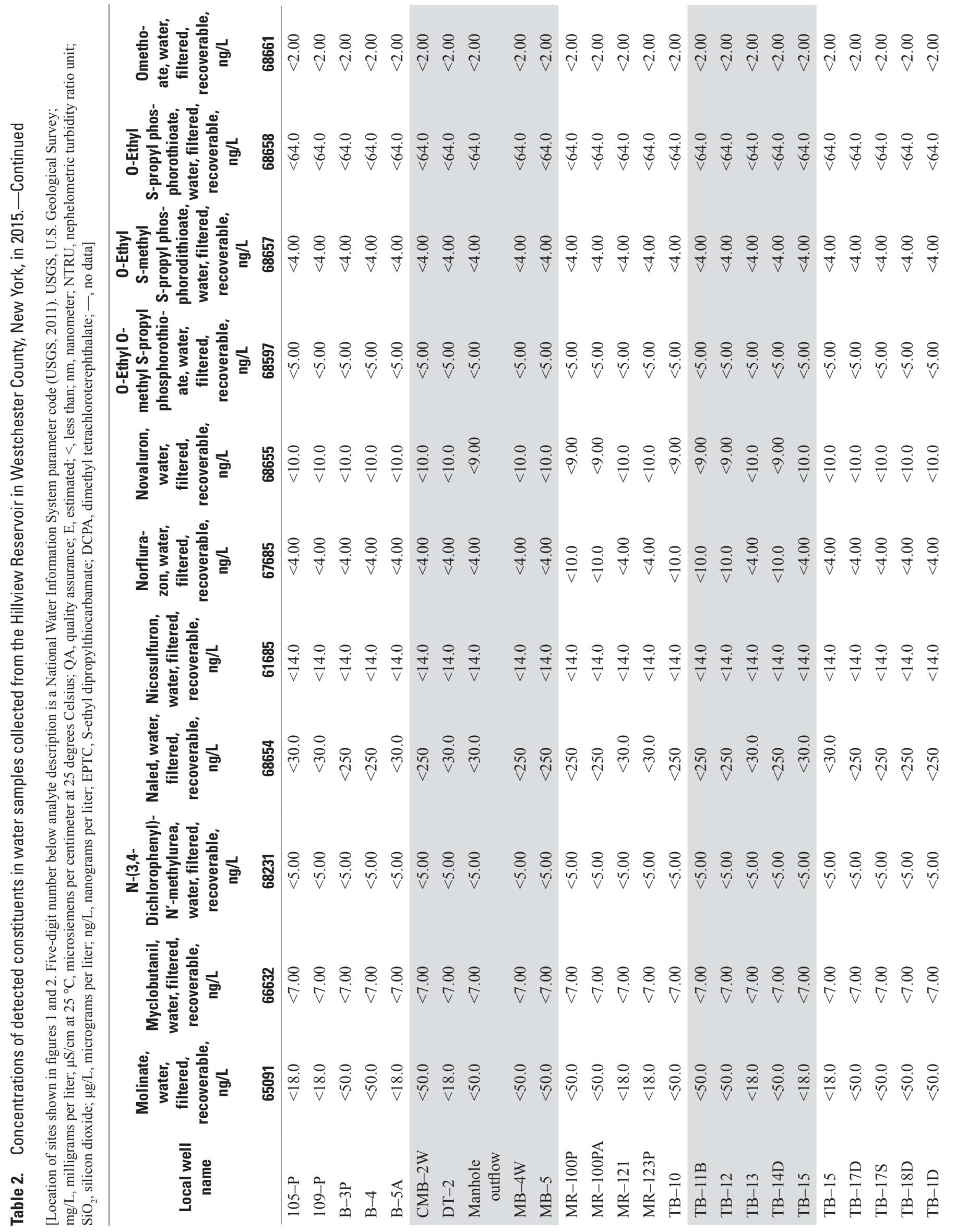




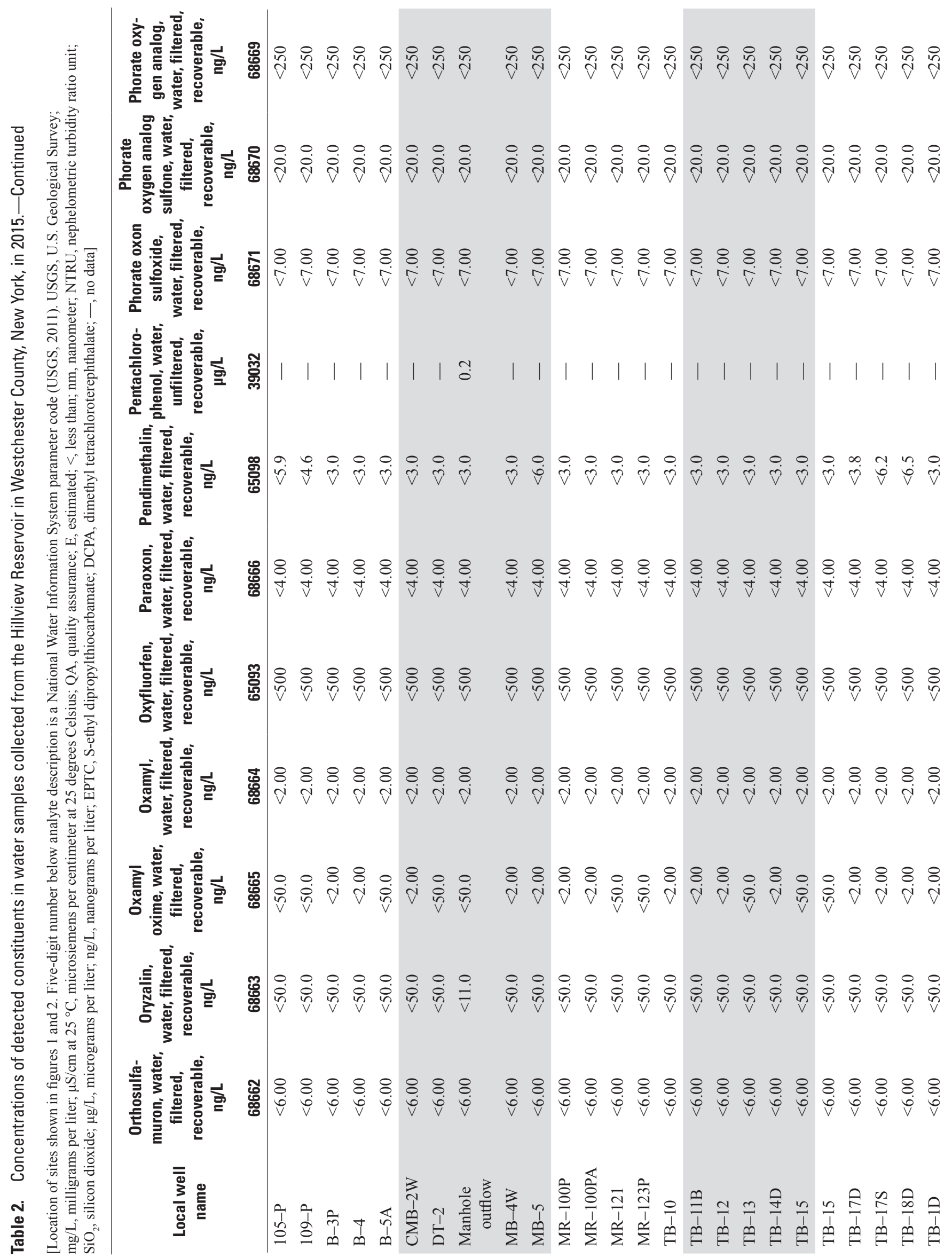




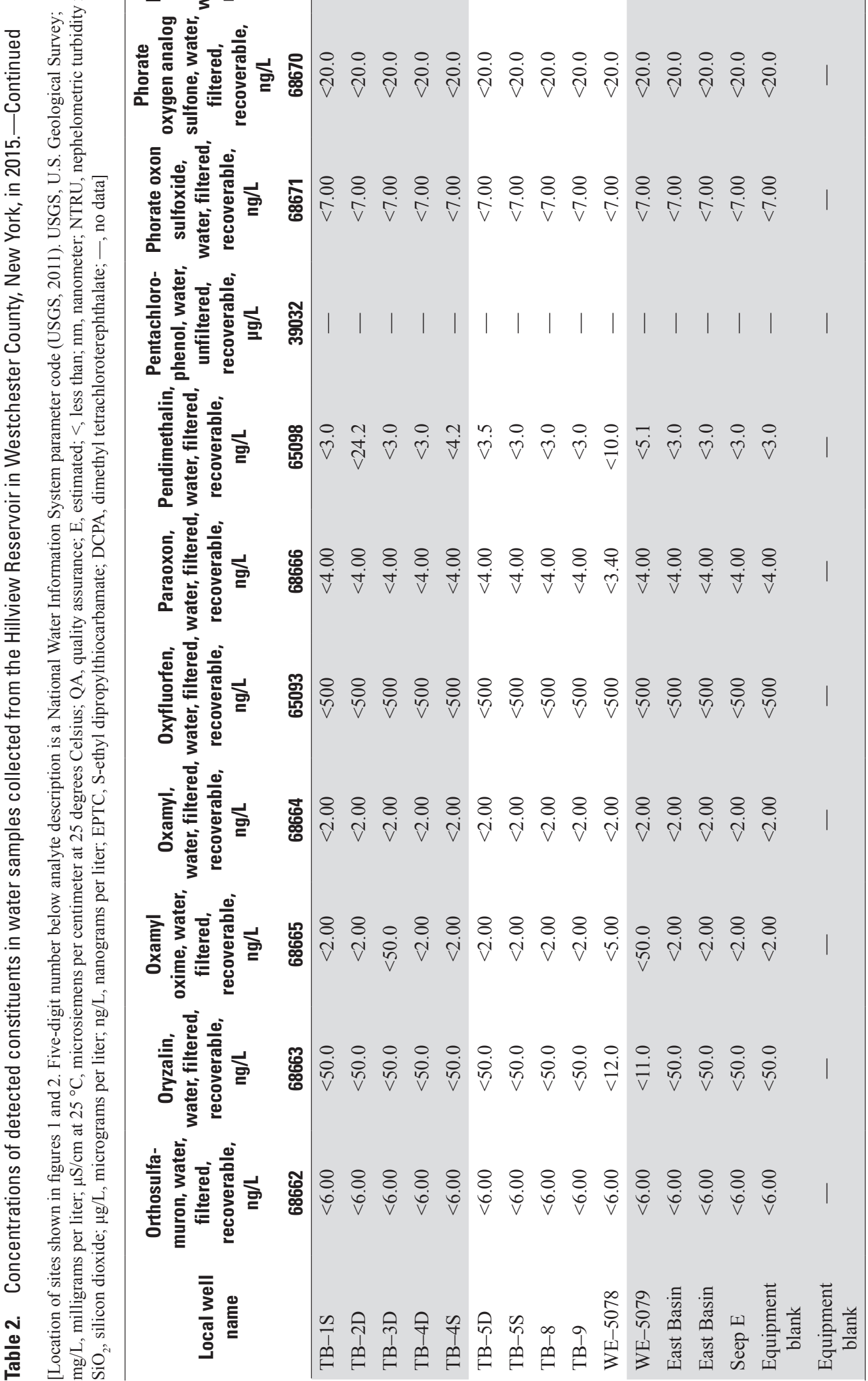




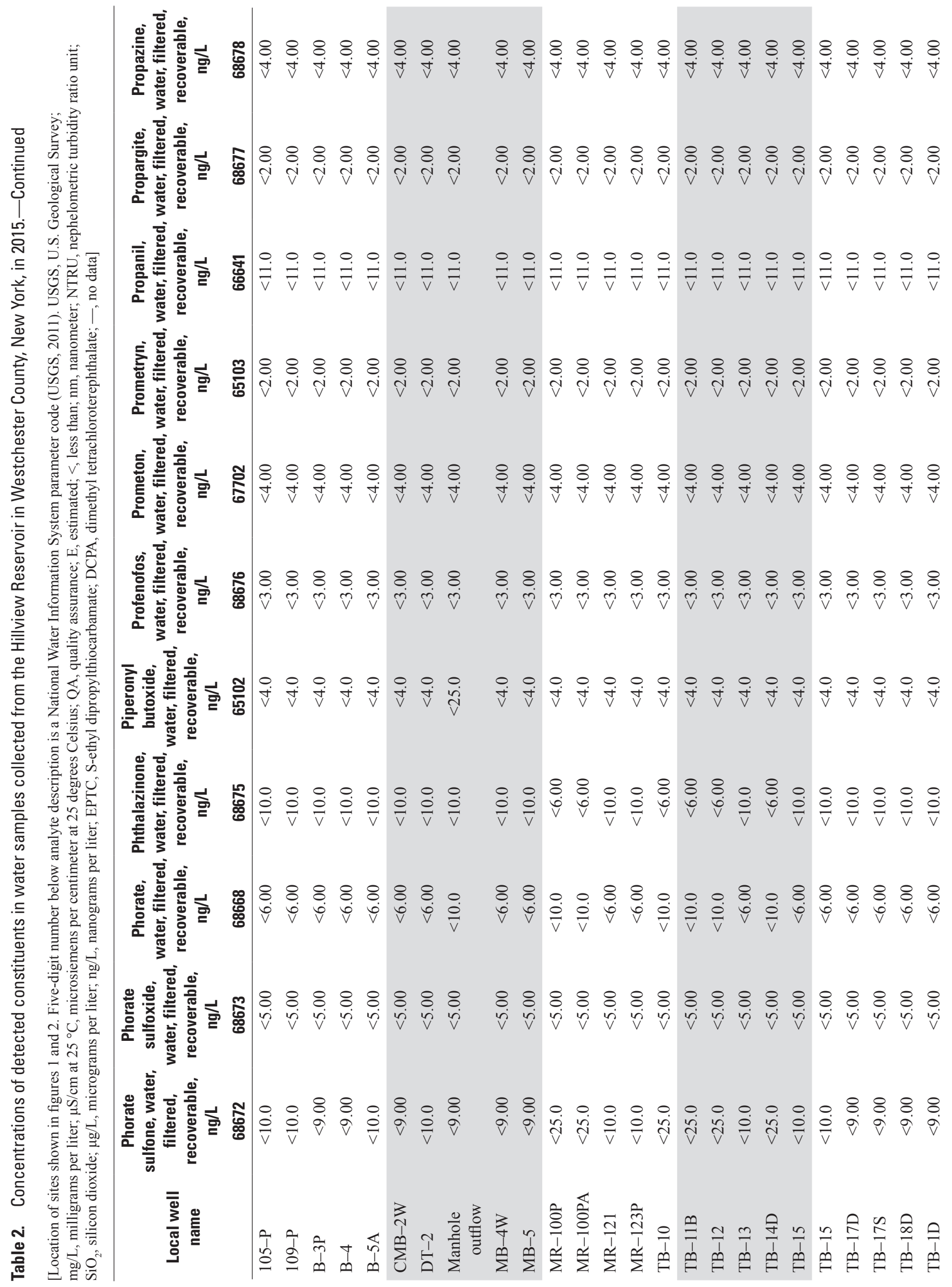




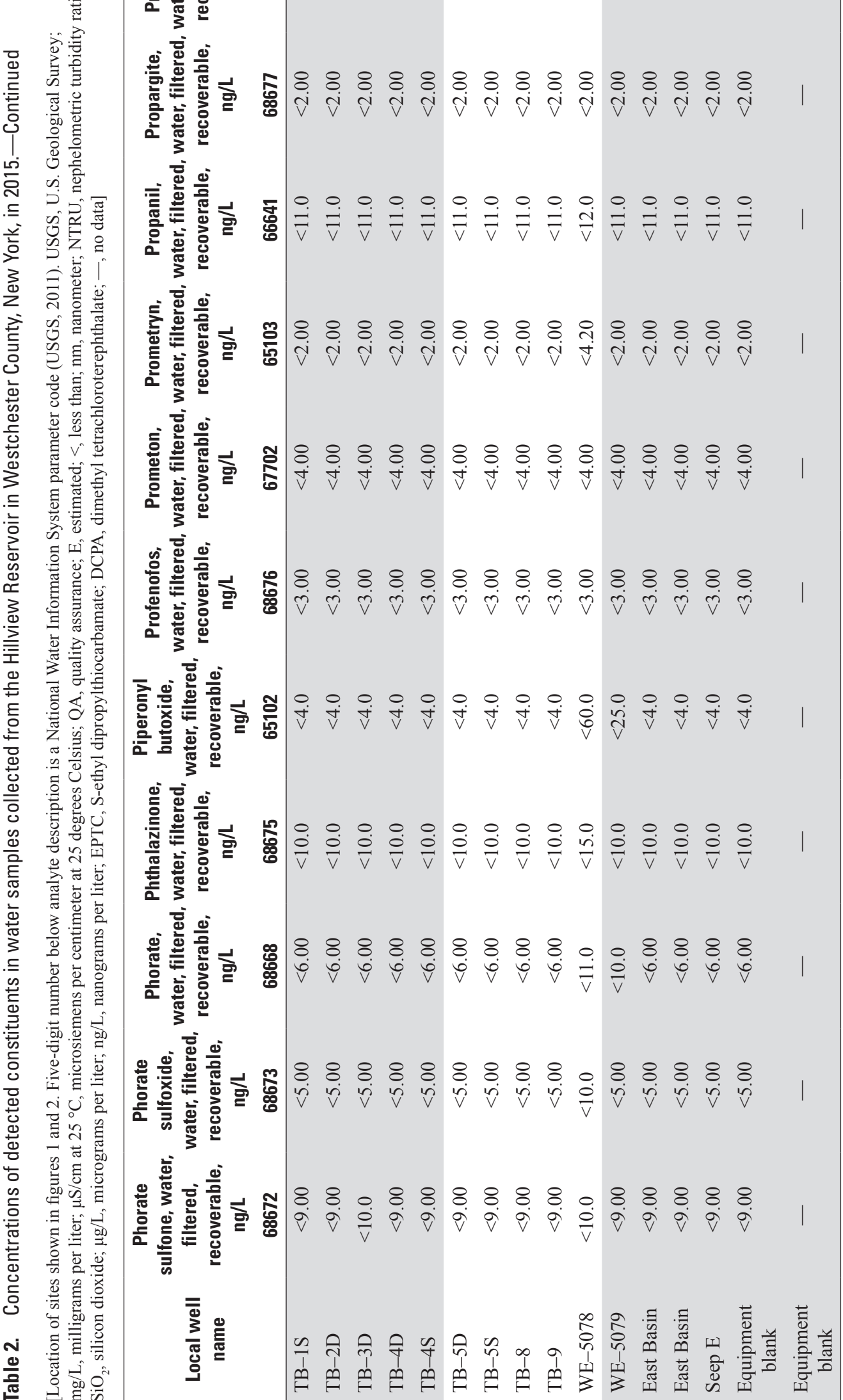




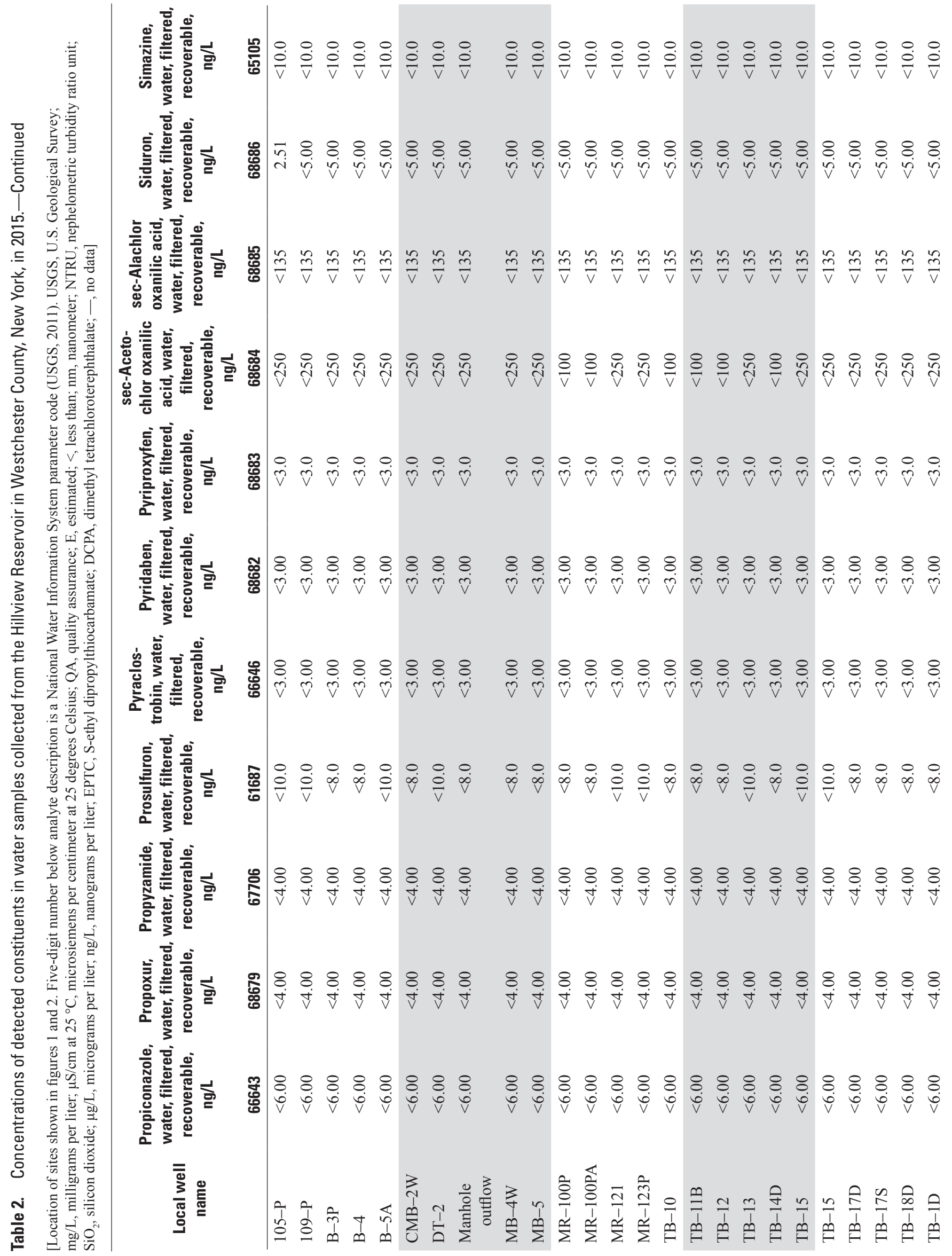




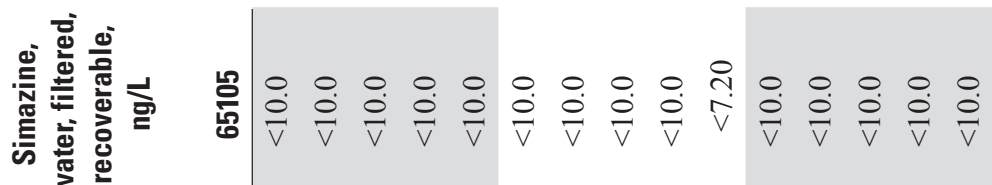

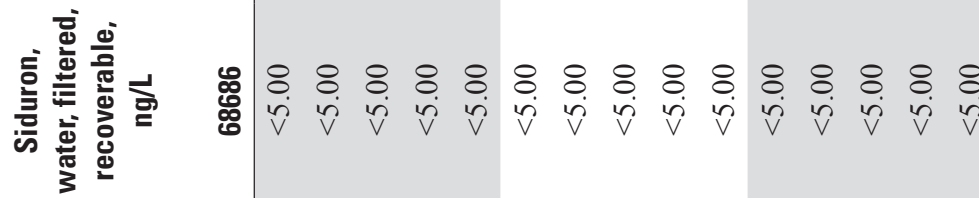

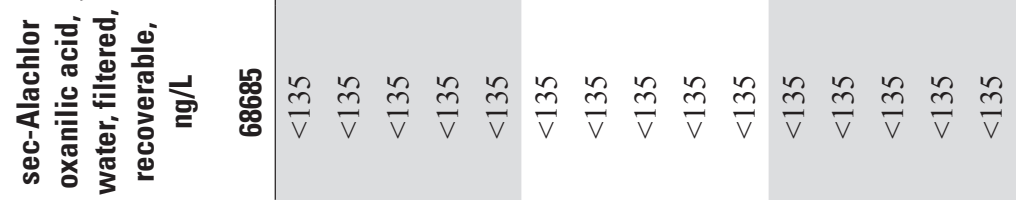

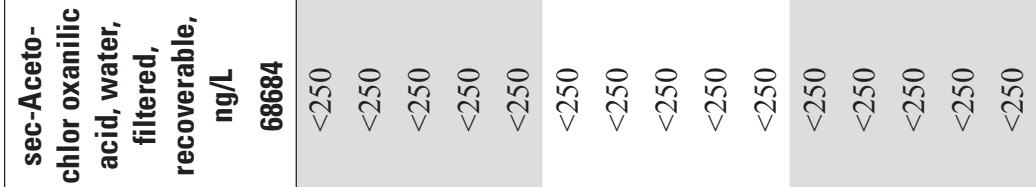

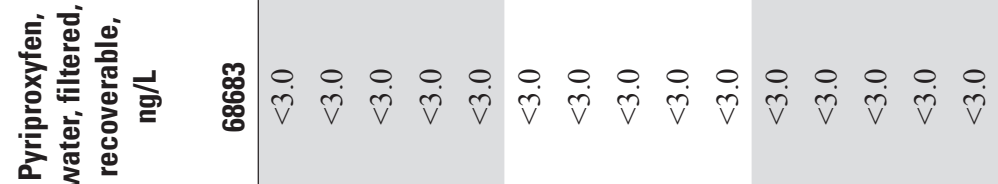

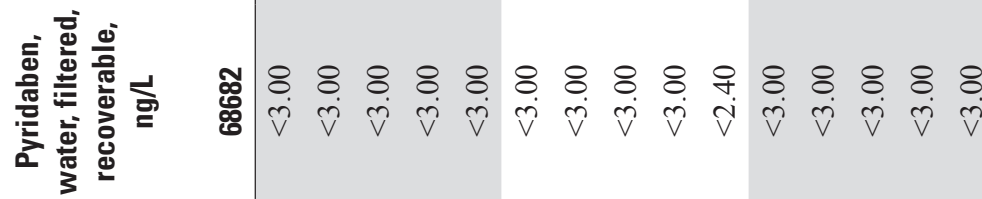

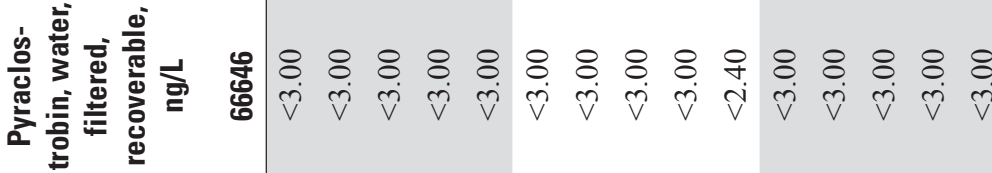

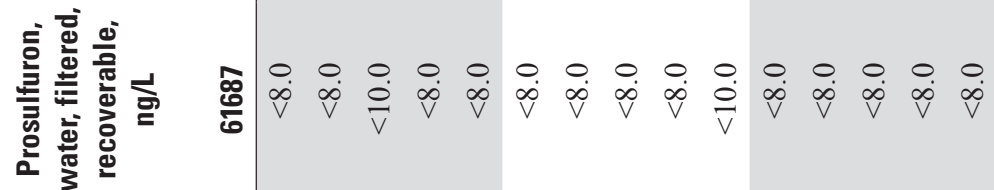
흘

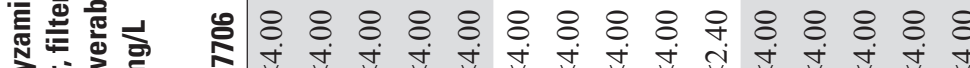

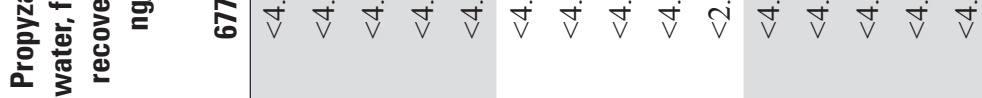

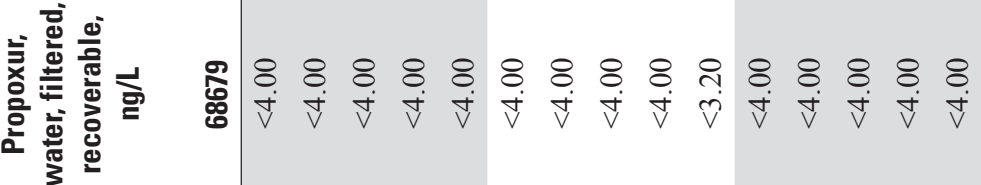

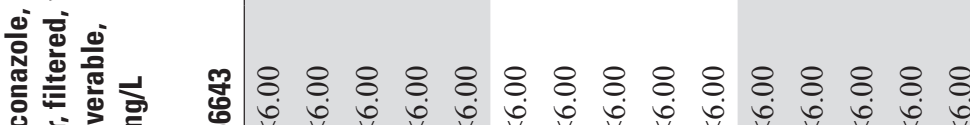

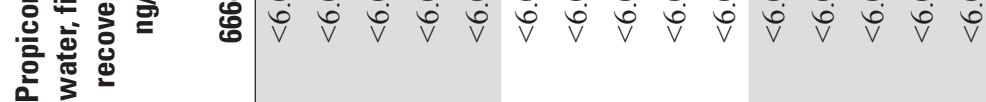




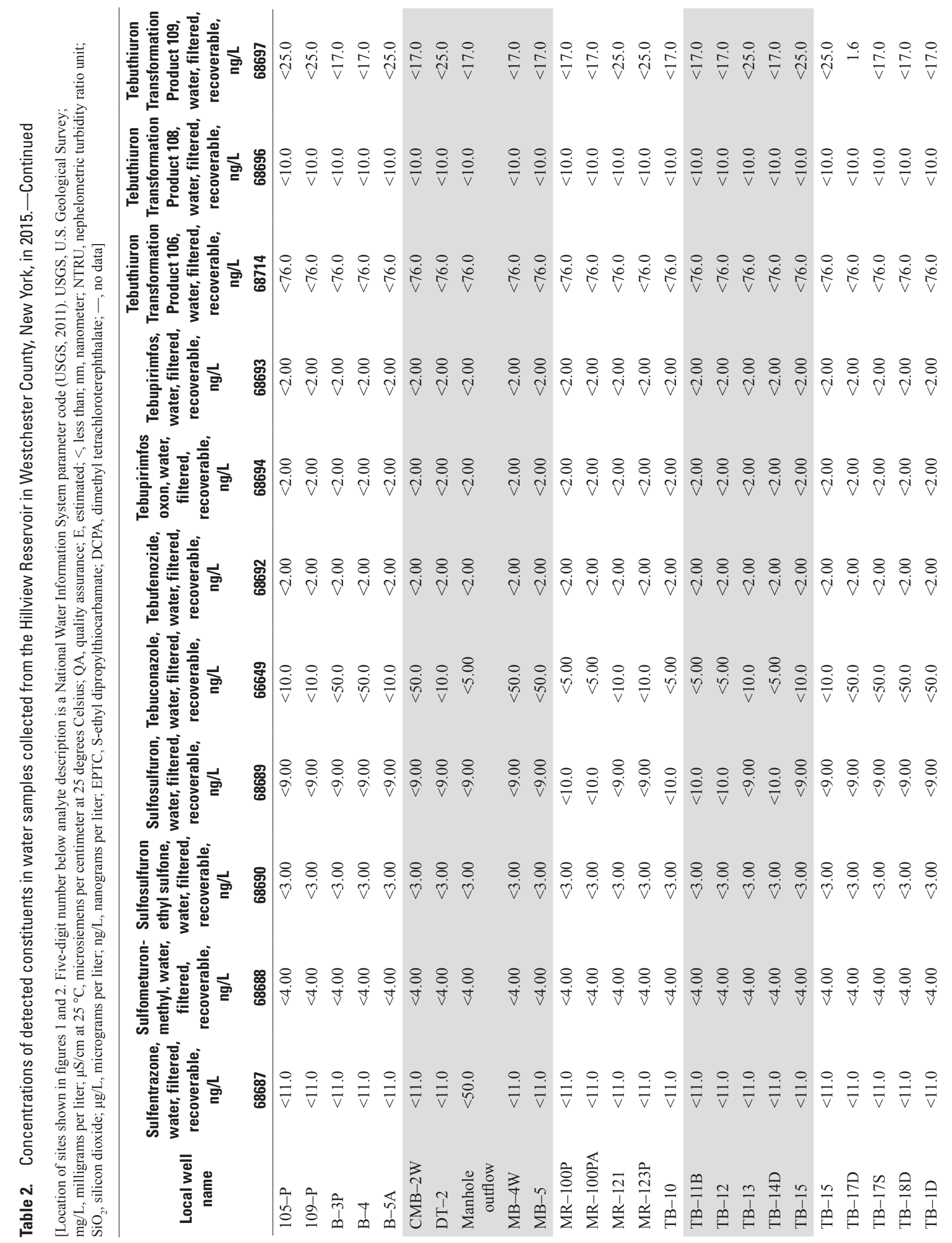




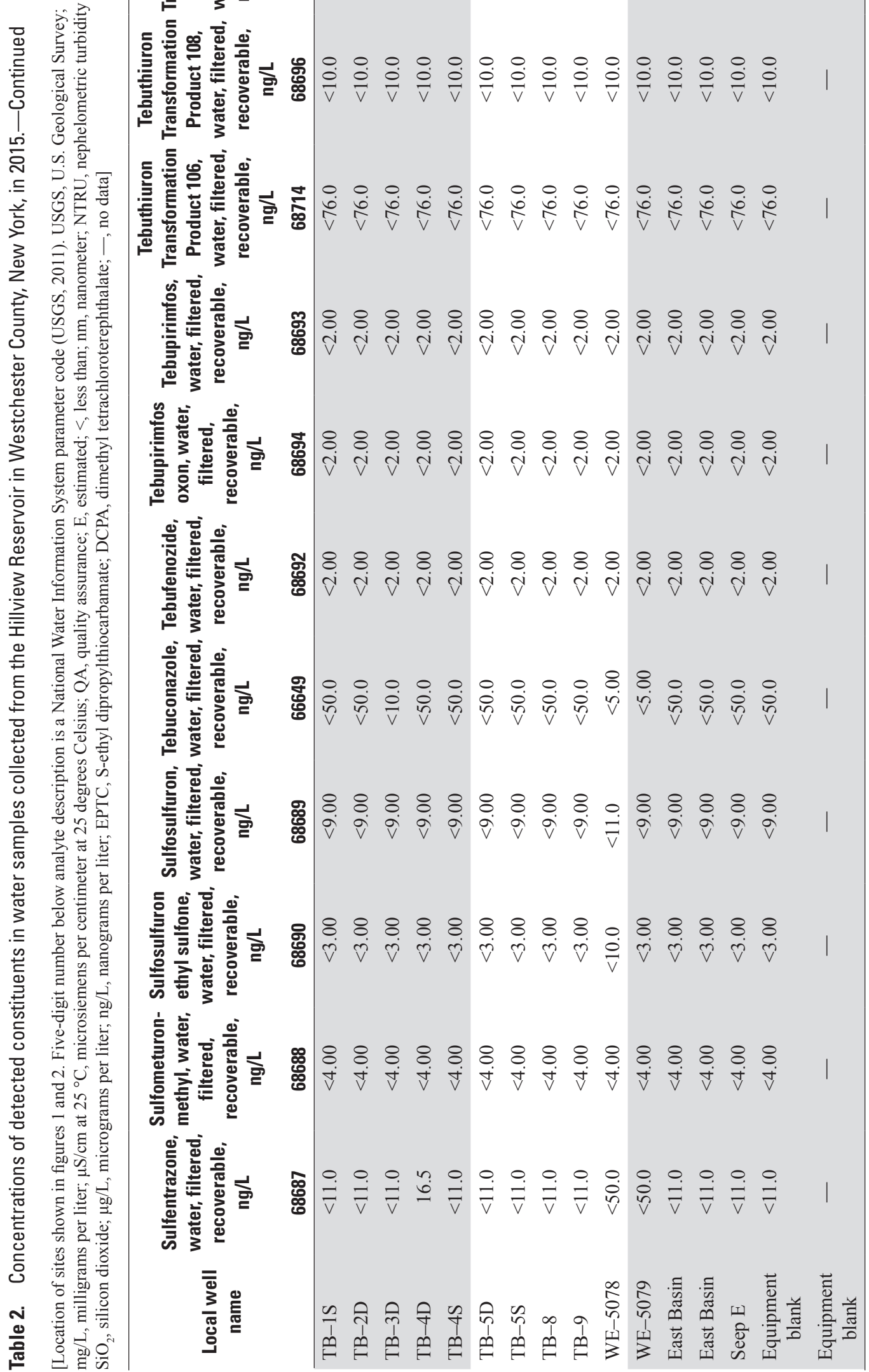




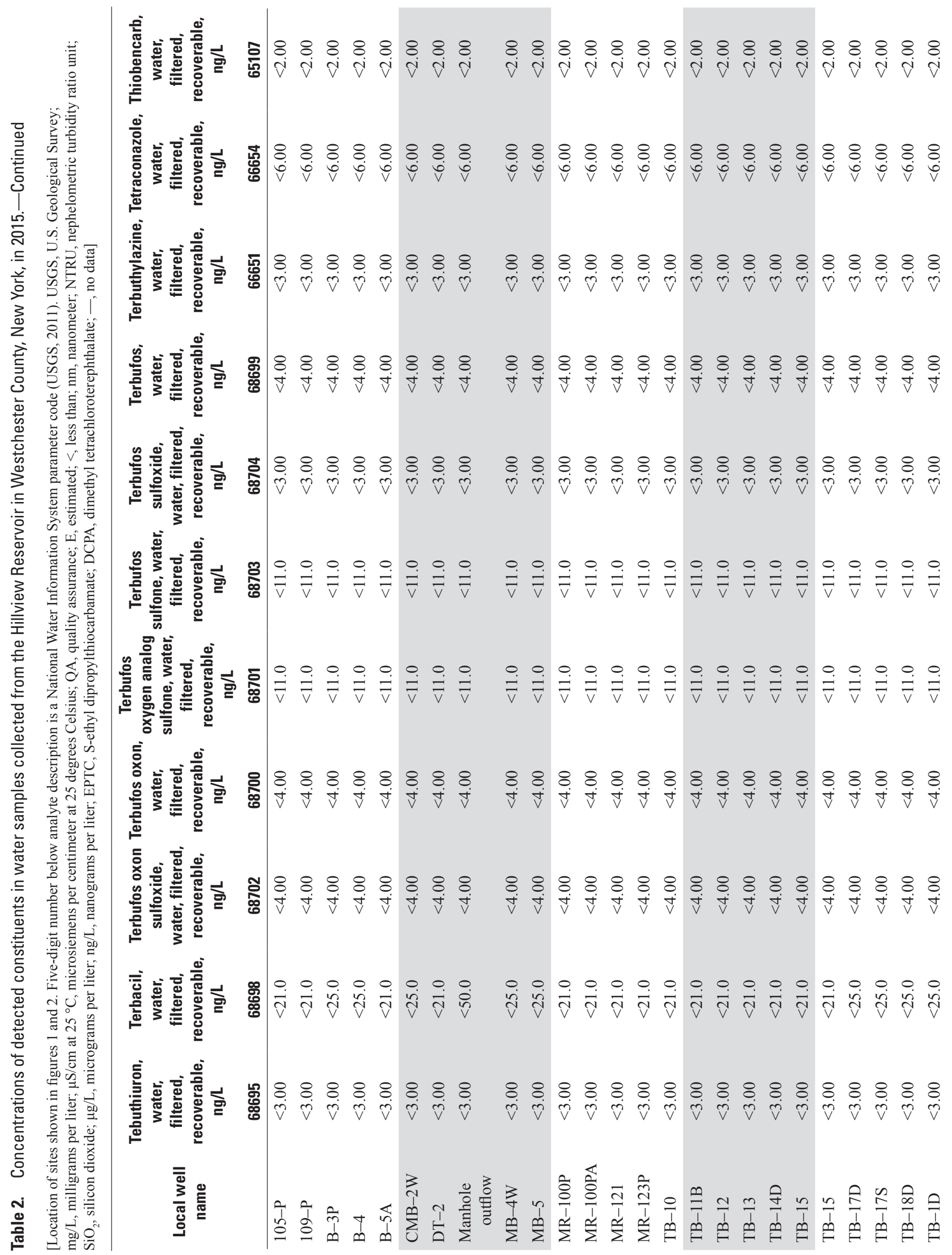




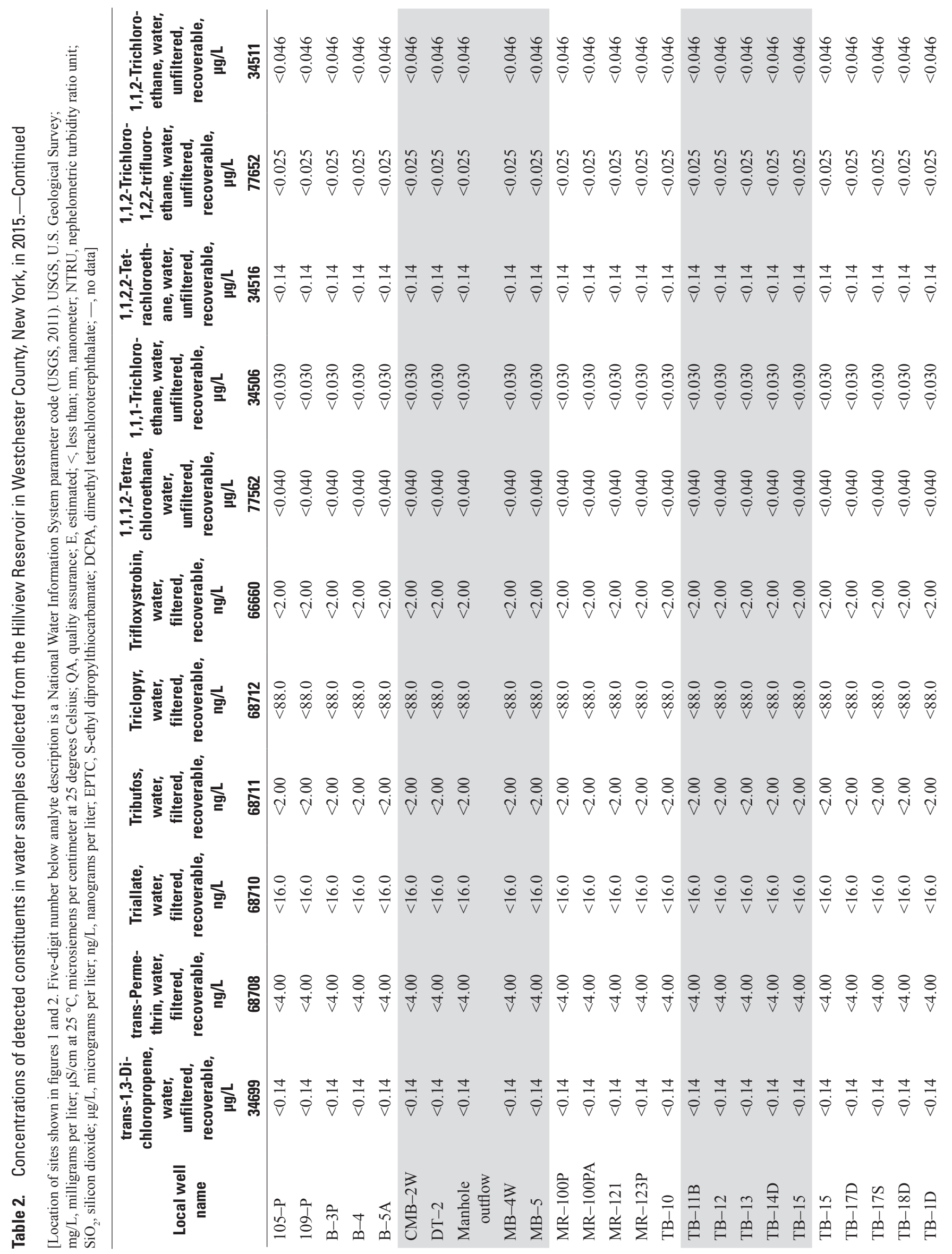




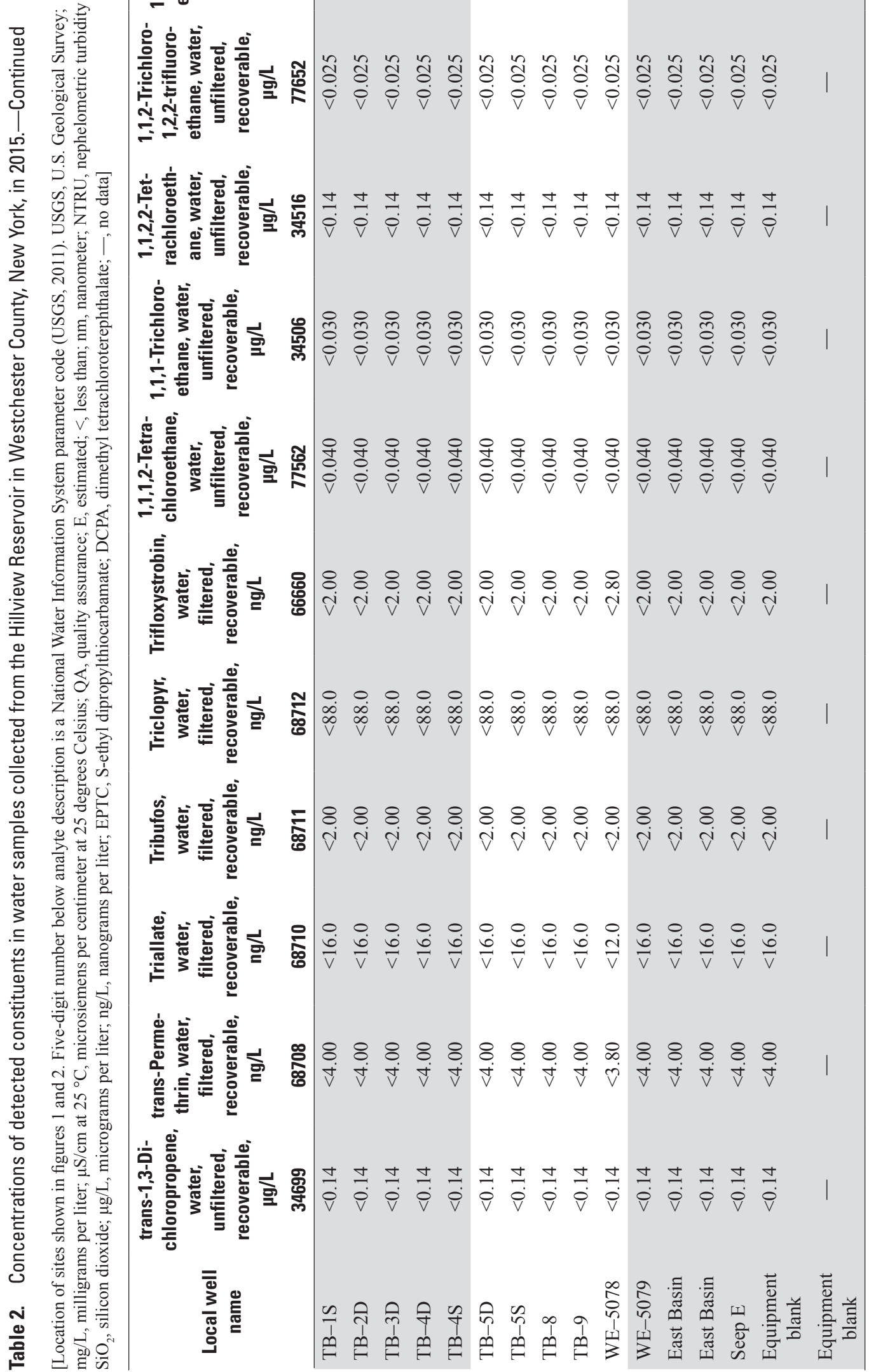




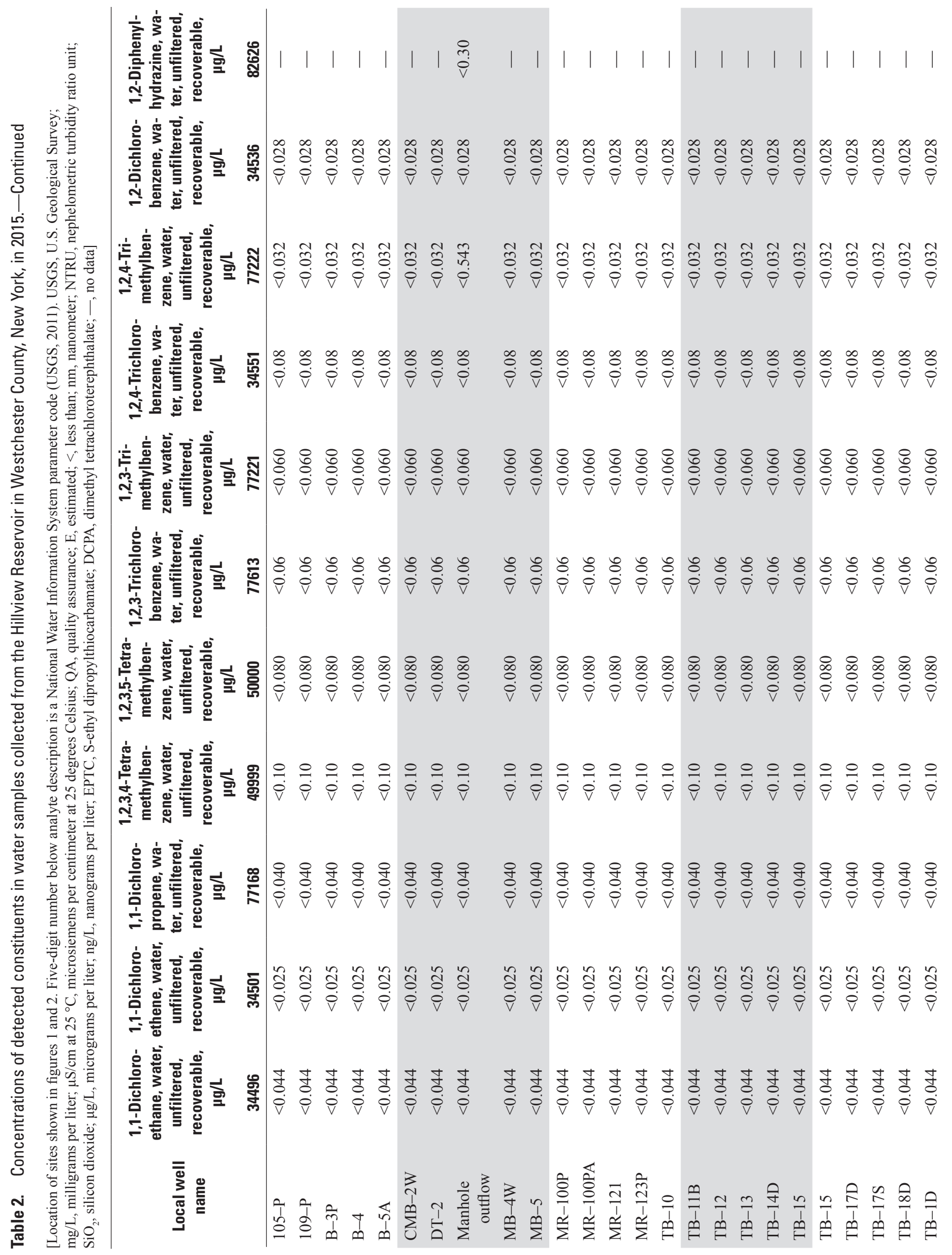




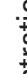

홍

ปั के

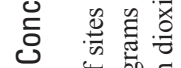

ง

竞

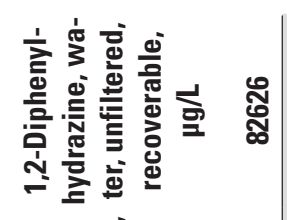

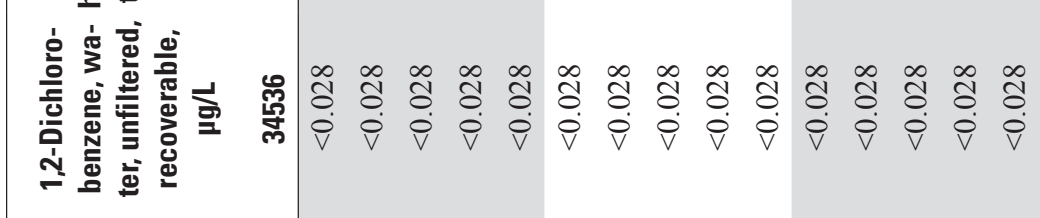

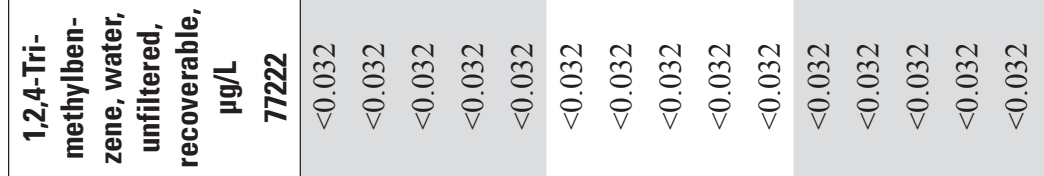

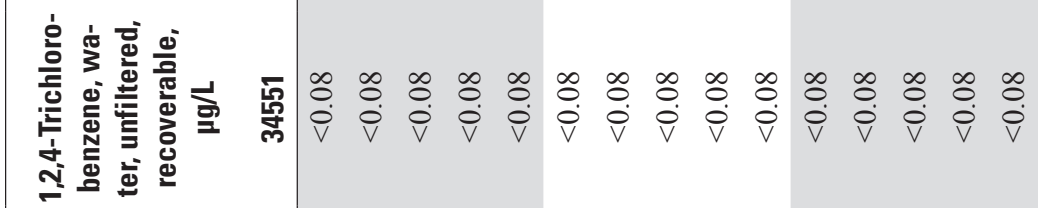

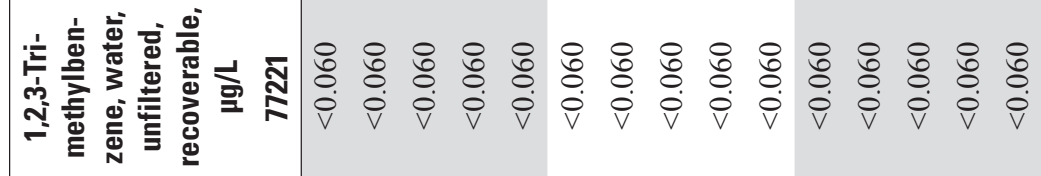

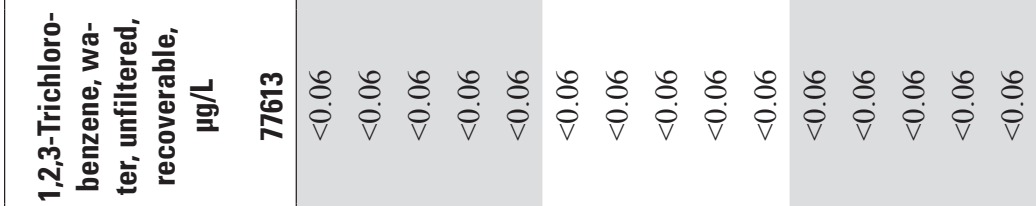

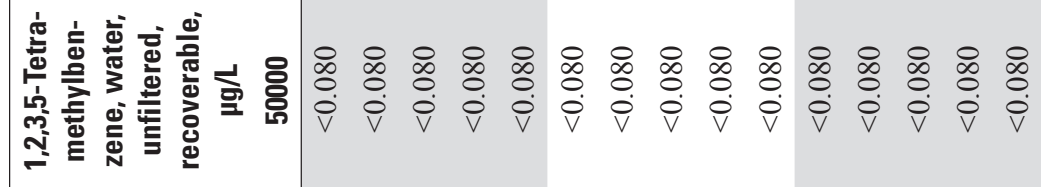

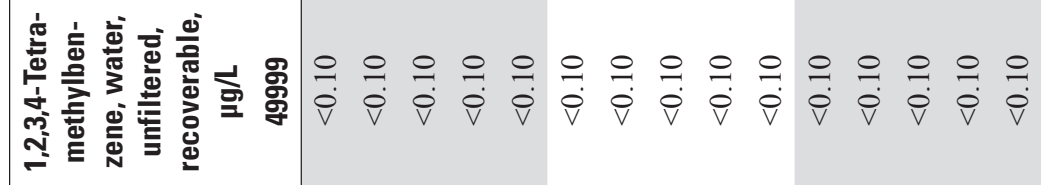

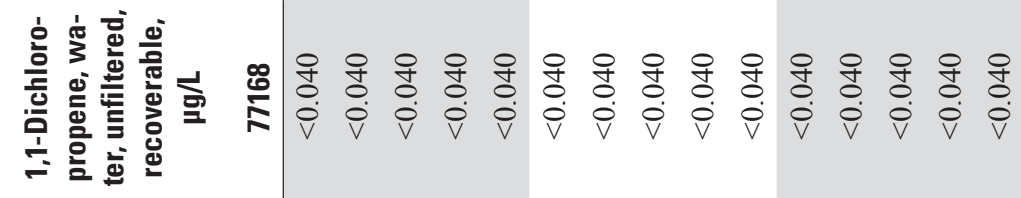

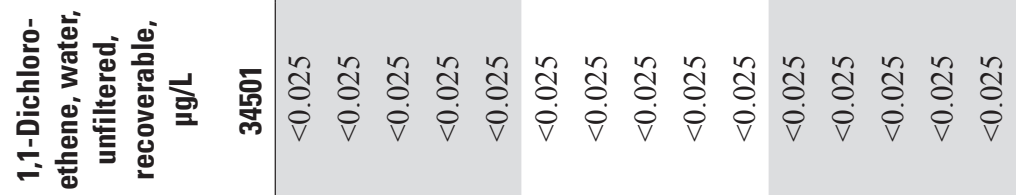

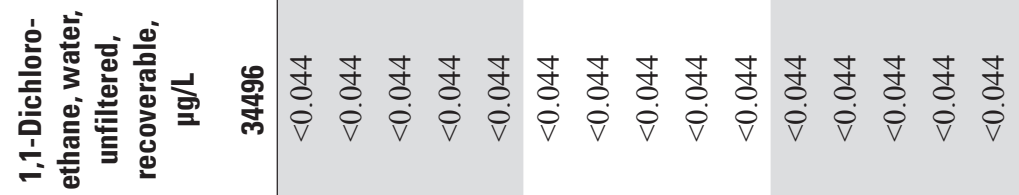
离

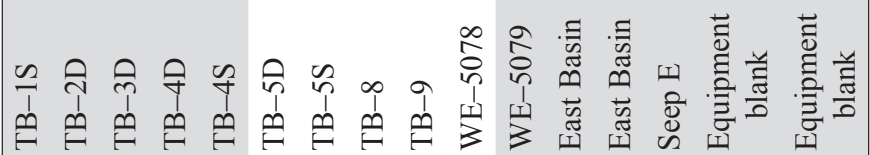




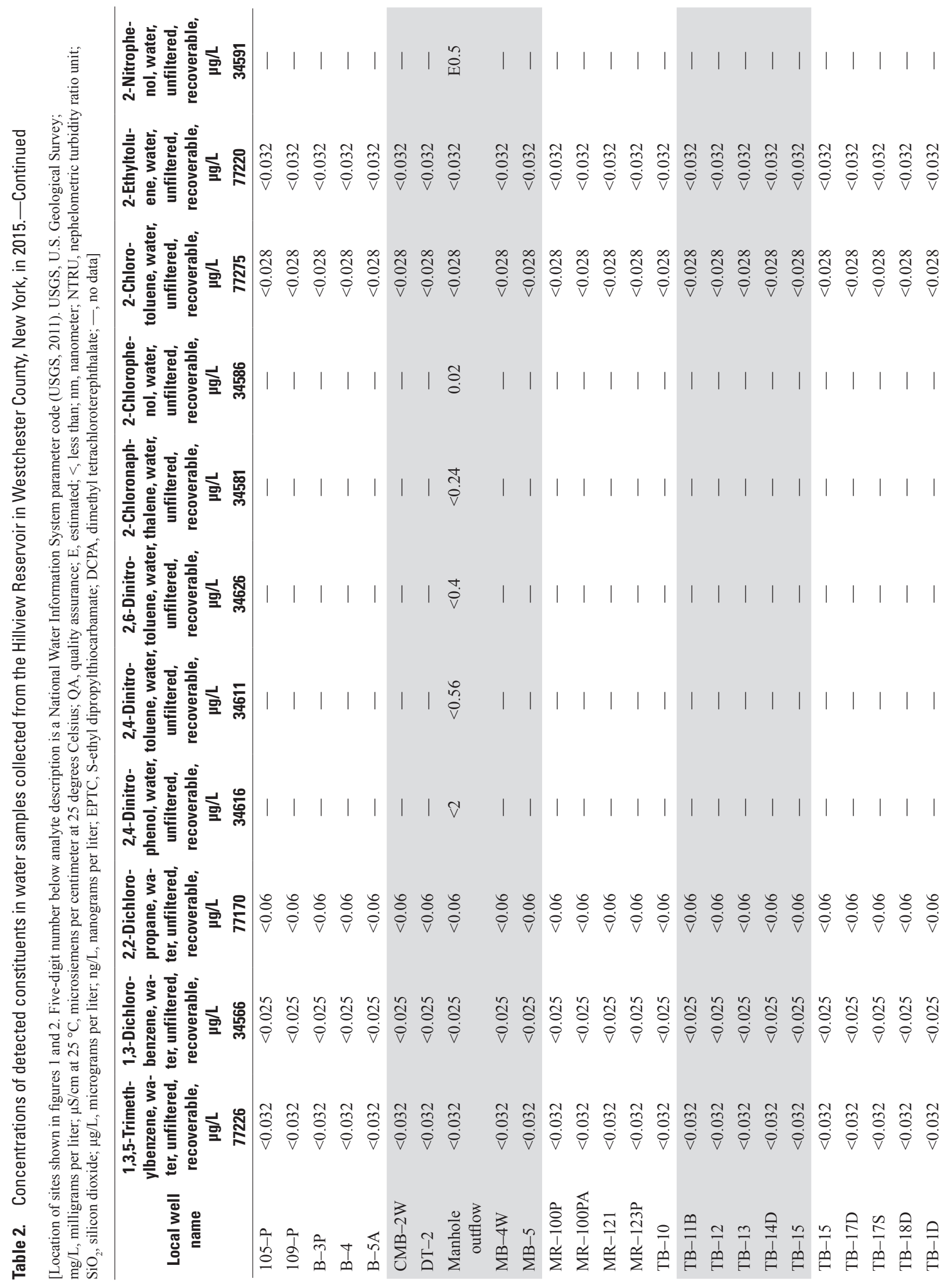




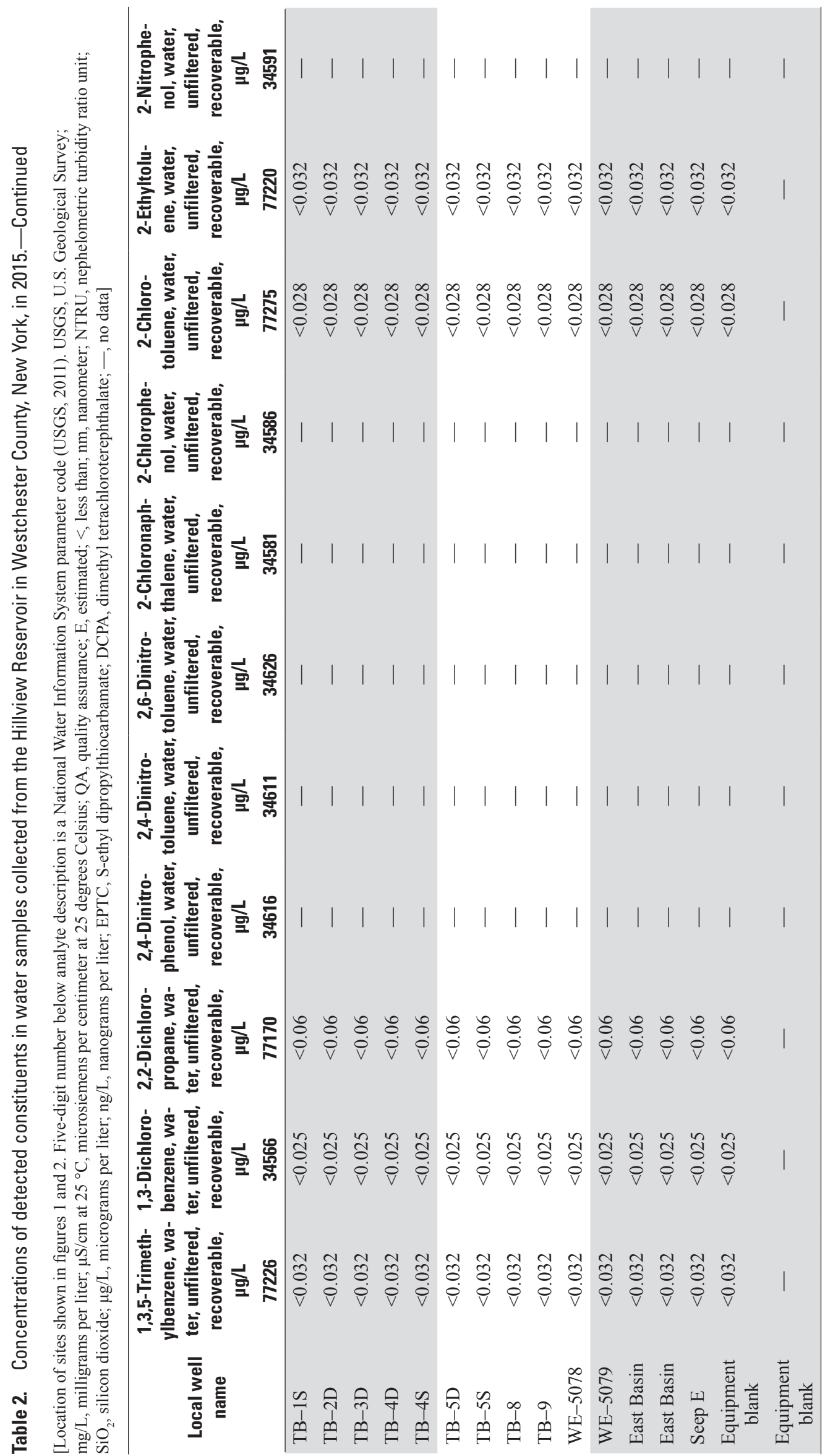




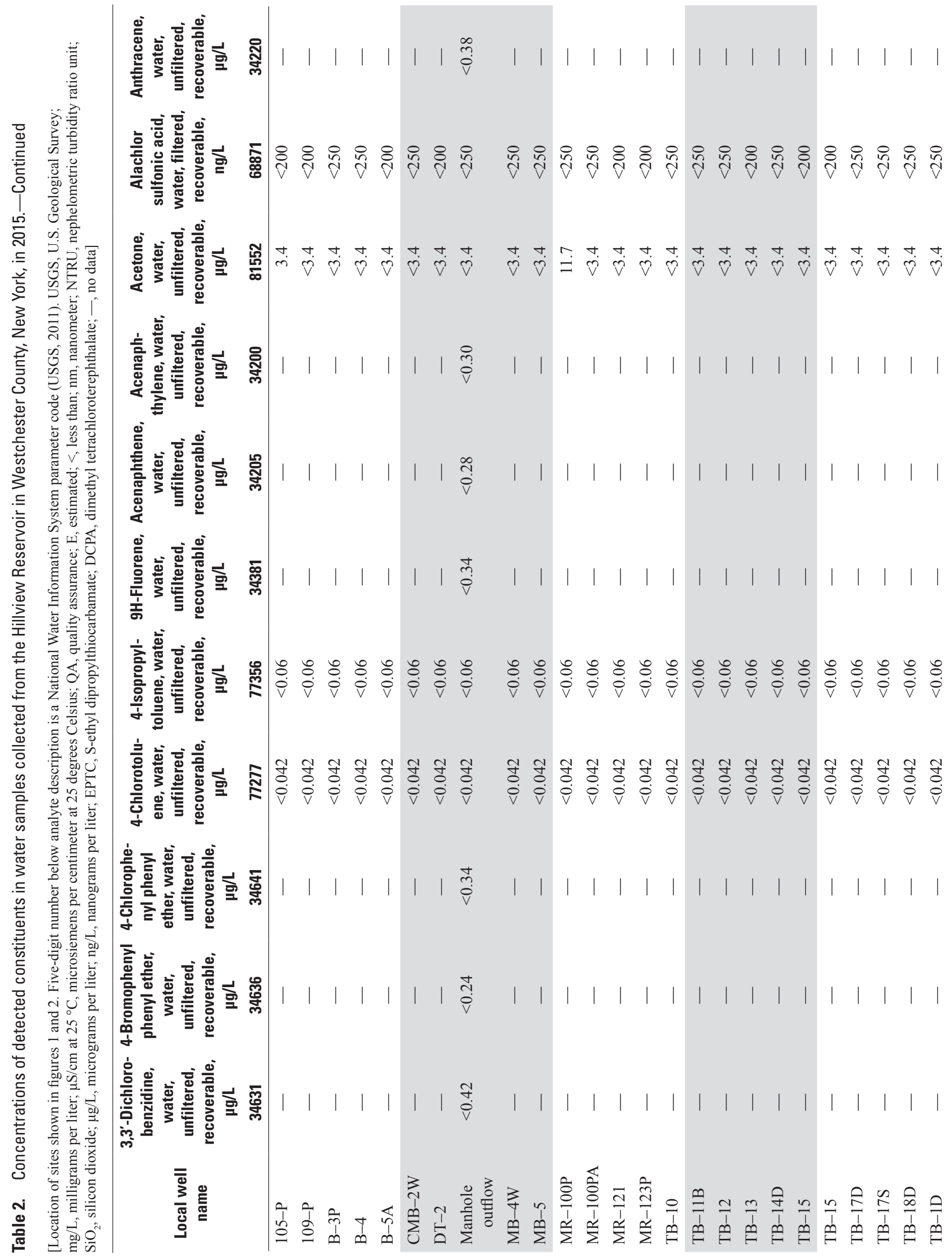


灾司

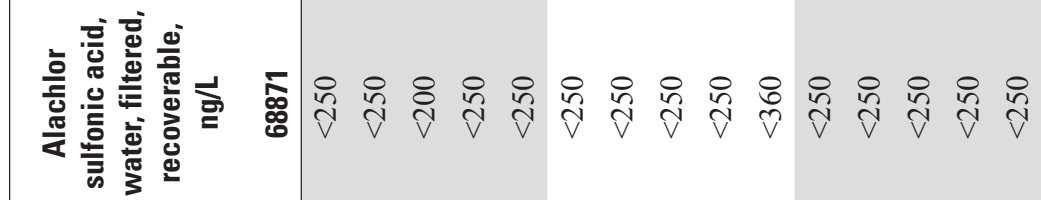

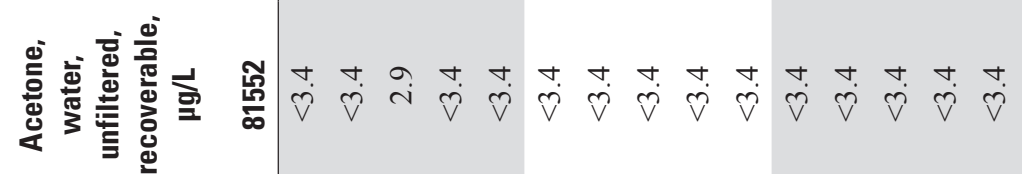

命

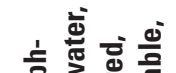

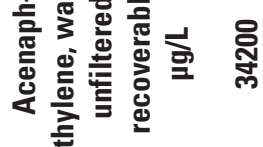

음

혼

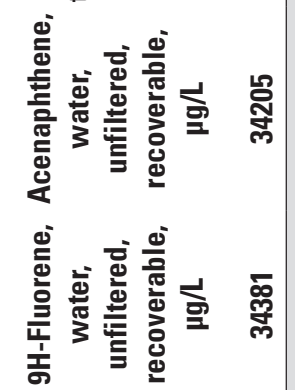

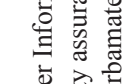

政

등

क्र

के मी

咩

言离㐫

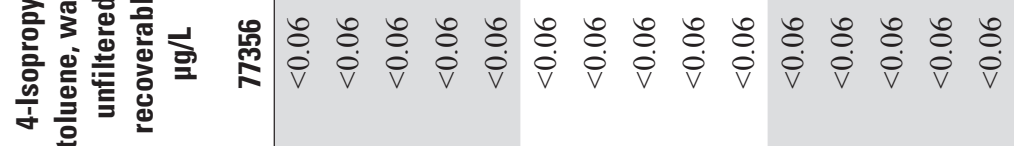

임 $\frac{\pi}{0}$

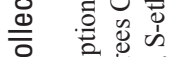

\&

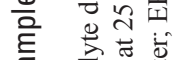

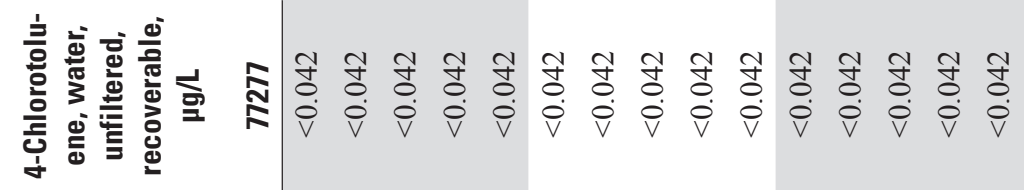

屯

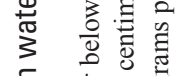

들

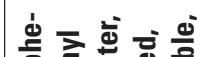

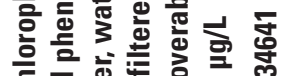

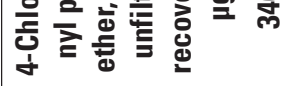

E

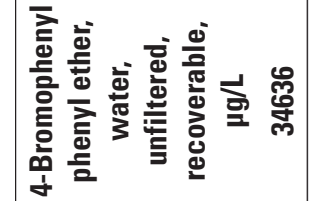

zo

\&.

诖

ज त

क元

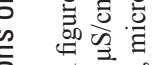

은

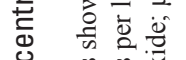

ठั

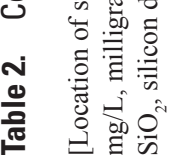

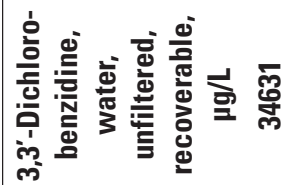

焉

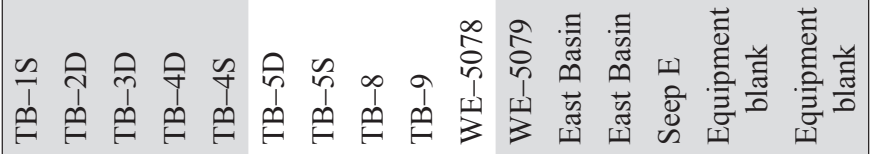




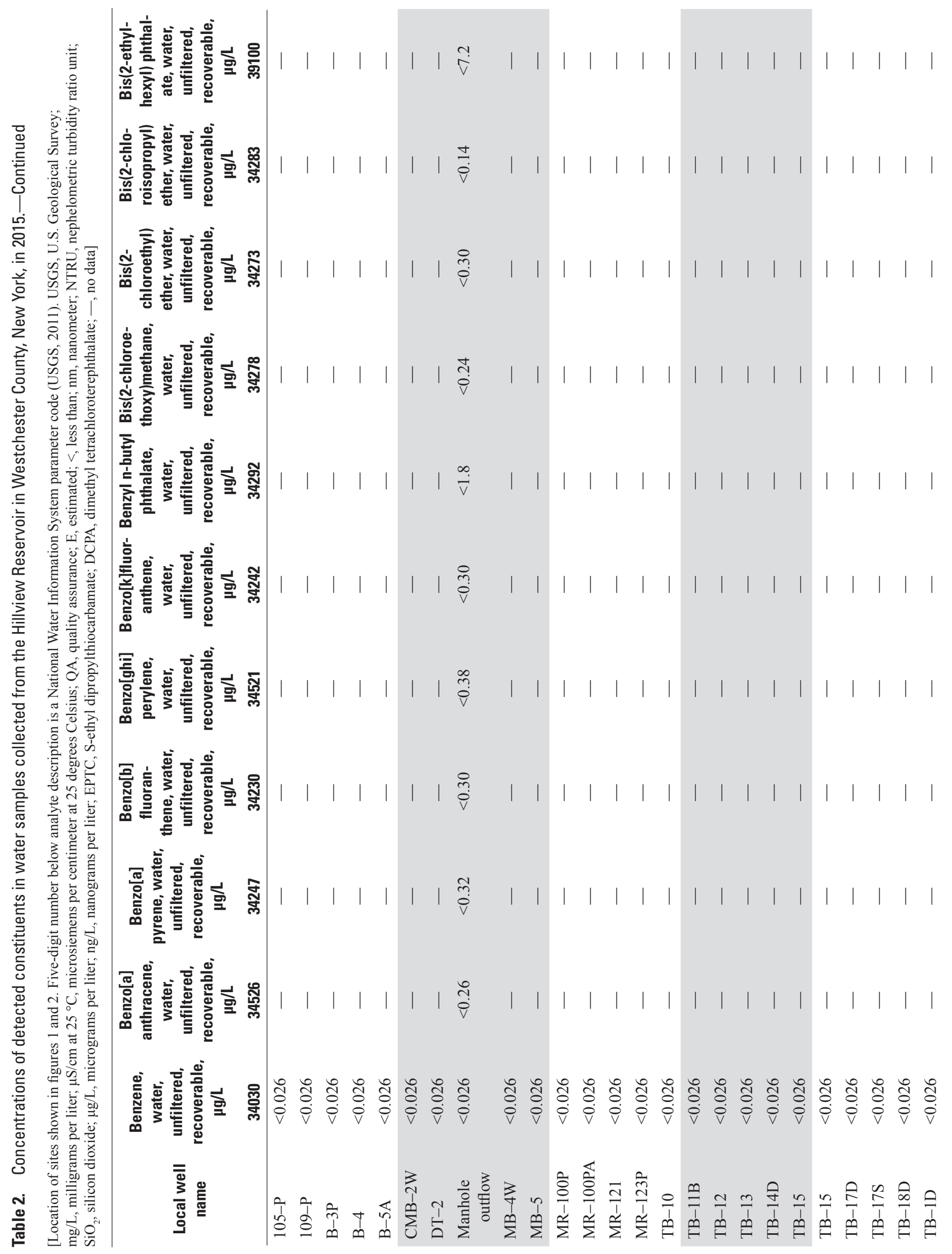




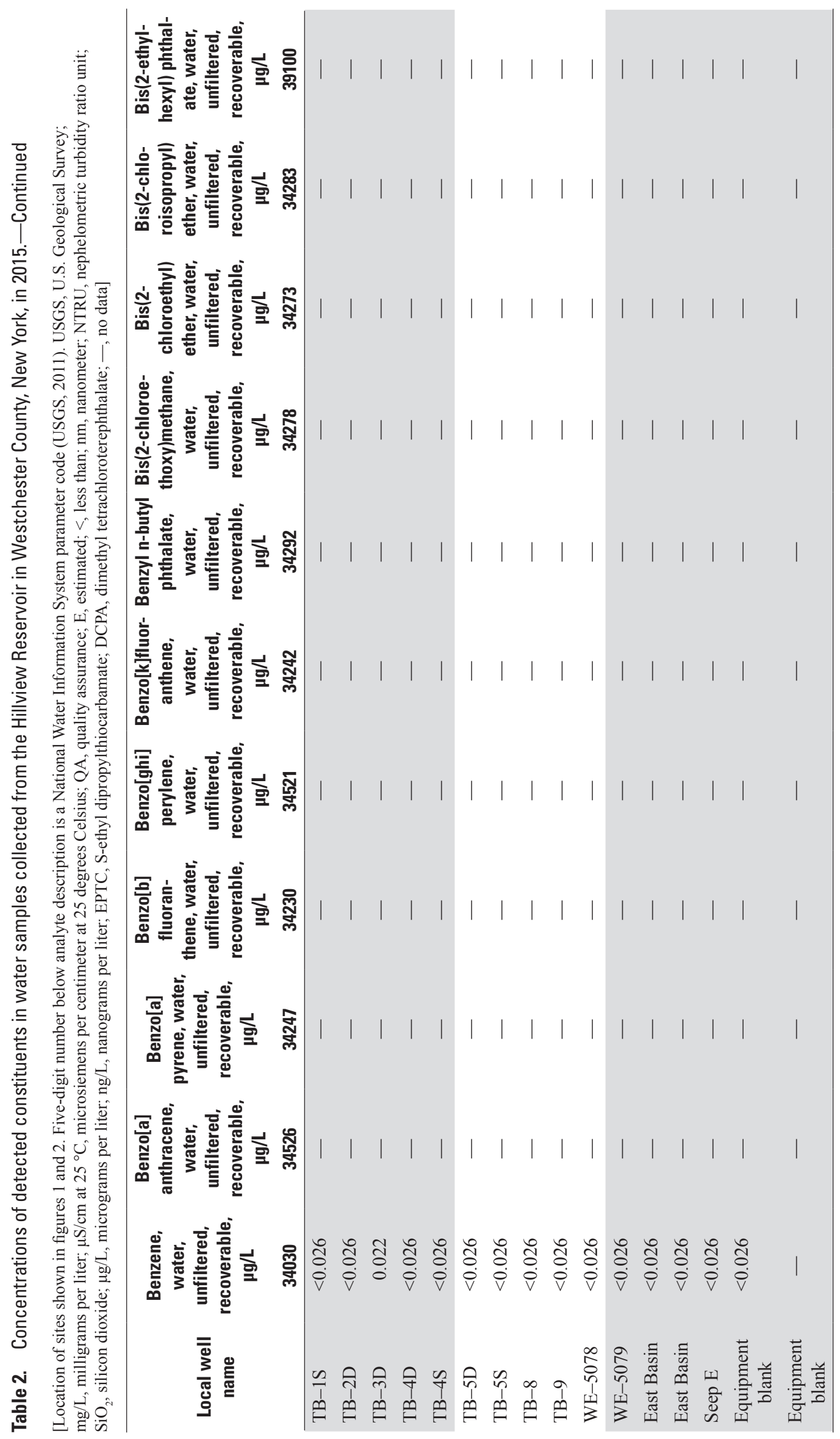




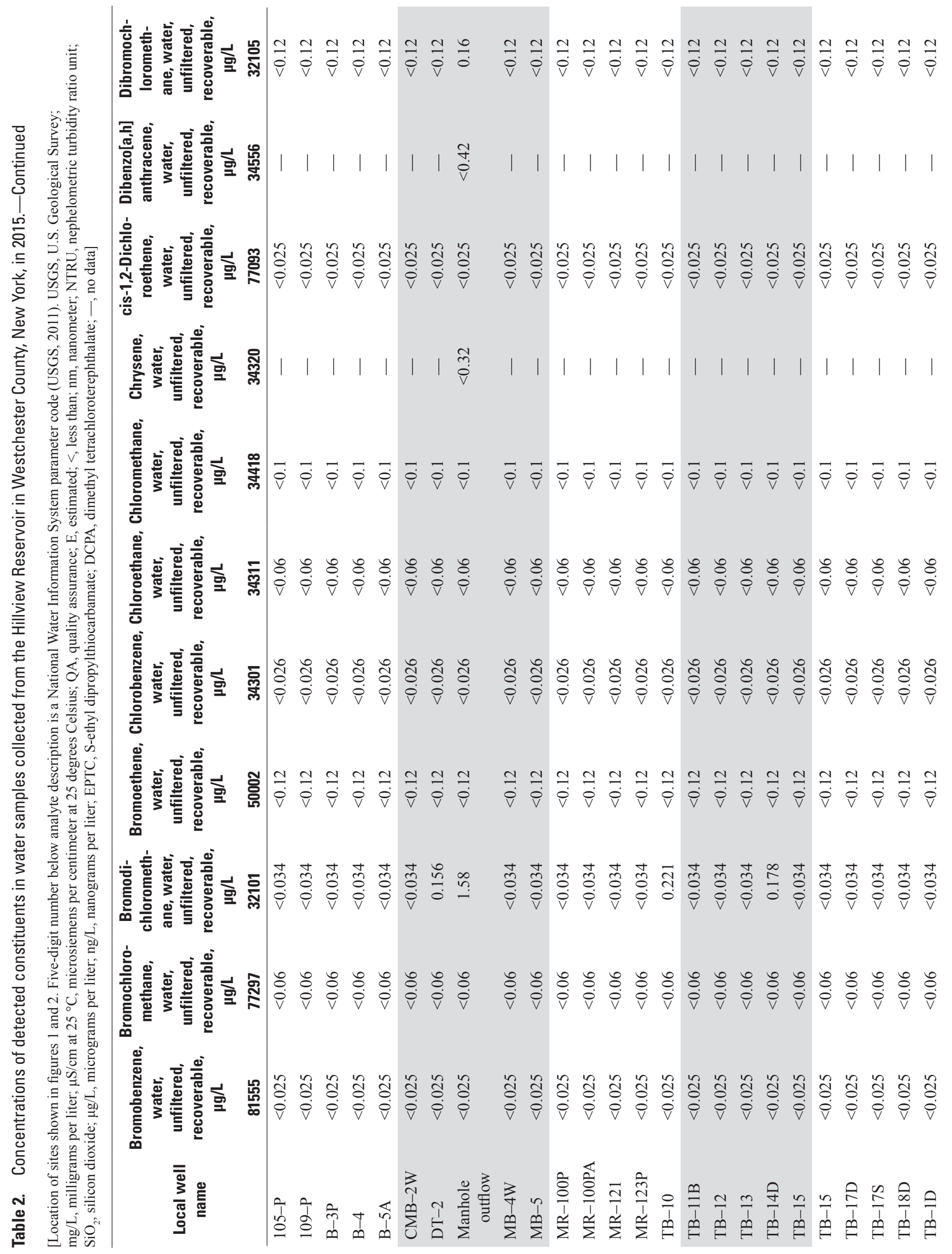




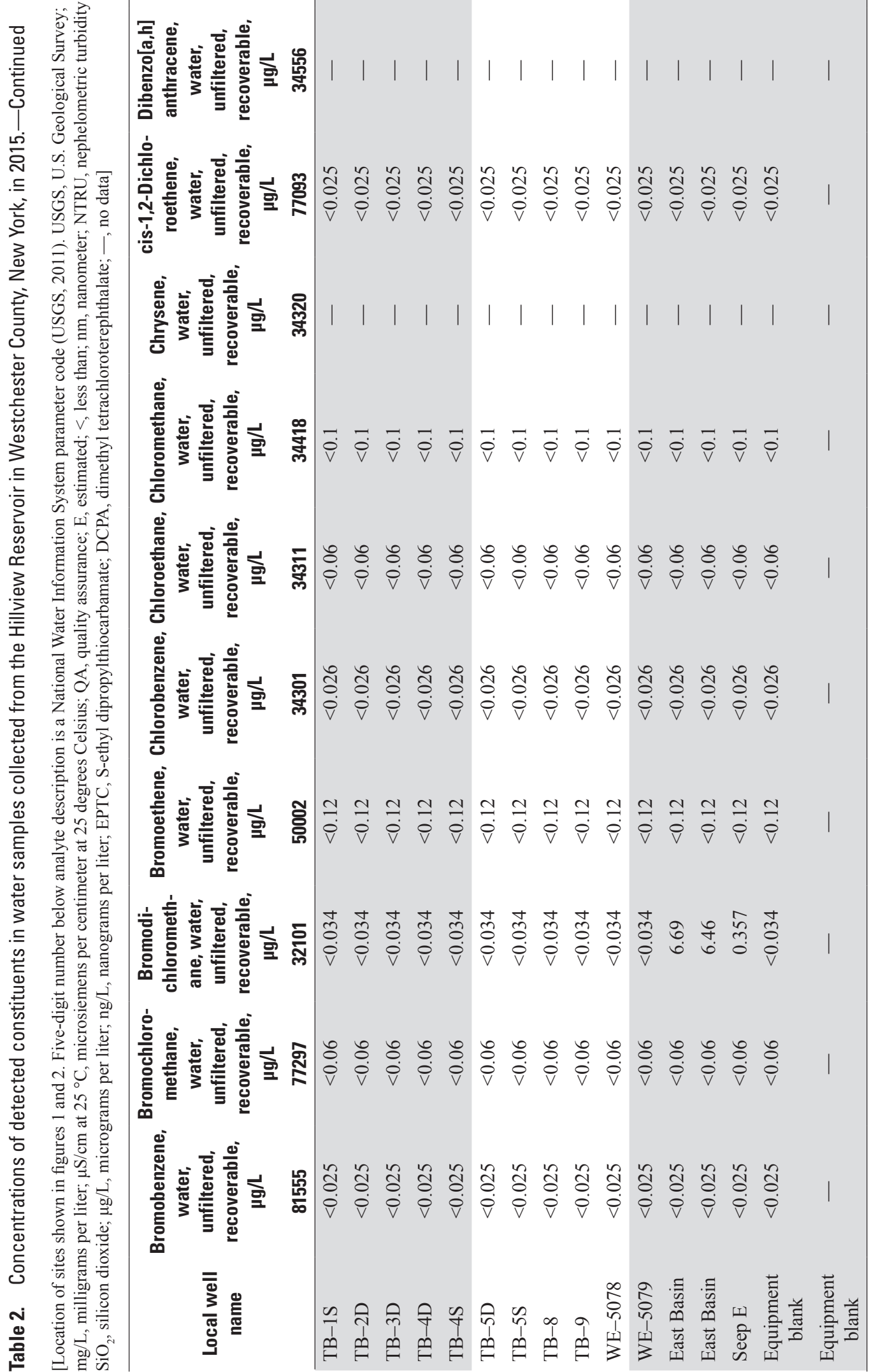




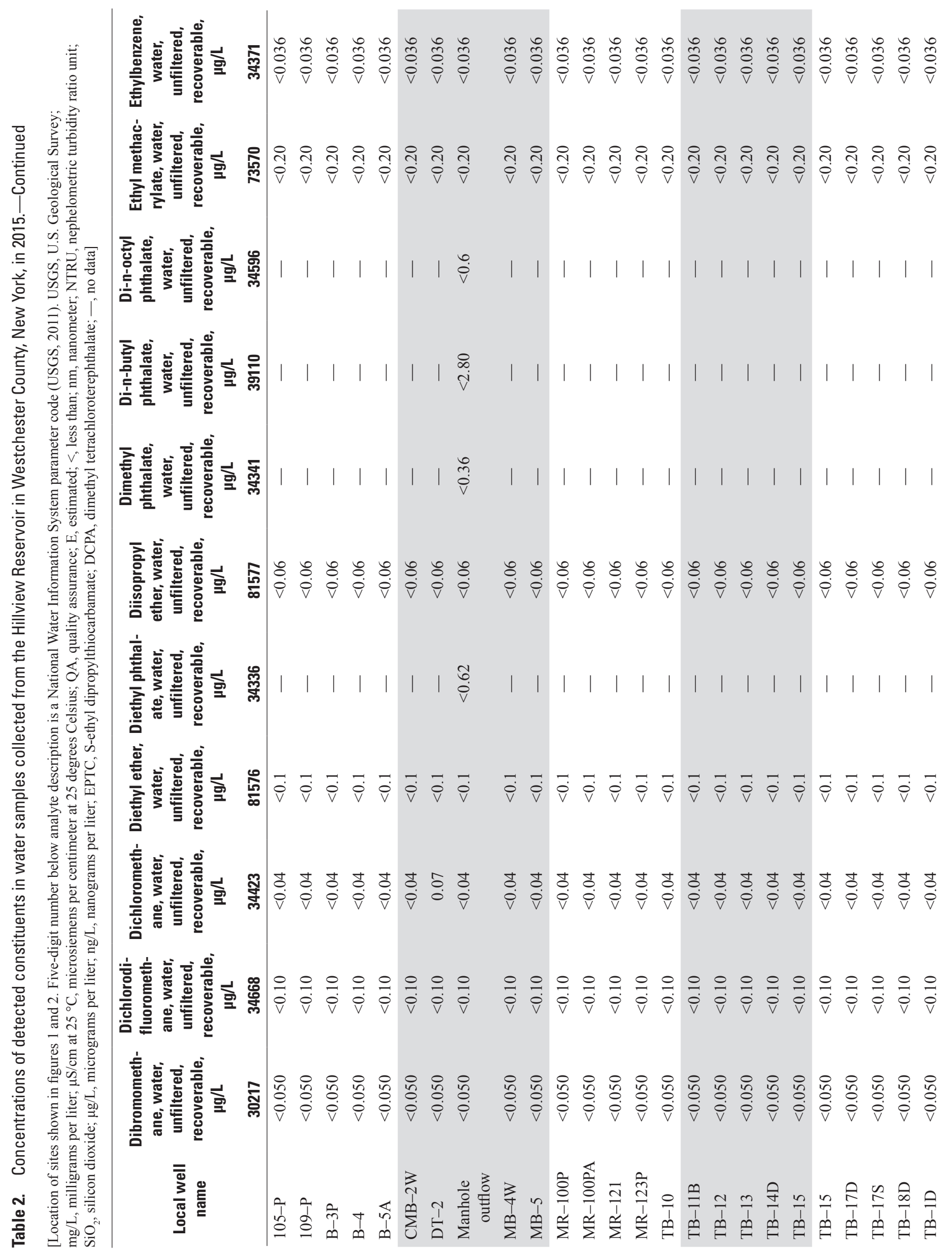




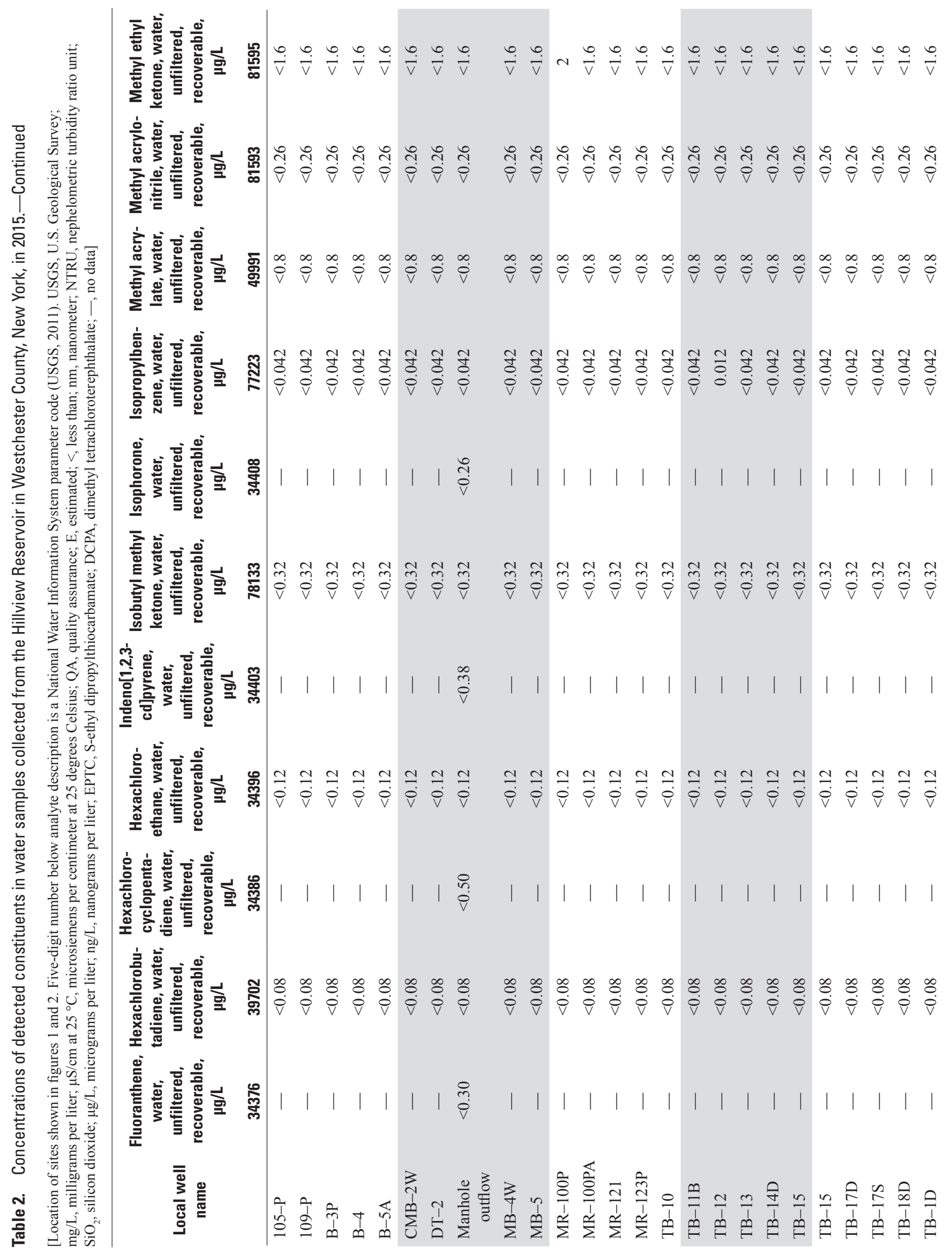




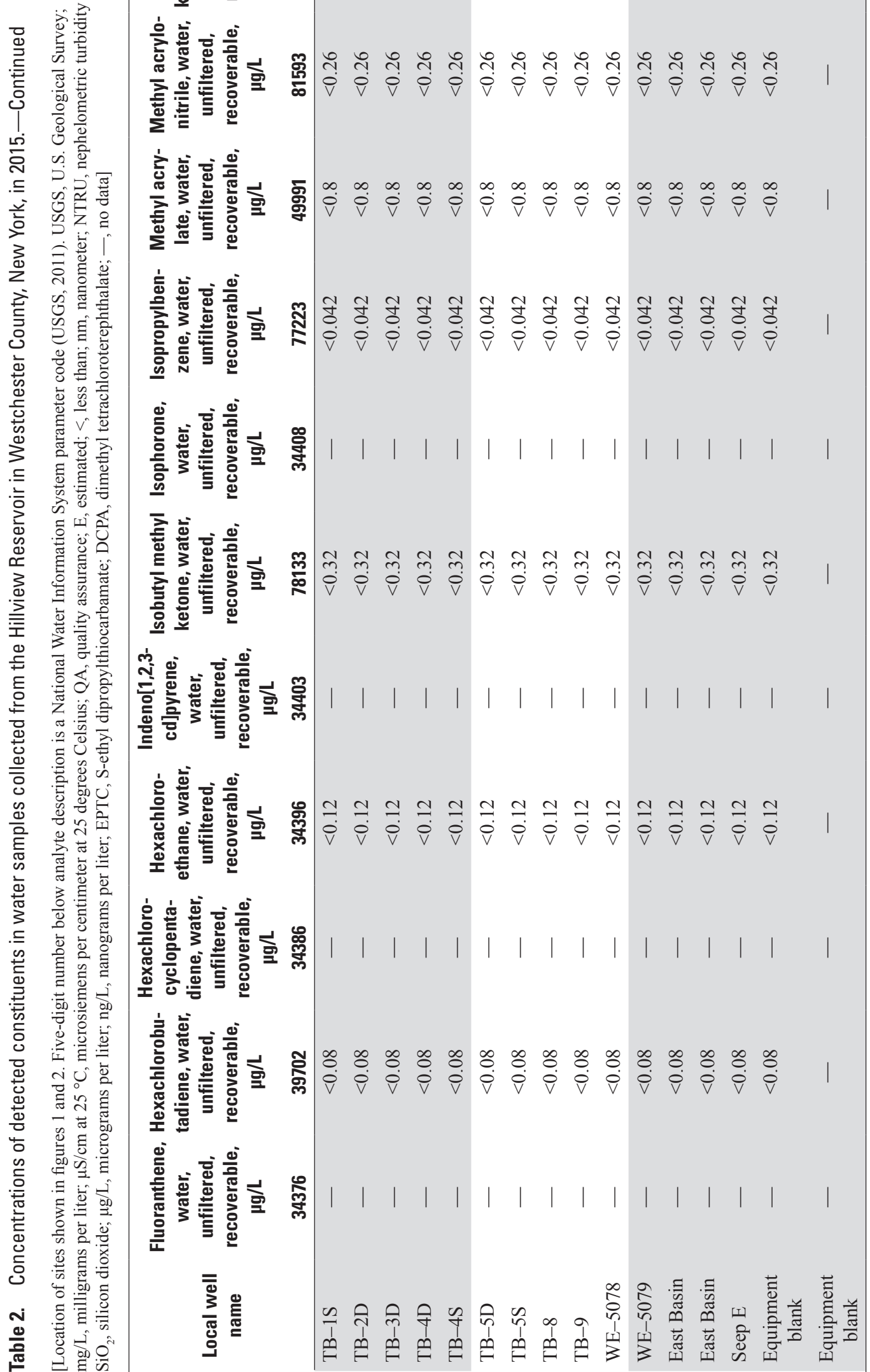




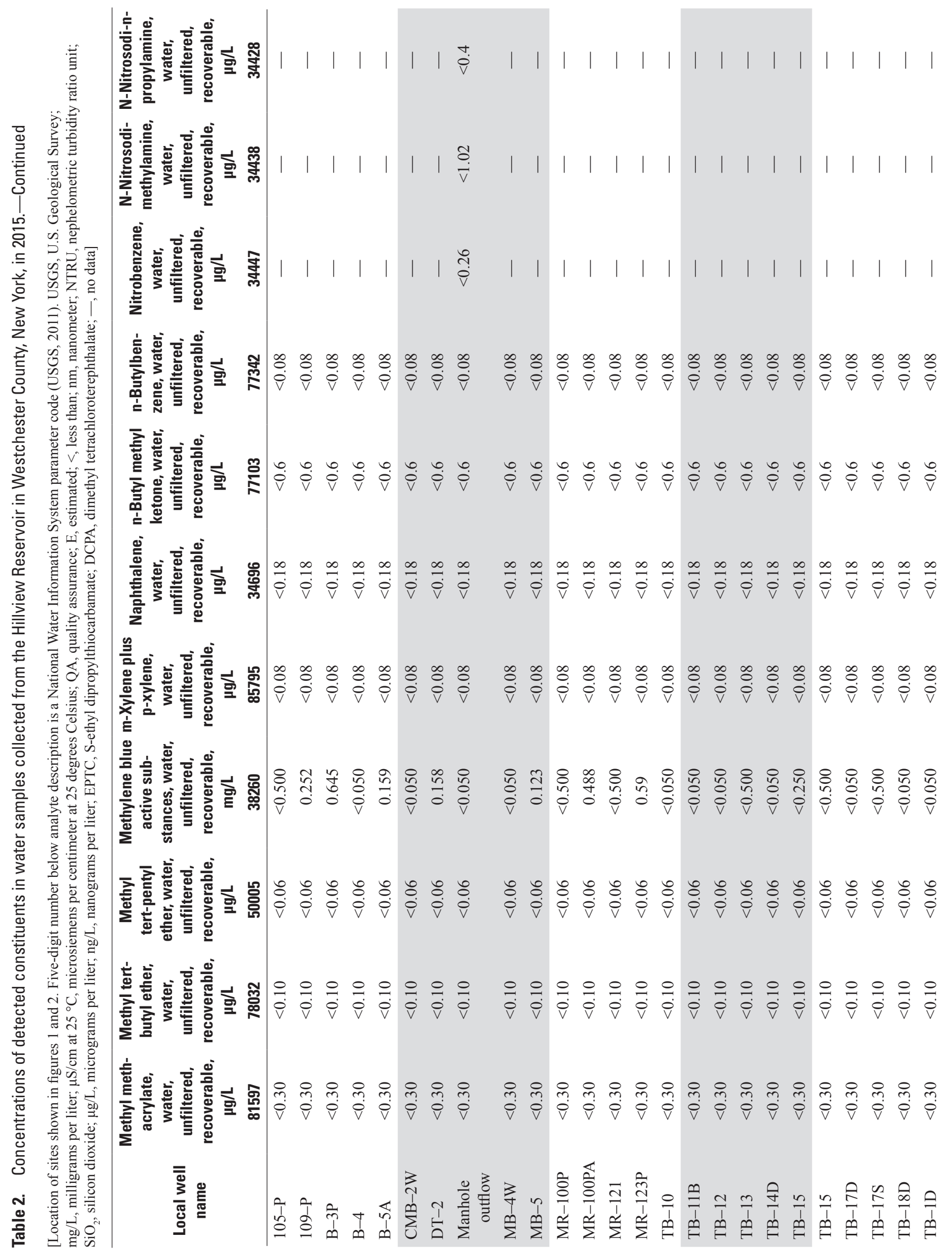


害

कृ
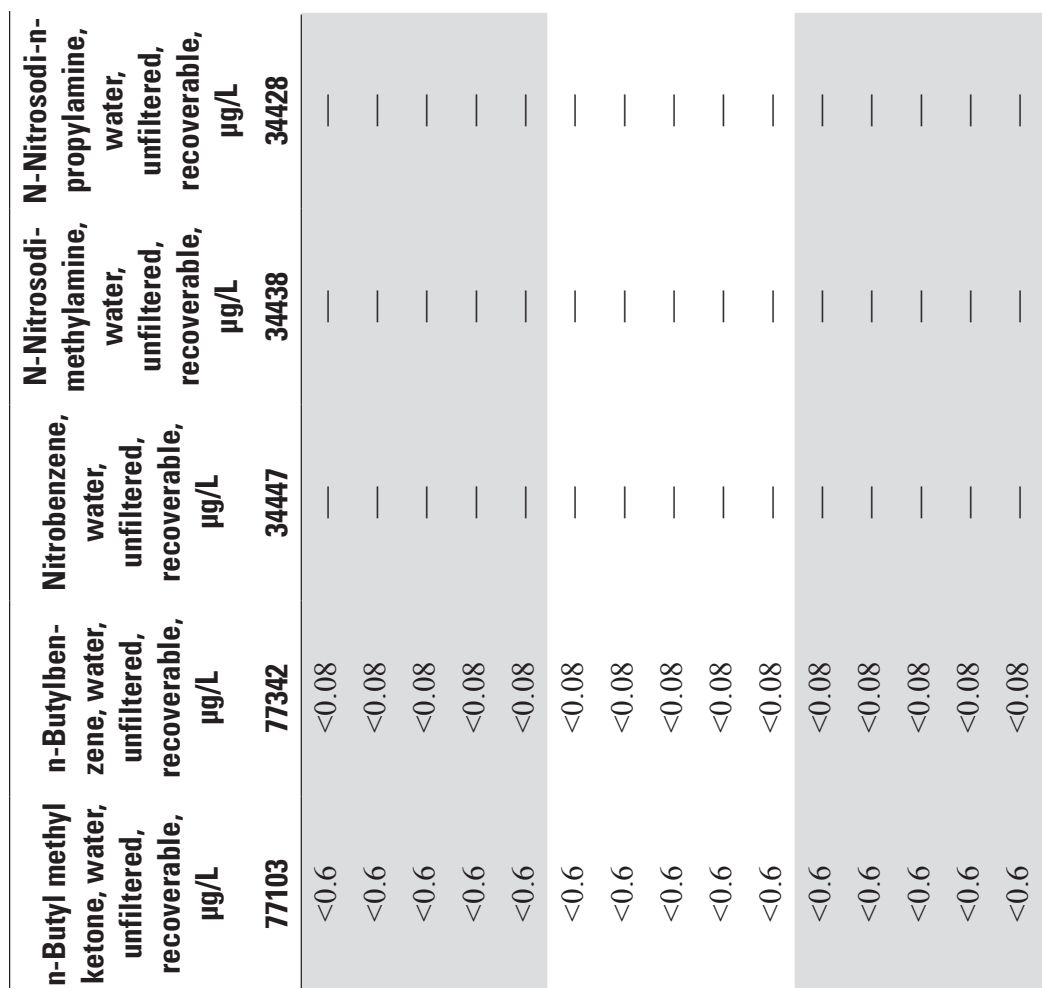

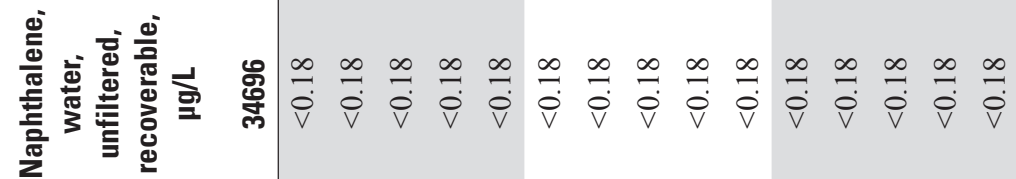

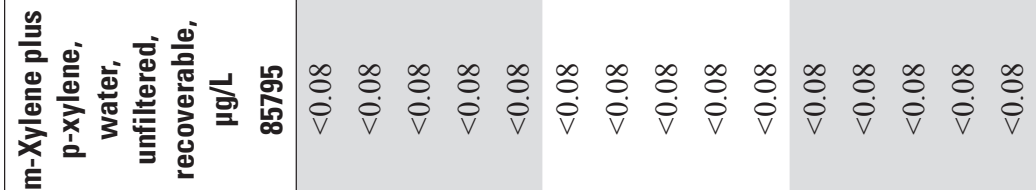

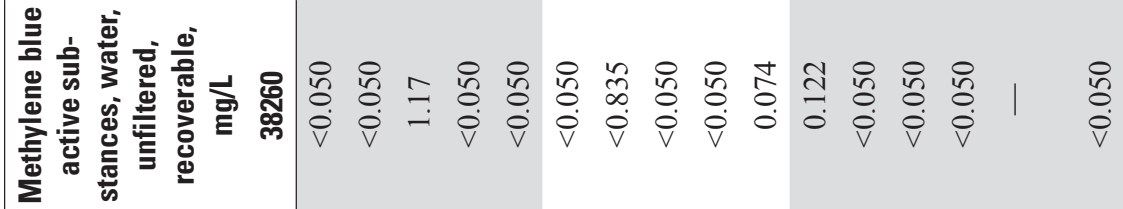

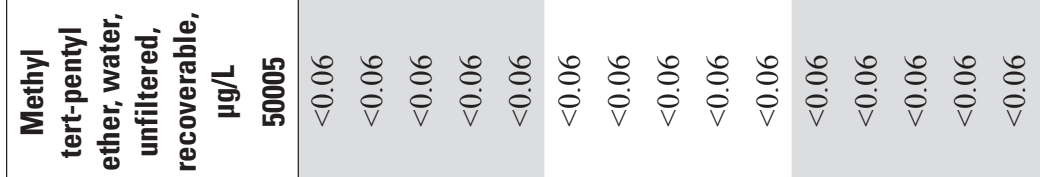

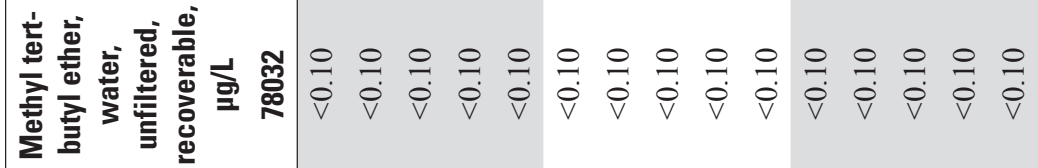

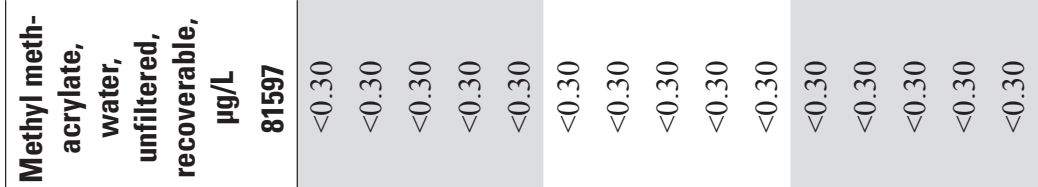
离

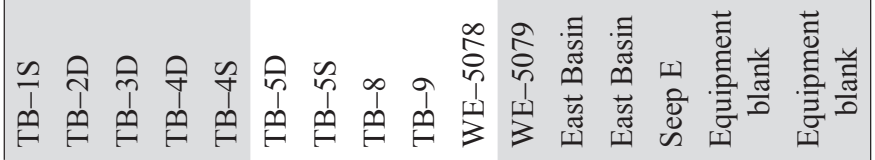




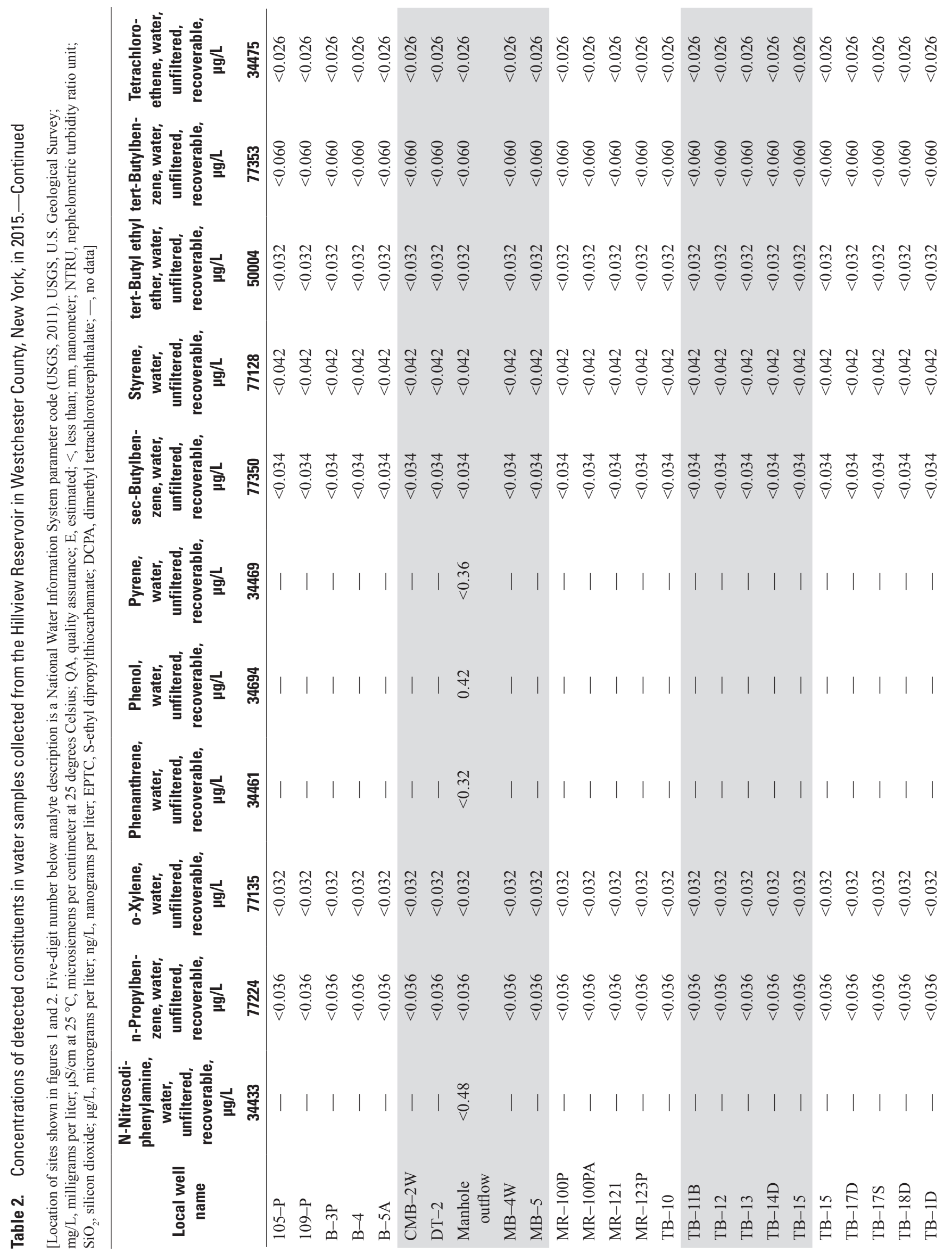


월 


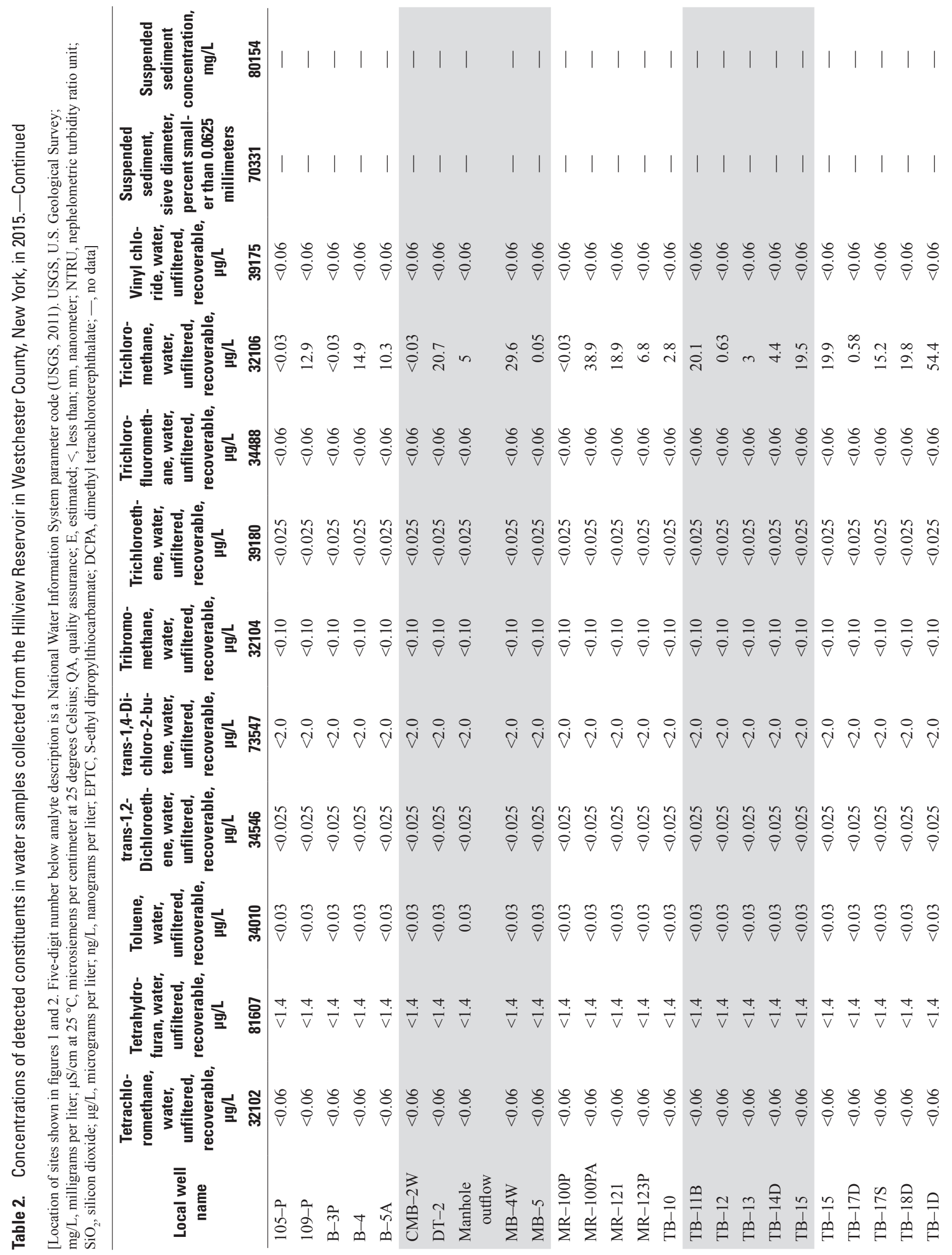



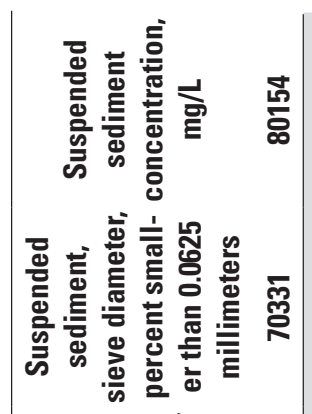

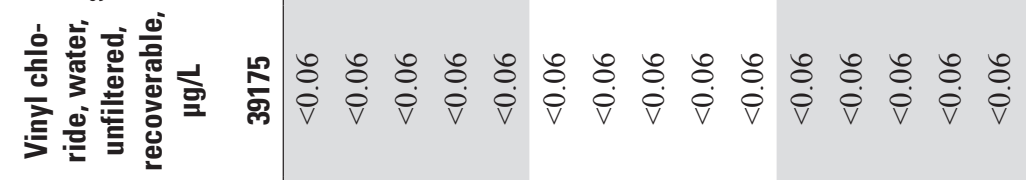

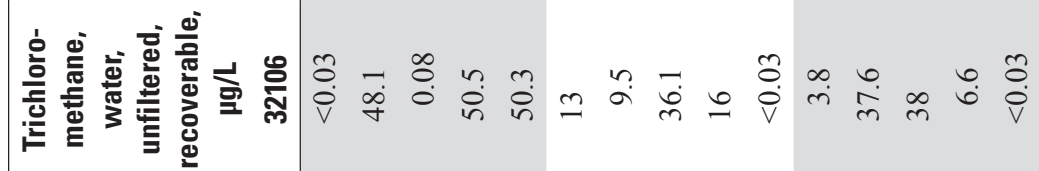

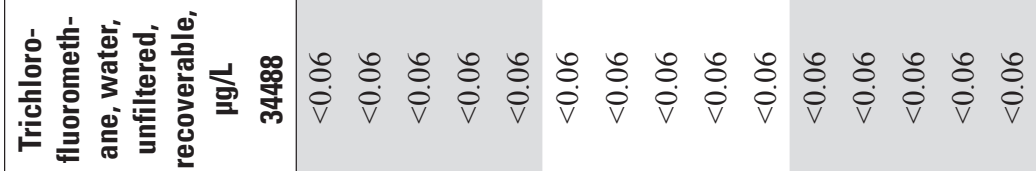

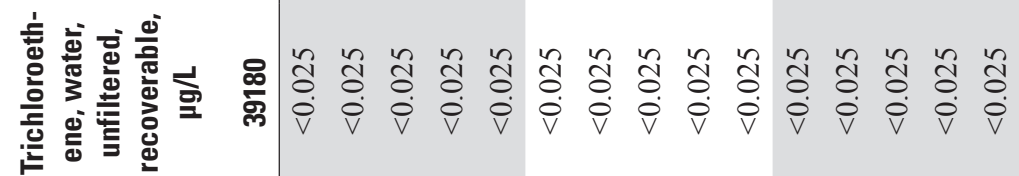

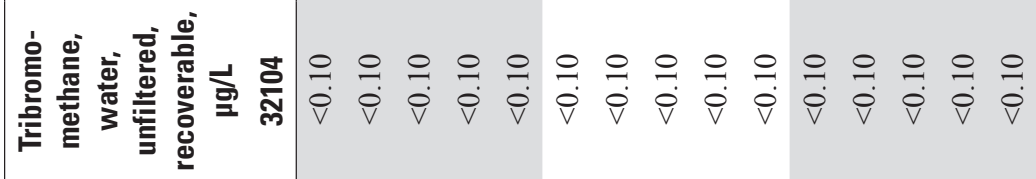
京言兽

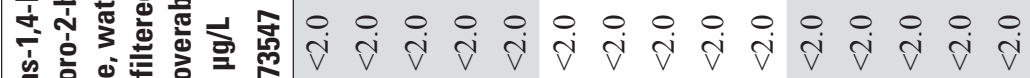

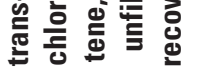

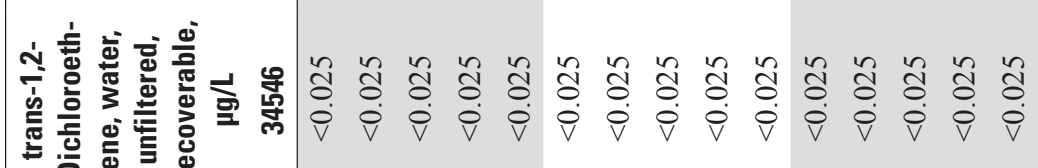

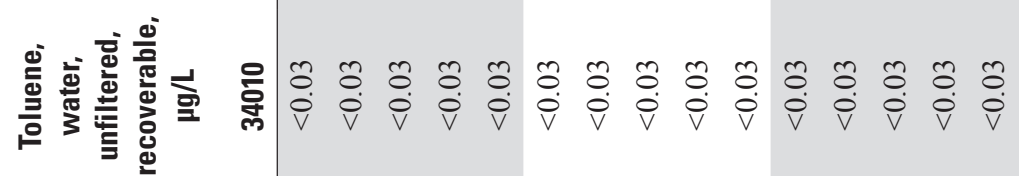

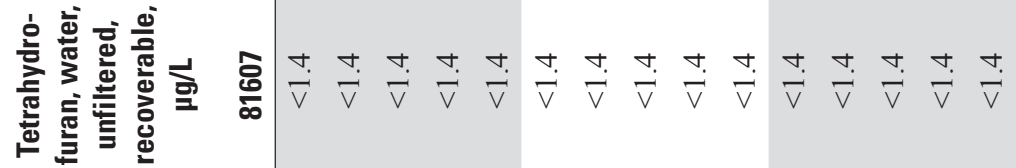

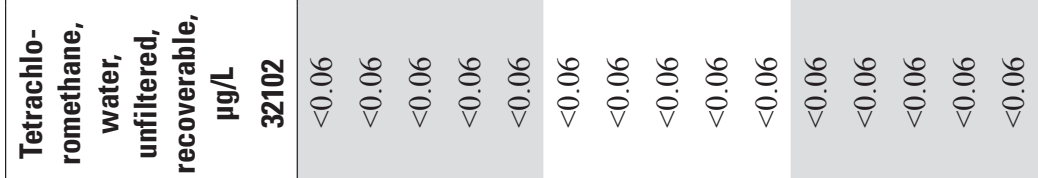
离

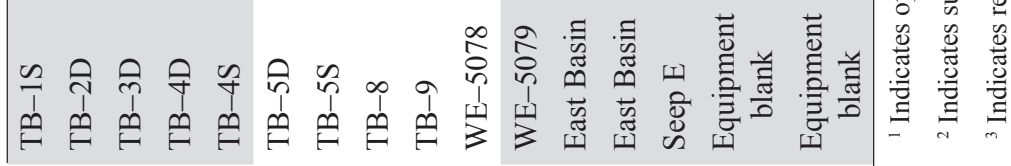



For more information about this report, contact: Director, New York Water Science Center U.S. Geological Survey

2045 Route 112, Building 4

Coram, NY 11727

dc_ny@usgs.gov

(518) 285-5602

or visit our website at https://ny.water.usgs.gov

Publishing support provided by the Pembroke Publishing Service Center 
$\stackrel{?}{\vec{E}}$

(2)

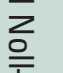

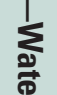

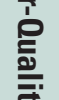

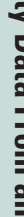

ס्ञ

岁

क्ष.

\&

言

$\sum_{\substack{0 \\ \hline}}$

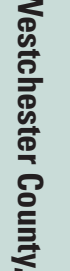

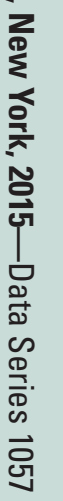

I S B N 978-1-4113-4179-1 